\title{
VIDA-statusrapport 3
}
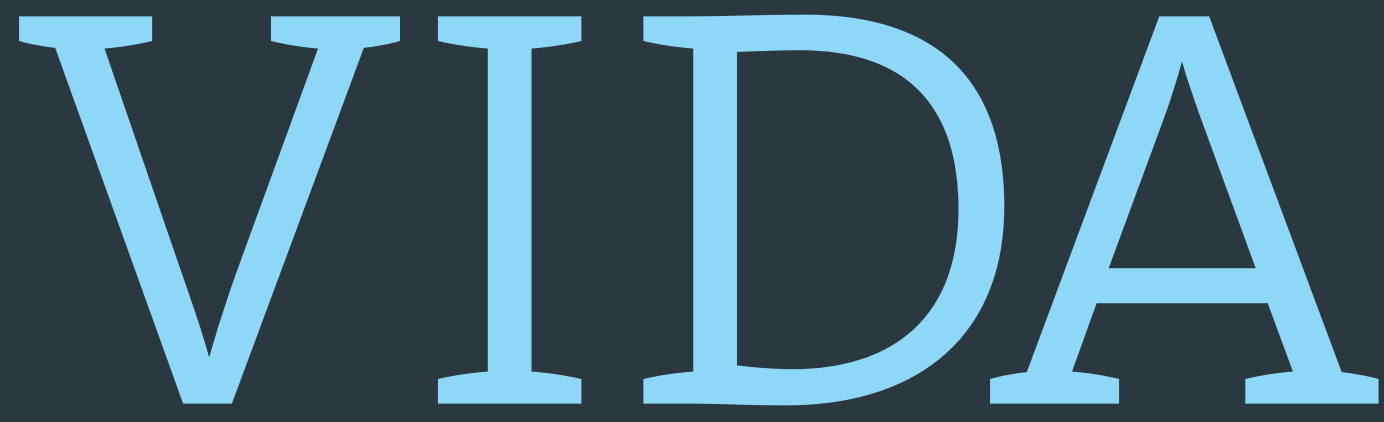

Vidensbaseret indsats over for udsatte børn i dagtilbud - modelprogram Midtvejsanalyser

Bente Jensen (red.) 
VIDA-forskningsserien 2012:01

VIDA STATUSRAPPORT 3

\section{VIDENSBASERET INDSATS OVER FOR UDSATTE BØRN I DAGTILBUD}

- MODELPROGRAM

MIDTVEJSANALYSER

BENTE JENSEN (red.) 


\section{Vidensbaseret indsats over for udsatte børn i dagtilbud MODELPROGRAM - MIDTVEJSANALYSER \\ VIDA Statusrapport 3 \\ VIDA-forskningsserien 2012:01}

ISSN 1904-8521 (Web-udgave)

ISSN 1904-8947 (Print-udgave)

(C) 2012 by VIDA-projektet

\section{Reviewgruppe}

Professor Dorthe Bleses, Institut for Sprog og Kommunikation, Syddansk Universitet

Professor Kenneth Mølbjerg Jørgensen, Institut for Læring og Filosofi (SAMF), Aalborg Universitet

Professor Mads Meier Jæger, Center for Grundskoleforskning, Aarhus Universitet

Senior Researcher Mogens Christoffersen, SFI - Det Nationale Center for Velfærd

Senior Consultant and associate professor Sven Bremberg, Child and Adolescent Public Health, Swedish

National Institute of Public Health and Department of Public Health, Karolinska Institute, Stockholm

Professor emeritus Sven Erik Nordenbo

\section{Forfattere}

Bente Jensen (red.)

Denne rapport citeres som: Jensen, B., Brandi, U., Kousholt, D., Berliner, P., Holm, A., Steiner Rasmussen, O., Stougaard, K., Kristoffersen, K., Nielsen, M., Rasmussen, M.K., Ravn, I., Friis-Hansen, M. (2012). Vidensbaseret indsats over for udsatte børn i dagtilbud - modelprogram. Statusrapport 3. Modelprogram - Midtvejsanalyser. I: VIDA-forskningsserien 2012:01, IUP, Aarhus Universitet

Grafisk design: Leif Glud Holm

Grafisk produktion: Dafolo A/S, Frederikshavn

Udgivet: Maj 2012

ISBN: 978-87-7281-722-4

DOI: $10.7146 /$ aul. 72.43

Institut for Uddannelse og Pædagogik, Aarhus Universitet

Tuborgvej 164

2400 København NV

Telefon: 87161300

http://edu.au.dk/en/research/research-projects/vida/

Bente Jensen - bj@dpu.dk

VIDA's publikationer kan frit citeres med tydelig angivelse af kilden.

Skrifter, der omtaler, anmelder, henviser til eller gengiver VIDA's publikationer, bedes sendt til VIDA. IUP, Aarhus Universitet 


\section{INDHOLD}

FORORD

RESUMÉ

$1 \quad$ INTRODUKTION 15

$\begin{array}{lll}1.1 & \text { Baggrund og formål } & 15\end{array}$

1.2 VIDA - en innovativ tilgang til indsatser i dagtilbud 16

$\begin{array}{lll}1.3 & \text { Status midtvejs i VIDA-projektet } & 19\end{array}$

1.4 Rapportens formål og opbygning 22

2 FASE 1 FRA VIDA-UDDANNELSE TIL IMPLEMENTERING I PRAKSIS

2.1 Indledning 25

2.2 VIDA uddannelsen og didaktiske overvejelser 26

$\begin{array}{lll}2.3 & \text { Indholdet fordelt på de syv uddannelsesdage } & 28\end{array}$

$2.4 \quad$ Værktøjer til refleksion og udveksling af viden og erfaringer 31

2.5 Afslutning og perspektivering 34

3 LEDERKURSER I FACILITERING: HVORDAN LEDERE STIMULERER $\begin{array}{ll}\text { ENGAGEMENT OG INNOVATION PÅ MøDER } & 37\end{array}$

$\begin{array}{lll}3.1 & \text { Udfordringen } & 37\end{array}$

$\begin{array}{lll}3.2 & \text { Transfer, forankring og ledelse af kommunikation på møder } & 37\end{array}$

3.3 Facilitering som ledelsesværktøj 39

3.4 Træning i facilitering: Pædagogiske principper og tilrettelæggelse 40

3.5 Perspektivering 43

4 LEDERES BESKRIVELSER AF FORANDRINGSPROCESSER I DET SAMLEDE DAGTILBUD - I ET PERSPEKTIV OM ORGANISATORISK LAERING

$\begin{array}{lll}4.1 & \text { Indledning } & 45\end{array}$

4.2 Lederens arbejde med viden og læring $\quad 48$

4.3 Eksisterende pædagogiske praksisser og faktorer af betydning 64

4.4 Opsamling og konklusion 80 
5 FORALDREINDDRAGELSE I VIDA

$\begin{array}{lll}5.1 & 85\end{array}$

5.2 Tilrettelæggelse og forældreinddragelse i dagtilbuddet 92

5.3 Forældreinddragelse om arbejdet med udsatte børn 95

$\begin{array}{lll}5.4 & \text { Udfordringer i forhold til forældreinddragelsen } & 99\end{array}$

5.5 Muligheder i forældreinddragelsen i forhold til arbejdet med udsatte børn 105

$\begin{array}{lll}5.6 & \text { Opsamling og konklusion } & 109\end{array}$

6 SAMMENHENGEN MELLEM DE ENKELT BØRNS KOMPETENCER OG BØRNEGRUPPENS SAMMENSATNING 113

$\begin{array}{lll}6.1 & \text { Indledning } & 113\end{array}$

$\begin{array}{llr}6.2 & \text { Statistisk analyse } & 115\end{array}$

$\begin{array}{llr}6.3 & \text { Diskussion } & 122\end{array}$

7 VIDA MIDTVEJSANALYSER - EN KONKLUSION 123

$\begin{array}{ll}\text { BILAG } & 133\end{array}$

Bilag 1 Materiale til kapitel 4, afsnit 4.2 133

Bilag 2 Medarbejder interaktion og netværk 136

Bilag 3 Fremmende og hæmmende faktorer $\quad 137$

$\begin{array}{lr}\text { REFERENCER } & 141\end{array}$

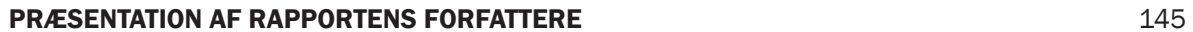




\section{FORORD}

Denne VIDA-statusrapport 3 præsenterer VIDA-projektets (Vidensbaseret indsats over for udsatte børn i dagtilbud) erfaringer og resultater fra analyser midtvejs i projektet. Projektet belyser overordnet spørgsmålet: Hvordan tager vi i dagtilbuddene bedst hånd om socialt udsatte børn?

Det omfattende projekt er bestilt og finansieret af Ministeriet for B $\varnothing$ rn og Undervisning tidligere Socialministeriet og udviklet af forskere ved Institut for Uddannelse og Pædagogik, Aarhus Universitet. Projektet skal udvikle og afprøve samt dokumentere hvilke pædagogiske indsatser i dagtilbud, der kan sikre udsatte børn en bedre tilværelse her og nu og på længere sigt. I én gruppe af dagtilbud vil der være fokus på børns trivsel og læring gennem inklusion (VIDA-Basis). I en anden gruppe vil der være fokus på børns trivsel og læring gennem inklusion (som i gruppe et) og desuden indgår forældreinddragelse (VIDA-Basis + ). En tredje gruppe dagtilbud vil have almindelig praksis (Kontrolgruppe). I et tidligere gennemf $\varnothing$ rt HPA-projekt (Jensen et al., 2009) har vi påvist, at denne form for interventionsprogram i dagtilbud har positive effekter (Jensen et al., 2011), når hele programmet omsættes som et samlet system med lokal tilpasning. VIDAprojektet er blevet til med afsæt i international forskning, der viser, at kvalitet i den tidlige indsats i dagtilbud fremmer udsatte børns livschancer, og i positive erfaringer fra HPA-projektet med at uddanne pædagogiske medarbejdere til at implementere nye former for kvalitet.

Med VIDA videreudvikles indsatsen bl.a. med supplement af mere intensive uddannelsesforl $\varnothing \mathrm{b}$ med fokus på organisatorisk læring i det samlede dagtilbud og et VIDA-forældreinddragelsesprogram (VIDA-Basis +), som baseres på nyeste viden fra et review over international forskning om effektive forældreprogrammer. Sidstnævnte forskning giver nemlig løfterige resultater om, hvad der kan opnås ved at kombinere dagtilbuddets indsats med en forældreindsats (Søgaard Larsen et al., 2012). 
VIDA-statusrapport 3, Midtvejsanalyser, kan læses som en selvstændig rapport, men flere pointer, begreber og dybtgående beskrivelser af deltagere, metoder og materialer vil kunne findes i projektets tidligere rapporter: Statusrapport 1, som introducerer VIDA-projektets design og metode (Jensen et al., 2011a) og Statusrapport 2, som præsenterer VIDA-projektets første analyser, baseline (Jensen et al., 2011b).

De dagtilbud, der indgår i VIDA-projektet, er institutioner for 3-6-årige udvalgt i de fire kommuner: Randers, Horsens, Gentofte og Brøndby. Vuggestuer og dagplejen falder således uden for VIDA. Dette valg er truffet med henblik på at udvikle viden om effekter af en målrettet udvikling af kvalitet i indsatsen for en bestemt børnegruppe. Resultater, der opnås i VIDA, vil imidlertid kunne implementeres i en endnu tidligere indsats for de 0-3-årige under hensyntagen til nødvendige justeringer, der i så fald måtte foretages i relation til bl.a. viden om de yngste børns behov, forudsætninger for deres læring og udvikling samt det forhold, at vuggestuen eller dagplejen udgør en helt anden pædagogisk kontekst. I rapporten anvendes begrebet dagtilbud som en samlet betegnelse for de enheder for de 3-6-årige, der indgår i projektet. I Statusrapport 1 (jf. Bilag 6) er det nærmere beskrevet, hvordan segmenteringen har fundet sted i de tre interventionstyper, der er valgt ud til at deltage i henholdsvis VIDA-Basis, VIDA-Basis + og kontrolgruppe. I Statusrapport 2 (jf. kap. 4 og 5) er segmenteringsmodellens succes præsenteret.

Projektets styregruppe ved Christina Barfoed-Høj, Ministeriet for B $\varnothing$ rn og Undervisning, samt ekspertgruppen knyttet til VIDA-projektet (se Statusrapport 1, Bilag 1) har bidraget med nyttige, kritiske og konstruktive kommentarer til denne Statusrapport 3. Projektets følgegruppe (se Statusrapport 1, Bilag 2) har endvidere løbende bidraget med nyttige kommentarer til projektets samlede idé, indhold i statusrapporter og de indledende drøftelser af effektforskningen.

Statusrapport 3 er udformet som en antologi, hvor medlemmer af projektgruppen hver især er ansvarlig for deres del af rapporten. Således er Bente Jensen ansvarlig for kapitel 1, og Ove Steiner Rasmussen er som koordinator for UC-gruppen ansvarlig for kapitel 2 om VIDA-uddannelsens første fase. Ib Ravn er ansvarlig for kapitel 3 om faciliteringskurser, og Ulrik Brandi og Bente Jensen er ansvarlige for kapitel 4 om analyser af interview med dagtilbudsledere om den eksisterende praksis for børn og med hensyn til læring i medarbejdergruppen. Peter Berliner og Dorte Kousholt (DPU) er ansvarlige for analyserne af forældreinddragelse, der præsenteres i kapitel 5. Endelig er Anders Holm ansvarlig for kapitel 6 assisteret af forskningsassistent Mette Friis-Hansen. Rapportens samlede opbygning, afslutning og $\varnothing$ vrige afsnit er projektleder Bente Jensen ansvarlig for. 
De 120 dagtilbud, ledere og medarbejdere, børn og forældre, der deltager i enten VIDA-Basis-, VIDA-Basis +- eller kontroldagtilbud, samt direkt $\varnothing$ rer, ledere og konsulenter i de fire kommuner takkes for deres aktive deltagelse. Kun derved bliver det muligt at opnå den fremdrift, som projektet lægger op til, og som har vist sig gældende både i første del af projektet i både uddannelses-, implementerings- og forskningsdelen (2010-11) og nu fortsat i anden del af forl $\varnothing$ bet frem mod midtstatus (2011-2012).

Korrektur er udført af Kirsten Kovacs og sproglig bearbejdning af Jakob HaahrPedersen. Rapporten er redigeret af lektor, ph.d. Bente Jensen.

København, april 2012

\section{Bente Jensen}

Lektor, ph.d., projektleder

Institut for Uddannelse og Pædagogik, Aarhus Universitet. 
VIDENSBASERET INDSATS OVER FOR UDSATTE BøRN I DAGTILBUD 


\section{RESUMÉ}

I denne statusrapport 3 om projektet VIDA: "Vidensbaseret indsats over for udsatte børn i dagtilbud - modelprogram. Midtvejsanalyser" præsenteres projektets progression og status. For det første præsenteres VIDA-uddannelsesforl $\varnothing$ bet, som det er gennemført 2011 (kap. 2 og 3). For det andet præsenteres resultater vedrørende dagtilbudslederes oplevelser, erfaringer og forventninger til deltagelse i VIDA på et tidligt tidspunkt af projektforløbet (interview sommer 2011). Denne analyse sætter både fokus på lederes beskrivelser af arbejdet med forandringsprocesser i det samlede dagtilbud (kap. 4) og på deres beskrivelser af forældresamarbejdet (kap 5). Herefter præsenteres en analyse af, hvordan deltagende børns kompetencer knytter sig til deres sociale baggrund og andre baggrundsforhold (kap 6). Afslutningsvis opsummeres projektets forl $\varnothing \mathrm{b}$ og udfordringer, der viser sig midtvejs og de muligheder, der ligger i et nyt innovativt interventionsprogram, som VIDA repræsenterer.

\section{UDDANNELSESFORL $\varnothing B$ SOM UDGANGSPUNKT FOR IMPLEMENTERING AF VIDA I PRAKSIS}

Ledere og udvalgte medarbejdere fra de 80 dagtilbud, der er udpeget til VIDAprojektets intervention, blev indledningsvis (2011) tilbudt at deltage i VIDA-projektets uddannelsesforløb, som i projektets første fase blev afholdt hver 14. dag over fire måneder. Dagtilbud fra de fire deltagende kommuner samledes på hver deres hold, så ca. 10 institutioner fra en kommune mødtes hver 14. dag og arbejdede med den viden, som uddannelsen tilb $\phi$ d.

Det helt centrale i VIDA-uddannelsen er, at der er lagt vægt på en dynamik mellem vidensformidling, videnstilegnelse og anvendelse af viden gennem refleksion og analyser af gældende praksis, og en vigtig pointe i uddannelsesforl $\phi$ bene er i den forbindelse at bevidstg $\varnothing$ re deltagerne om dynamikken mellem den individuelle videnstilegnelse og refleksion og læring i fællesskaber, som VIDA-pro- 
jektet ser som forudsætning for at arbejde med principper om organisatorisk læring i praksis. En af VIDA-programmets målsætninger er, at den tilegnede viden skal anvendes, og et succeskriterium er, at denne viden bliver en del af det fælles videnslager i den samlede organisation. VIDA-uddannelsen lægger op til, at deltagerne går tilbage til dagtilbuddet og implementerer VIDA-ideen og de konkrete retningslinjer som er udformet som VIDA-Guidelines til forbedringer af praksis (se Statusrapport 1, bilag 5). Foruden dette tilbyder VIDA-uddannelsen også kurser for ledere, som indeholder metoder til at skabe engagement og innovation på møder i det samlede dagtilbud.

\section{KURSER FOR LEDERE I FACILITERING AF LÆREPROCESSER}

Alle 80 dagtilbudsledere fra VIDA-Basis- og VIDA - Basis +-dagtilbud fra de fire kommuner deltog i november-december 2011 i et træningsforl $\varnothing \mathrm{b}$ i facilitering af møder og vidensdeling. Forløbets formål var at sætte lederne bedre i stand til at informere deres medarbejdere om VIDAs vidensgrundlag og involvere deres medarbejdere i den $l \varnothing$ bende unders $\varnothing$ gelse af institutionernes praksisser og forbedringer heraf. Klassiske personalem $\varnothing$ der med envejs lederinformation, efterfulgt af timelang debat domineret af de sædvanlige få højest talende i medarbejdergruppen, er ikke en god måde at forberede organisatorisk innovation på. Træningen bestod derfor i фvelser, der hjalp lederen til at træde i karakter som processtyrer, således at informationer, drøftelser og beslutninger tog kortest muligt tid, engagerede alle medarbejderne gennem korte, afvekslende m $\varnothing$ deprocesser og skabte størst mulig værdi for de børn, for hvis skyld møder i sidste instans afholdes. VIDA-Basis +-gruppen, der inddrager forældrene i arbejdet med at skabe mere inkluderende børnefællesskaber, trænedes desuden i bedre forældrem $\varnothing$ der og -arrangementer, idet disse ofte er vanskelige at navigere og føle sig hjemme i for forældre til udsatte børn. De er selv ressourcesvage og fordrer ekstra opmærksomhed i forældrekontakten, hvis de skal inkluderes og trækkes med ind i institutionens fællesskab - hvilket kan ske gennem bedre facilitering af forældrem $\varnothing$ der.

\section{LEDERES BESKRIVELSE AF POTENTIALER FOR FORANDRINGSPROCESSER I DET SAMLEDE DAGTILBUD - I ET PERSPEKTIV OM ORGANISATORISK LFRING}

Analysen sætter fokus på, hvordan lederne i VIDA-Basis og VIDA-Basis + arbejder med at implementere ny viden i deres dagtilbud og hvilke faktorer, der har betydning for denne implementering. Samlet set beskriver lederne det konkrete arbejde med at inddrage viden og skabe læring ud fra en anvendelse af formelle 
læringsmetoder. Specielt anvendt er mødet i forskellig form efterfulgt af kursusaktivitet og læsning af faglig litteratur. Læringskonteksten fremhæves som en vigtig faktor for arbejdet med konkret inddragelse af ny viden og læring i det samlede dagtilbud, mens informelle læringsformer kun i mindre omfang opleves som en vigtig læringsmetode af informanterne. I forhold til at udvikle kvalitet i det pædagogiske arbejde tegner sig primært et billede af tre tilbagevendende tematikker, der gør sig gældende. Den ene tematik handler om den strategiske adfærd, den anden tematik handler om graden af sammensathed i informanternes opfattelse af, hvordan de arbejder med at skabe udvikling i deres dagtilbud, og endelig retter tredje tematik fokus mod lederens rolle som supervisor eller sparringspartner.

I forhold til afdækningen af de pædagogiske praksisser ser vi tre grundlæggende pædagogiske praksisser i datamaterialet. Den første er en teoribaseret tilgang, som er karakteriseret ved, at ledere og dagtilbud arbejder målrettet og systematisk ud fra et vidensgrundlag i forhold til arbejdet med børnenes læring. Institutioner under denne grundform er præget af $h \varnothing j$ grad af organisering og struktur i hverdagen, og der tales om forskellige, bevidste pædagogiske valg. Den anden pædagogiske praksis er en erfaringsbaseret tilgang, som er kendetegnet ved, at praksis bygger videre på, hvad der plejer at fungere i praksis, og at personalet samarbejder om tilrettelæggelse og gennemf $\varnothing$ relse af pædagogiske aktiviteter. Den tredje type af pædagogisk praksis er en behovsbaseret tilgang, som også er karakteriseret ved vaner - en rutinepræget praksis-form. Dog er der her ikke stor tro på, at det at ændre praksis kan gennemf $\varnothing$ res, idet informanterne her ofte oplever rutinerne som ikke-foranderlige.

Sammenfattende peger analysen, der er baseret på data indhentet ved interview sommeren 2011, på, at VIDA-projektets perspektiv på organisatorisk læring, som læring der skal foregå ved, at alle medarbejdere i det samlede dagtilbud involveres, var en stor udfordring for mange af dagtilbuddene i udgangspunktet. Arbejdet med at forpligte sig på og konkret organisere, at det samlede dagtilbud tilegner sig ny forskningsbaseret viden, inddrager egen erfaringsbaserede viden og omsætter de to vidensformer i innovative strategier i praksis, er netop det, VIDA satte i gang gennem uddannelsen i 2011. Midtvejsanalysen vidner om, at dette for mange er nytænkende og krævende - men også om, at interessen og motivationen er til stede. Opfølgende casestudier (marts 2012), feltstudier og interview med leder og medarbejdergrupper bidrager til indsigt $i$, at dagtilbuddene arbejder målrettet og systematisk med at få VIDAs perspektiver og hele ide om organisatorisk læring implementeret. Diversitet i dagtilbuddene indebærer, at 
processer finder sted med forskelligt tempo og udbytte, men processen er sat $\mathrm{i}$ gang, og alle medarbejdere $\varsigma \varnothing$ ges involveret.

\section{FORÆLDREINDDRAGELSE}

I unders $\varnothing$ gelsen tegner der sig et klart billede af, hvorledes forældreinddragelse generelt bliver opfattet af institutionerne. Det vigtigste i forældresamarbejdet er den åbne, respektfulde og løsningsorienterede dialog. Dialogen ses som vigtig, fordi der er sider af barnets liv, som ikke ses fra henholdsvis institutionens og forældrenes side. Institutionen ser ikke, hvordan barn og forældre fungerer sammen i familien - og forældre ser ikke barnets sociale liv og udvikling i institutionen. Der er et klart fokus på daginstitutionens muligheder for at bidrage til at opbygge et forældrefællesskab, der er inkluderende og anerkendende.

Ud over dette opfattes samarbejdet med de udsatte børns forældre som et anliggende for institutionens medarbejdere sammen med andre professionelle i de tværfaglige netværk. Dette sker gennem $\emptyset$ get opmærksomhed og endnu mere dialog end med de $\varnothing$ vrige forældre. Den anerkendende og løsningsorienterede dialog kan i denne sammenhæng være en stor udfordring for både forældrene og medarbejderne. Medarbejderne kan have svært ved at fastholde denne form for dialog og i stedet blive problemfokuserede i deres samtaler omkring disse børn og familier, mens forældrene kan trække sig helt fra dialogen.

Dette fokus på dialog i forældreinddragelsen åbner for en videre refleksion over, hvad en dialog i det hele taget er, og hvad der specielt kendetegner den styrkende og løsningsorienterede dialog i forhold til forældreinddragelse i relation til indsatsen for udsatte børn. Mange af de deltagende institutioner ser en udviklingsmulighed i at styrke de udsatte børns forældre i det almene forældresamarbejde og derved skabe en inklusionsproces dér, der lфber som en fælles, men parallel proces i forhold til inklusionen af de udsatte børn i børnefællesskabet i institutionen. At skabe muligheder for dette ses som en udviklingsmulighed i forældresamarbejdet omkring udsatte børn med henblik på at skabe gode muligheder for sund kognitiv, social og emotionel udvikling for alle børnene.

\section{SAMMENHÆNGEN MELLEM DE ENKELTE B $\emptyset$ RNS KOMPETENCER OG BØRNEGRUPPENS SAMMENSÆTNING}

Analyser af sammenhængen mellem børnegruppens sammensætning i den enkelte institution, og hvordan de enkelte børn klarer sig, bliver målt på forskellige domæner i den såkaldte Strengths and Difficulties Questionnaires (SDO-). SDO 
måler børnenes socio-emotionelle kompetencer og er beskrevet grundigt i VIDAstatusrapport 1. Der er mange grunde til at tro, at børnesammensætningen i den enkelte institution kan spille en rolle for udviklingen af det enkelte barns kompetencer. For det første kan man forestille sig, at børnene påvirker hinanden. Hvis barnet er sammen med andre, velfungerende børn, styrkes dets kompetencer. For det andet kan man forestille sig, at jo flere velfungerende børn der er i institutionen, jo bedre kan personalet bruge deres ressourcer til at styrke kompetencerne hos det enkelte barn. Endelig kan man forestille sig, at børn med mange kompetencer har en tendens til at klumpe sig sammen i de samme institutioner. Analysen kan ikke adskille de tre forklaringer fra hinanden, men kan dog påvise, at der er en sammenhæng mellem det enkelte barns kompetencer og uddannelsesniveauet blandt de andre børns mødre. Andelen af piger, små børn og børn fra etniske minoriteter ser ikke ud til at spille nogen rolle i forhold til børnenes kompetencer. 
VIDENSBASERET INDSATS OVER FOR UDSATTE BøRN I DAGTILBUD 


\title{
KAPITEL 1
}

\section{INTRODUKTION}

\author{
Bente Jensen
}

\subsection{BAGGRUND OG FORMÅL}

Formålet med VIDA-projektet er som beskrevet i tidligere VIDA statusrapporter 1 og 2 (Jensen et al., 2011a, b) overordnet at unders $\varnothing$ ge effekter af en tidlig indsats i dagtilbud, der sigter mod at fremme udsatte børns trivsel, læring og udvikling gennem en inkluderende pædagogik.

Udsatte børn defineres her som børn med 'stor' sandsynlighed for en børnesag baseret på socio $\varnothing$ konomiske prædiktorer. Vi ved fra uddannelses- og socialforskning, at udsatte børn har forringede livschancer i skolen og senere uddannelse og samfundsliv. Vi ved også, at udsatheden starter allerede i børnehaven, hvilket vil sige, at en opvækst under socialt vanskelige vilkår indebærer, at visse børnegrupper er særligt udsatte for negative følgevirkninger, både personligt og socialt.

VIDA-projektet vedrører således en vigtig samfundsmæssig problemstilling. Projektets hensigt er på forskningsniveau at udvikle, afprøve og effektvurdere to forskellige modeller for tidlig indsats: VIDA-modelprogram (VIDA-Basis) og VIDA-forældreprogram (VIDA-Basis +) i dagtilbud. Det overordnede mål er at bidrage til, at kommuner og dagtilbud i højere grad i fremtiden får mulighed for at kvalificere arbejdet med socialt udsatte børn ud fra relevant viden og systematiske, målrettede metoder for arbejdet med nye praksisformer baseret på denne viden. Hele spørgsmålet om at sætte viden i spil, dvs. at arbejde vidensbaseret med henblik på at forny og forbedre praksis, er VIDA-projektets centrale omdrejningspunkt. VIDA-interventionen er derfor bygget op om et uddannelses- og implementeringsprogram, som skal kvalificere professionelles arbejde med den tidlige indsats i dagtilbud gennem $\varnothing$ get viden om børns læring og trivsel gennem inklusion og med at arbejde målrettet og bevidst med implementering af indsatsen i det samlede dagtilbud. 
De uddannelsesmæssige aspekter af interventionen består i at uddanne og træne pædagogers og lederes kompetencer til implementering af indsatsen på måder, som bidrager til fornyelse (innovation) i det aktuelle dagtilbud, dvs. på måder, der tager højde for dagtilbuddets udgangspunkt mht. bl.a. børnesammensætning og dagtilbuddets særlige muligheder og erfaringer. Dette innovative perspektiv uddybes og nuanceres efterfølgende.

\subsection{VIDA - EN INNOVATIV TILGANG TIL INDSATSER I DAGTILBUD}

International forskning giver som tidligere skitseret (Jensen et al., 2011a, kap. 1) vigtig viden om faktorer af betydning for at opnå positive effekter af tidlige indsatser i dagtilbud for socialt udsatte børn. Denne indsats må imidlertid tilpasses en dansk kontekst, da indsatsen her skal implementeres i almendagtilbud, hvor >90\% af alle 3-6-årige børn deltager.

Et internationalt program som fx Perry Preschool (Heckman et al., 2010; Heckman, 2008) omfattede ganske få børn, og indsatsen blev gennemf $\varnothing$ rt af personale uddannet specifikt til opgaven. Andre programmer, som er udviklet i nyere tid, er også udført med en specifik metode og af personale specifikt uddannet til den specifikke opgave, som omsættes med succes i udvalgte dagtilbud (Søgaard Larsen et al., 2011). Om disse former for programmer vil virke i stor skala, dvs. i almene dagtilbud, og udført af dagtilbuddet under de vilkår, der hersker, er der stadig ikke forskningsbaseret viden om.

OECD konkluderer baseret på $\varnothing$ konomiske cost-benefit analyser i sin nyeste rapport, at det kan betale sig at investere massivt i daginstitutioner, og lægger derved op til, at der er behov for at udvikle og unders $\varnothing$ ge dagtilbuds muligheder mere detaljeret end hidtil (OECD, 2012).

Det helt store spørgsmål i en dansk og nordisk kontekst er imidlertid, hvorvidt almendagtilbuddet som samlet strategi kan bidrage til at modvirke social ulighed. Endvidere er det interessant at unders $\varnothing$ ge, hvordan dagtilbud i Europa kan udvikles, så de reelt bliver en samfundsmæssig satsning rettet imod dette sociale problem. Hvis velkendte indsatser skal kunne omsættes i denne europæiske kontekst, så må de undersøges ud fra spørgsmålet, om de kan omsættes i stor skala og dermed også medtænke social inklusion som en del af indsatsen. Endelig er der også behov for at undersøge betydningen af kvalitet i dagtilbud og tænke indsatsen i dagtilbud 'forfra' ud fra de internationalt påviste kvalitetskriterier, som både drejer sig om rammer, strukturer, organisering og om processer, rela- 
tioner og de voksnes systematiske identifikation af det enkelte barns udvikling og udviklingsproces (Nielsen \& Christoffersen, 2009).

En ny unders $\varnothing$ gelse af børns færdigheder og kompetencer målt på PISA sammenholdt med førskoletilbud i en række OECD-lande påpeger, at selv om der er førskoletilbud til næsten alle børn i Danmark, kan der ikke umiddelbart konstateres bedre resultater målt på PISA. Forskerne bag unders $\varnothing$ gelsen konkluderer, at det at have universaldagtilbud for alle børn, ikke er nogen garanti for, at socialt udsatte børns kompetencer styrkes, og at social ulighed derved mindskes (Green \& Mostafa, 2011). Dette resultat underst $\varnothing$ tter en pointe, som også er fremhævet i international litteratur (Sylva et al., 2011), at det ikke er dagtilbudsdeltagelse i sig selv, der gør en forskel, men derimod at dagtilbud, der er karakteriseret som højkvalitetsdagtilbud, kan opnå positive resultater med hensyn til at styrke socialt udsatte børns alsidige udvikling og dette 'med langtidseffekter. Nielsen \& Christoffersen (2009) præsenterer en indkredsning af, hvad forskningsoversigter har peget på, der skal til, for at dagtilbud kan gøre en positiv forskel, og som vist i VIDA-statusrapport 1 (Jensen et al., 2011a, kap. 1) er en række parametre vigtige i den forbindelse. Sådanne parametre er netop indbygget i det program, som VIDA-projektet bygger på, og de er uddybet både i tidligere statusrapporter og i de retningslinjer, der er udviklet til programmet (Ibid., Bilag 5). Opgaven bliver nu at unders $\varnothing$ ge hele situationen og begrebet kvalitet i dagtilbud nærmere, herunder dagtilbuddenes forudsætninger for at implementere målrettede og systematiske indsatser, som er baseret på forskningsbaseret viden om, hvad der virker, og retningslinjer for at anvende denne viden i dagligdagens pædagogik.

Det er dette fundament, VIDA-projektets samlede bestræbelse på at styrke udsatte børns livschancer bygger på. I VIDA-projektet tager indsatsen udgangspunkt i tre perspektiver ved højkvalitetsdagtilbud:

- Første perspektiv drejer sig om en systematisk, målrettet og fokuseret indsats baseret på viden om, hvad der virker, og hvad børn, især socialt udsatte børn, har brug for og ret til. Det indebærer en tidlig målrettet indsats, der sætter fokus på alle børns ressourcer, men med særligt fokus på socialt udsatte børns ressourcer som alternativ til at tage afsæt i børns 'mangler,' 'problemadfærd' el.lign. Dette element sigter imod at identificere læringsmuligheder for alle børn fra tidligste alder.

- Andet perspektiv drejer sig om at karakterisere læringsmuligheder for alle børn. Det indebærer en forståelse af læring - ikke som noget, der passivt tilegnes - men derimod som noget, der skabes gennem aktiv og social handling. 
Børn skal lære at lære, dvs. tilbydes stimulerende læringsaktiviteter og relationer, der fremmer trivsel, engagement, nysgerrig udforsken og tænkning. Det er samspillet mellem det individuelle og det fælles, der er en væsentlig del af dette læringskompleks.

- Tredje perspektiv drejer sig om at komme fra det enkelte individ og til en samlet organisatorisk satsning. Det indebærer, at det er det samlede dagtilbud, der arbejder med børns udvikling og læring ud fra de ovennævnte og fælles perspektiver. Det samlede dagtilbud kan være kreativt skabende gennem en forpligtethed på at skabe værdifor $\varnothing$ gelse for alle børn gennem nye arbejdsformer. Det samme perspektiv gør sig gældende i den inkluderende indsats for forældre, som igangsættes i VIDA-Basis +-institutioner. Det har nemlig vist sig ifølge forskning i forældreprogrammer, som er samlet til VIDA-projektet (Søgaard Larsen et al., 2011), at forældreindsatser, der foregår uden for institutionen, ikke er effektive sammenlignet med indsatser for forældre, der integreres i institutionerne.

For at realisere disse tre perspektiver er det nødvendigt, at ledere og medarbejdere arbejder med at tænke og konkret arbejde med læring helt fra begyndelsen af børnenes institutionsliv, og det er netop det, VIDA-uddannelsen lægger op til - og træner.

Det er således en væsentlig opgave i VIDA-programmet at styrke deltagernes kompetencer til at arbejde systematisk og målrettet med børns læring og trivsel ud fra et bevidst begreb om social inklusion.

VIDA-programmets nøgleelementer kan på den baggrund opsummeres som følger:

- VIDA implementeres i almendagtilbuddet, hvilket indebærer, at indsatsen skal kunne implementeres i stor skala.

- VIDA implementeres i dagtilbud, som er udtrukket tilfældigt. Dette betyder, at de pædagogiske medarbejdere, der skal implementere indsatsen, møder projektet med forskellige forudsætninger.

- VIDA implementeres i det samlede dagtilbud, og et succeskriterium for arbejdet er, at lederes og medarbejderes læring omsættes i en samlet praksis- og organisationsudvikling.

- VIDA repræsenterer en innovativ tilgang til tidlig indsats. Dagtilbuddenes medarbejdere uddannes til at arbejde teoribaseret, målrettet og systematisk 
med et VIDA-curriculum og på den baggrund udvikle lokale eksperimenter, der tilpasses den aktuelle lokale situation.

- VIDA-uddannelsen vedrører 1) børns læring, trivsel og inklusion og 2) voksnes læring og implementering i det samlede dagtilbud. Endvidere suppleres uddannelsen med kurser i ledelsesstrategier og facilitering.

VIDA-modelprogrammet bygger således på den bagvedliggende filosofi, at det er gennem kvalificering af pædagogisk arbejde, at reel og vedvarende fornyelse (innovation) i dagtilbuddene finder sted. Den forskningsmæssige opgave i VIDA er på den baggrund at unders $\varnothing$ ge, om en innovativ tilgang, som ovenfor beskrevet, bidrager til at opnå den $\varnothing$ nskede positive effekt målt på børns udbytte.

\subsection{STATUS MIDTVEJS I VIDA-PROJEKTET}

VIDA-projektet sigter som nævnt mod at styrke kvaliteten i dagtilbud gennem uddannelse af medarbejderne. Projektet unders $\varnothing$ ger betydningen af at arbejde målrettet og systematisk med alle børns udvikling i dagtilbud og mere specifikt socialt udsatte børns udvikling (VIDA-Basis) samt betydningen af et målrettet forældresamarbejde (VIDA-Basis + ). Projektet bidrager endvidere med information om processer, der bidrager til pædagogiske medarbejderes kvalificering til at arbejde vidensbaseret og innovativt.

I det følgende præsenteres i korte træk en status på projektets forl $\varnothing b$ og progression, arbejde med viden, uddannelse og implementering samt præsentation og formidling i en række informationsbokse:

Projektforløb og progression - 2011

Deltagerne fra de fire kommuner, ca. 120 dagtilbud og 7.000 børn, har siden projektstart i februar 2011 været aktivt inddraget og arbejdet med VIDA-projektets uddannelse, omsætning i praksis og løbende planlægning, koordinering og vidensdeling på alle niveauer.

Projektets organisation i mange grupper, der samarbejder om projektet (se Jensen et al., 2011a, BILAG 3), er etableret, og funktionaliteten har vist sig ved, at planlagte forl $\varnothing \mathrm{b}$ er gennemf $\varnothing \mathrm{rt}$, og at projektet skrider frem efter angivne mål og milepæle. 
Projektforløb og progression - 2011 fortsat

De projektinterne værktøjer SharePoint (projektets digitale platform), ITrefleksionsværkt $\varnothing$ jet, Refleksionsrum, og Dialognetværk på tværs af kommuner er udviklet og fungerer her midtvejs efter hensigten som redskaber til at underst $\varnothing$ tte læreprocesser som følge af VIDA.

VIDA-uddannelsen, som varetages af undervisere ved University Colleges, og kurser i facilitering for ledere, som varetages af forskere fra AU, er gennemført med succes det første år af projektet.

L $\varnothing$ bende evalueringer har vist, at denne form for aktivt involverende tiltag for nogle dagtilbud er en stor udfordring, og for andre præcist er den form, som gør, at man som leder af et dagtilbud eller medarbejder i VIDA-dagtilbud kan se sig selv som en vigtig aktør i udvikling af kvalitet i pædagogisk praksis. Udsagn fra den dybtgående interviewunders $\varnothing$ gelse med samtlige deltagende ledere (sommer 2011) viser, at langt de fleste VIDA-deltagere ser relevansen af projektet. Dette udtrykkes ved, at deltagerne har store forventninger til, at projektet kan gøre en positiv forskel for socialt udsatte børn, og at projektets design indebærer nye muligheder for udvikling af praksis. Der er selvfølgelig nuancer og yderpunkter i form af deltagere, der mener noget andet, og deltagere, som er mindre motiverede, som vi også så det eksemplificeret i en tidligere analyse (VIDA-statusrapport 2, kap. 2).

VIDA - uddannelse og implementering 2012

Uddannelse af ledere og medarbejdere blev igangsat med en del 1 i 2011 (se kap. 2 i denne rapport) og fortsætter med del 2 og 3 i 2012.

Deltagerne uddannes til at kvalificere fornyelse af den pædagogiske praksis. Projektets perspektiver fastholdes, styrkes og implementeres gennem uddannelse i 2012, der også indebærer netværksdannelser, nye organiseringsformer samt formidling.

Uddannelsesforl $\varnothing$ b i 2012 bygges op om eksperimenterende pædagogisk udvikling, der konkret retter sig mod aktiviteter, der fremmer børns trivsel, læring og inklusion (VIDA-Basis) og nyere former for forældresamarbejde (VIDA-Basis +). Fokus rettes imod deltagernes kvalificering til at 
VIDA - uddannelse og implementering 2012 fortsat

arbejde med vidensdeling, organisatorisk læring og evaluering, herunder dokumentation af de udviklede og gennemf $\varnothing$ rte lokale eksperimenter. Udfordringer i relation til denne anden del af VIDA programmet er 1) at dagtilbuddenes har forskellige forudsætninger for at arbejde teoribaseret og læringsorienteret (som påvist i VIDA-statusrapport 2 og i denne rapport, kap. 4), 2 og 2) at høj faglighed som søges udviklet på VIDA-uddannelsen kan st $\varnothing$ de imod deltagernes oplevelse af konkrete vilkår, såsom ressourcer, deltagerforudsætninger og rammebetingelser.

VIDA-uddannelsen søger imidlertid at bygge videre på deltagerforudsætninger ved at lægge vægt på at skabe fornyelse af praksis gennem træning i konkret at opstille mål, udvikle en strategi og arbejde med eksperimenter i egne dagtilbud baseret på såvel teori- og forskningsbaseret viden som VIDA tilbyder og erfaringsbaseret viden, som deltagerne selv bringer med ind i feltet. På den måde søges dynamikken mellem retningslinjer, der er udviklet til VIDA-projektet, som er kaldt VIDA-guidelines (se VIDA-statusrapport 1, BILAG 5) og deltagernes egne forudsætninger sat i spil.

VIDA sætter viden i spil

VIDA-uddannelser for ledere og pædagoger bygges op, så det 'lærte' kommer i spil i den pædagogiske dagligdag og sættes i relation til deltagernes erfaringer og de særlige behov og problematikker, der er i børnegrup-

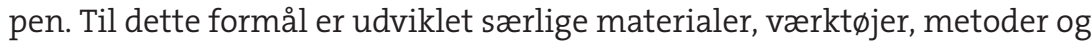
guidelines (se VIDA-statusrapport 1, kap. 2).

Værktøjer og VIDA-uddannelse er tilrettelagt, så deltagerne lærer at arbejde målrettet og systematisk med børns læring, trivsel og inklusion og at arbejde lige så systematisk med organisatorisk læring og implementering af indsatsen i det samlede dagtilbud. Kurser for ledere er tilrettelagt, så disse får værkt $\varnothing j e r$ til at kunne facilitere vidensdeling og læreprocesser i det samlede dagtilbud baseret på VIDA- programmets indhold. 


\section{Præsentation og formidling}

Præsentation og formidling af projektet foregår løbende, både gennem udgivelsen af en række rapporter og på andre måder, således at projektet undervejs udbredes til en større kreds end deltagerne i VIDA.

Projektets resultater formidles løbende i VIDA-statusrapporterne, og $\phi \mathrm{V}$ rig information kan hentes på hjemmesiden (http://edu.au.dk/forskning/ projekter/vida/).

De første rapporter i VIDA-forskningsserien udkom i 2011:

- VIDA-statusrapport 1. Design og metode. VIDA-forskningsserien 2011:01.

- Forskningskortlægning af programmer for 0-6-årige med forældreinvolvering i dagtilbud. VIDA-forskningsserien 2011:02.

- VIDA statusrapport 2: Baseline. VIDA-forskningsserien 2011:03.

I maj 2012 slår VIDA dørene op til en midtvejskonference "Social innovation i dagtilbud" (http://edu.au.dk/aktuelt/arrangement/artikel/vida-konference-social-innovation-i-daginstitutioner1)

På konferencen tegner internationale og danske forskere fra VIDA og andre milj $\phi$ er et bredt billede af den forskningsmæssige viden om, hvad der virker i arbejdet med kommuner, professionsh øjskoler, universitet samt udsatte børn og unge, og hvad der eventuelt 'modvirker'. Det tætte samarbejde med ledere og praktikere, om løbende uddannelse og evalueringer er kernen i VIDA- projektet. Derfor deltager repræsentanter fra alle dele af projektet med bidrag på workshops. Konferencen præsenterer VIDA-projektets definition af social innovation i dagtilbud som varig fornyelse af praksis med henblik på at fremme udsatte børns livschancer.

\subsection{RAPPORTENS FORMÅL OG OPBYGNING}

Denne statusrapport 3 om midtvejsanalyser præsenterer VIDA-uddannelsesforløbets f $\varnothing$ rste faser, dets opbygning og gennemf $\varnothing$ relse (kap. 2 og 3) samt analyser af interview med dagtilbudsledere om deres oplevelser, erfaringer og forventninger til deltagelse i VIDA på et tidligt tidspunkt af projektforløbet (interview sommer 2011) (kap. 4 og 5). Herefter præsenteres en analyse af, hvordan deltagende 
børns kompetencer knytter sig til deres sociale baggrund og andre baggrundsforhold. Dette som udgangspunkt for at kunne sige noget om de forudsætninger, som målgruppen for projektet, børn præget af socialt vanskelige vilkår har, og som indsatsen rettes mod (kap. 6). Endelig samles rapporten i en konklusion om, hvordan VIDA-programmet implementeres midtvejs gennem forl $\varnothing$ bet og de udfordringer og muligheder, der ligger i det design for et nyt innovativt interventionsprogram, som VIDA repræsenterer.

Rapporten har som formål at gøre status over projektet og dets delelementer midtvejs i projektet og har fokus på forhold vedrørende uddannelse og lederkurser samt analyser af dagtilbuddenes eksisterende praksis som forudsætninger for implementering af hhv. VIDA-Basis og VIDA-Basis +. Endelig præsenteres mere nuanceret analyser vedrørende deltagende 3-6-årige børns karakteristika, hvad angår kognitive og nonkognitive kompetencer knyttet til deres sociale baggrund samt børnegruppens sammensætning.

Rapportens kapitler kan således læses selvstændigt, men på samme tid hænger kapitlerne 2 og 3 samt 4 og 5 som nævnt sammen, da de to første præsenterer den samlede uddannelses faser. Disse to kapitler indeholder en del begreber og henvisninger til metoder og materialer. Disse er beskrevet nærmere tidligere, og læsere, der er interesserede i at gå i detaljer med sådanne elementer, henvises til VIDA-statusrapport 1 (Jensen et al., 2011a). På samme måde hænger kapitel 4 og 5 sammen, da de præsenterer analyser af de første kvalitative interview, der er gennemf $\varnothing$ rt med dagtilbudsledere om deres oplevelser, erfaringer og forventninger til arbejdet med at implementere VIDA-programmet på et tidligt tidspunkt i projektforl $\varnothing$ bet (interview sommer 2011) (kap 4 og 5). Første del unders $\varnothing$ ger deltagende lederes oplevelse af og forventninger til at skulle arbejde med implementering af den viden, metoder og nye måder at facilitere læring på, som uddannelsen i VIDA tilbyder (kap. 4). Anden del undersøger, hvordan forældresamarbejdet gribes an i de VIDA-Basis +-dagtilbud, der netop sætter fokus på at kombinere dagtilbudsindsatsen med forældreinddragelse (kap. 5).

Kapitel 6 præsenterer en analyse af, hvordan de deltagende børns kompetencer knytter sig til deres sociale baggrund og andre baggrundsforhold. Dette som udgangspunkt for at kunne sige noget om de forudsætninger, som målgruppen for projektet, børn præget af socialt vanskelige vilkår, har, og som er det udgangspunkt, indsatsen rettes mod. 
Afslutningsvis samles rapportens præsentationer og analyser i en konklusion om status midtvejs i VIDA-projektet med hensyn til uddannelsens intentioner, konkrete gennemf $\varnothing$ relse og analyser af deltagernes forudsætninger, som de blev ekspliciteret i interview og analyser af børnedata i 2011. 


\title{
FASE 1 FRA VIDA-UDDANNELSE TIL IMPLEMENTERING I PRAKSIS
}

\author{
Ove Steiner Rasmussen, Karen Stougaard, Kristina Kristoffersen, \\ Margit Nielsen, Mette K. Rasmussen
}

\subsection{INDLEDNING}

I dette kapitel redeg $\phi r$ undervisergruppen for arbejdet med at udvikle og tilrettelægge uddannelsesforl $\phi b$ og undervisning i fase 1. Deltagerne skal i fase 1 få indsigt i og viden om de VIDA-principper, som udgør et samlet koncept (se dette uddybet i VIDA-statusrapport 1, Jensen et al., 2011a: 31). De tre principper er: 1) fra et fejlfindings- til et ressourcesyn, 2) fra et passivt til et aktivt læringsbegreb og 3) fra et individuelt til et organisatorisk innovativt læringsperspektiv (Jensen et al., 2011 c, VIDA Kvalifikationsmappen ). Desuden skal deltagerne (Ibid.: 41): "tilegne sig viden og evner til at arbejde vidensbaseret i analyse af egen praksis" og blive i stand til "målrettet og systematisk at opstille mål og vurdere egne handlekompetencer i relation til opstillede mål for børns kompetenceudvikling". For deltagerne i VIDA-Basis + er der desuden et særligt perspektiv på inddragelse af forældre (Jensen \& Haahr-Pedersen, 2011). I fase 1 er det overordnede mål derfor aktivt at få sat viden i spil, arbejde med refleksion og handlestrategier for udvikling af praksis.

I uddannelsen deltager en leder og en pædagog fra hvert involveret dagtilbud. Deres opgave bliver efterfølgende at implementere viden fra uddannelsen i egen pædagogisk praksis. Deltagerne involveres i $\varnothing$ velser, refleksioner over teori og pædagogisk praksis og arbejde i grupper og formidling og inspireres med anvisninger på, hvordan de kan arbejde med iscenesættelse af forandringsprocessen og implementeringen i egne institutioner. Desuden præsenterer undervisningen de værkt $\varnothing j e r$, der indgår i projektet. Efter hver undervisningsgang arbejder deltagerne videre i Refleksionsrummet, hvor dagens undervisning bearbejdes og 
reflekteres. Resultatet af arbejdet i Refleksionsrummet formidler deltagerne på VIDA-projektets digitale platform SharePoint. Den overordnede planlægning og de didaktiske overvejelser gøres i fællesskab i undervisergruppen, der består af adjunkter og lektorer fra UC Syddanmark, UC Nord og UC Lillebælt.

\subsection{VIDA-UDDANNELSEN OG DIDAKTISKE OVERVEJELSER}

Formålet for uddannelsen i første fase er, at deltagerne opbygger en fælles viden om forskningsbaseret viden om udsatte børn og om forældreinddragelse:

"Intentionen bag hele uddannelsesforløbet er dels, at deltagerne på baggrund af undervisning, de indbyggede vidensbaserede materialer og udviklingsværktøjer selv sætter fokus på at udvikle viden, refleksioner og redskaber til at arbejde med deres egen praksis, og dels at deltagerne opnår viden om, hvordan evidensbaseret viden og refleksioner kan udfoldes i dagtilbuddet og danne grundlag for nye pædagogiske praksisser i organisationen på måder, som involverer alle medarbejdere" (Jensen et al., 2011a: 35).

VIDA-projektet tager afsæt i en grundlæggende antagelse om, at kvalificering af de pædagogiske medarbejdere bedst kan ske ved, at uddannelsesforl $\varnothing$ bet underst $\varnothing$ tter organisatorisk læring, ejerskab og aktivt medskabende deltagere. Uddannelsen skal 'forstyrre' og udfordre deltagernes grundlæggende opfattelser og faglige viden. Derfor er uddannelsesdagenes didaktik og arbejdsformer baseret på en $h \varnothing$ j grad af deltagerinddragelse, der giver plads til den omfattende mængde af viden, deltagerne har med sig. Viden og refleksion sættes i spil, i håb om at det kan bidrage til udviklingen af en ny, innovativ pædagogisk praksis (Statusrapport 1: 33).

Undervisningstemaerne i fase 1 er følgende:

1. Introduktion til VIDA-projektet

2. Social arv

3. Handlekompetence

4. Pædagogikkens og dagtilbuddets betydning

5. Inklusion og eksklusion i et pædagogisk perspektiv

6. VIDA-refleksionsværkt $\varnothing$ jet

7. Opsamling af viden, erfaringer, refleksioner og perspektivering. 
Alle uddannelsesdage er bygget op over en organisatorisk ramme, der ser således ud:

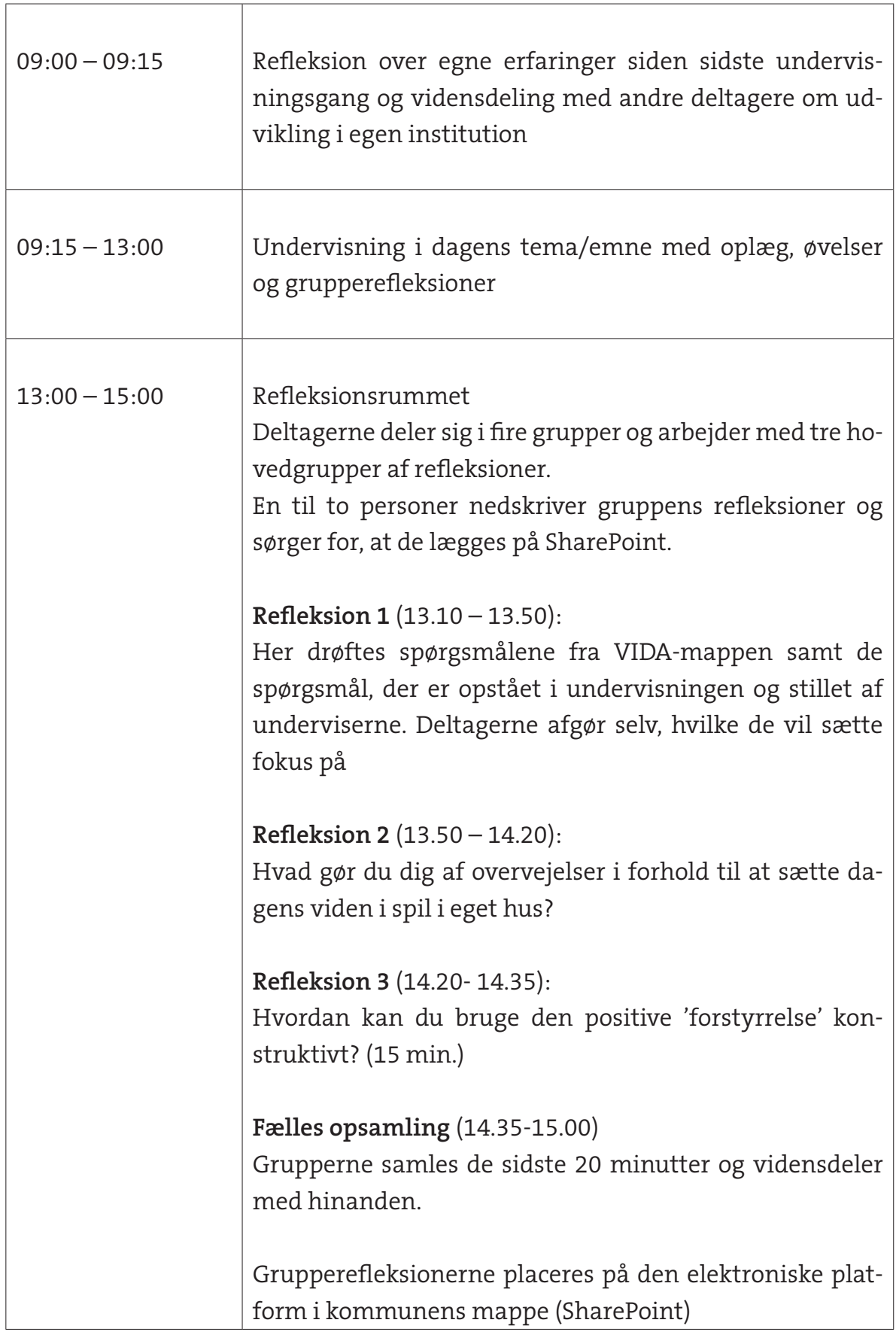


I tilrettelæggelsen og gennemførelsen af uddannelse og undervisning er der stræbt efter en ensartethed på tværs af VIDA-Basis og VIDA-Basis +. Intentionen er at kvalitetssikre projektets uddannelsesdel. Derfor er indhold, metoder, struktur og undervisere gennemgående i de enkelte indholdselementer og temaer, der indgår i uddannelsen.

I det følgende beskrives mere detaljeret de didaktiske overvejelser og valg af indhold i uddannelsesdagene.

\subsection{INDHOLD FORDELT PÅ DE SYV UDDANNELSESDAGE}

Første uddannelsesdag introduceres hele VIDA-forskningsprojektet. Der orienteres om den lovgivningsmæssige ramme eksempelvis om forpligtigelser og fortrolighed inden for projektet. Projektets tre grundlægende principper bliver sat i spil: 1) fra fejlfinding til ressourcesyn, 2) fra passivt til aktivt læringsbegreb og 3) fra individuel til organisatorisk læring. Projektets tilgang og forståelse af social udsathed defineres sammen med andre grundbegreber i projektet. Brugen af den digitale kommunikationsplatform (SharePoint) introduceres og motiveres. Denne uddannelsesdag skaber indsigt i og motivation for deltagelse i VIDA-projektet samt fors $\varnothing$ ger at skabe betingelser for, at visionen om fremme af social inklusion i dagtilbud er mulig.

Anden uddannelsesdag har som mål at bibringe kursisterne en forståelse af, at social udsathed ofte er knyttet til institutionens kultur, og at ændring af negativ social arv forudsætter en bevidstgфrelse om, at individuelle forskelle skal forstås og håndteres i forhold til den kontekst, som institutionen skaber. Deltagerne reflekterer over motiverne for, at man handler, som man gør, og hvilke konsekvenser handlingerne kan have i forhold til pædagogikken og i forhold til børnene. Pierre Bourdieus begreber om felt, distinktion, kapital og habitus introduceres. Ved hjælp af disse begreber bliver der fokuseret på forskellige paradigmer og perspektiver som fx individ og kontekst (VIDA-mappen kap. 9).

Undervisningen præsenterer to forskellige perspektiver inden for forskningen i social arv: 1) strukturperspektivet og 2) individperspektivet (VIDA-mappen kap. 8). Deltagerne forholder sig til egen praksis og finder eksempler på det, der udfordrer den bourdieuske forståelse af "kulturel træghed" i forhold til barnets muligheder. Der reflekteres over begrebet og en mulig ny forståelse af egen praksis. Spejling introduceres som redskab til at unders $\emptyset$ ge egen praksis uden at skride til $\varnothing$ jeblikkelig handling. Der redegøres for, hvordan det i VIDA-projektet er hen- 
sigten at bevæge sig væk fra stigmatiserende udpegning af risikobørn og i stedet fokusere på livschancer og handlekompetencer, og hvorledes disse kan fremmes ved pædagogisk intervention (VIDA-mappen kap. 7 og 10). På anden uddannelsesdag etableres der grundlag for at arbejde videre med begrebet resiliens, risiko- og beskyttelsesfaktorer, inkluderende og ekskluderende processer, som er indholdet i tredje uddannelsesdag.

Tredje uddannelsesdag er formålet med undervisningen at fokusere på resiliens og inkluderende pædagogik (VIDA-mappen kap. 16), således at eksklusion af børn i socialt udsatte positioner imødegås. Deltagerne på VIDA-Basis og VIDABasis + skal opnå forståelse af inklusion og få viden om eksklusionsmekanismer og styrkelse af resiliens hos børn i institutioner. For VIDA-Basis +-deltagere er formålet yderligere at skabe refleksioner over nuværende og fremtidige muligheder for forældreinddragelse i et inklusionsperspektiv.

De fem eksklusionsmekanismer (VIDA-mappen kap. 11) behandles, eksemplificeres og relateres til viden om risiko- og beskyttelsesfaktorer, og der arbejdes med, hvordan pædagogiske medarbejdere kan styrke resiliens hos dagtilbuddets børn. Forståelsen af begrebet inklusion bliver relateret til VIDA-projektets tre grundlægende principper: 1) fra fejlfinding til ressourcesyn, 2) fra passivt til aktivt læringsbegreb og 3) fra individuel til organisatorisk læring.

Forståelsen af inklusion, eksklusionsmekanismer, og hvordan pædagogiske medarbejdere kan styrke resiliens, skal fungere som et vidensbaseret og teoretisk fundament til at arbejde videre med udvikling af handlekompetencer i daginstitutioner.

Fjerde uddannelsesdag tager udgangspunkt i VIDA-mappens kapitel 4 om handlekompetencer som mål for VIDA-intervention og princippet om et ressourcesyn. Der arbejdes med relevant lovgivning. Begrebet handlekompetence introduceres, sådan som det forstås i VIDA-projektet, og der foretages en analyse, der sætter fokus på relevant lovgivning (dagtilbudsloven) og forskning.

For VIDA-Basis og VIDA-Basis + er målet, at få deltagerne til at reflektere over og blive 'forstyrret' i forhold til den måde, der arbejdes med handlekompetencer og inddrages forskning og lovgivning i det pædagogiske arbejde i institutionerne på.

Femte uddannelsesdag følger op på refleksioner og 'forstyrrelser' i forhold til deltagernes arbejde med handlekompetencer og lovgivning om det pædagogiske arbejde i egne institutioner. Det sker ved at præsentere viden om didaktik og 
kvalitet i det pædagogiske arbejde i daginstitutioner, herunder kvalitet i interventionen i daginstitutioner. Der bliver arbejdet med at formulere vidensbaserede pædagogiske principper og et handlekompetenceperspektiv, der må tages i anvendelse ved udarbejdelse af pædagogisk intervention over for socialt udsatte børn (VIDA-mappen kap. 14-15) samt resultater fra vidensopsamling fra SFI (Nielsen \& Nygaard Christoffersen, 2009).

Undervisningen skal fremme refleksioner over forskellige pædagogiske principper for den gode praksis, samt den betydning, handlekompetencebegrebet har for udviklingen af den gode praksis. Hensigten er, at deltagernes refleksioner skal udfordre den pædagogiske praksis i deltagernes egne institutioner. Fokus rettes mod diversiteten i børnegruppen og udviklingen af handlekompetencer og aktiv deltagelse for alle børn.

I undervisningen på VIDA-Basis + sættes der yderligere fokus på, hvordan forældrene inddrages i den gode praksis.

Målet med de første fem uddannelsesdage er at skabe et teoretisk og vidensbaseret fundament. Med afsæt i dette fortsætter uddannelsen de to sidste uddannelsesdage med fokus på refleksion og analyse af praksis og udvikling af mål og nye ideer.

Sjette uddannelsesdag introduceres deltagerne til arbejdet med VIDA-refleksionsværkt $\varnothing$ jet. Målet er, at deltagerne føres ind i og kommer til at forstå refleksionsværktøjet og kompetenceprofilanalyserne. Intentionen er, at deltagerne efterf $\varnothing$ lgende vil være i stand til målrettet og systematisk at kunne vurdere egne handlekompetencer og børns kompetenceudvikling samt anvende kompetenceprofilerne. Deltagerne skal endvidere kunne opstille mål for fortsat refleksion og analyse med udgangspunkt i kompetenceprofilanalyser. Der iværksættes refleksioner over betydningen af forskelle mellem pædagogers kompetenceudviklende pædagogiske indsatser og børns kompetenceudvikling. Der er fokus på begreberne og forskellen imellem "ideelle" og "reelle" handlekompetencer. Endvidere præciseres det, at der i arbejdet med værktøjet må tages højde for, at man i processer, der involverer social inklusion og eksklusion, skal forstå handlekompetencer på baggrund af den enkeltes samhørighed med fællesskabet og de kollektive identiteter, som er knyttet til de aktuelle handlekompetencer. Deltagerne arbejder med opstilling af refleksionsspørgsmål på baggrund af fiktive VIDA-refleksionsværkt $\varnothing$ jsrapporter. 
På VIDA-Basis + sættes der desuden fokus på, hvorledes pædagogiske medarbejdere kan unders $\emptyset$ ge forældrenes kompetencer og forældrenes syn på børnenes kompetencer.

Syvende uddannelsesdag sættes der processer i gang, der har til formål at bringe deltagernes opnåede viden, erfaringer, refleksioner og kompetencer i spil i eget dagtilbud. Centrale spørgsmål er: Hvilken viden er tilegnet? Hvordan kan der skabes kobling mellem praksis og teori? Hvilken viden vil du /I sætte i spil i institutionen? Hvordan vil I sikre, at den viden, I har oparbejdet og reflekteret over, ikke går tabt, men bliver sat i spil? Hvad er jeres rolle i den forbindelse? Har I en strategi? Hvilke milepæle vil I sætte for implementering af viden i egne institutioner for den kommende periode i projektet?

\subsection{VÆERKTØJER TIL REFLEKSION OG UDVEKSLING AF VIDEN OG ERFARINGER}

I det følgende beskrives, hvordan deltagerne introduceres til projektets materialer og værkt $\varnothing$ jer. Disse er beskrevet mere indgående i VIDA Statusrapport 1 (Jensen et al., 2011: 29). Der er bl.a. tale om VIDA-refleksionsværkt $\varnothing$ jet, og hvilke opmærksomhedspunkter der er centrale i arbejdet med værktøjet. Endvidere præsenteres SharePoint, som er en digital platform, der er udviklet i forbindelse med vidensdeling i projektets uddannelsesdel.

I undervisningens fase 1 præsenteres deltagerne for VIDA-refleksionsværkt $\varnothing j$ jet. Dette værkt $\varnothing j$ kan st $\varnothing$ tte deltagernes refleksioner over forholdet mellem børnegruppens udvikling og læringsmiljøet som ramme for børnenes udvikling.

VIDA-refleksionsværkt $\varnothing$ jet er udviklet af Aarhus Universitet, forskere ved Institut for Uddannelse og Pædagogik, med afsæt i den begrebsramme, som ligger til

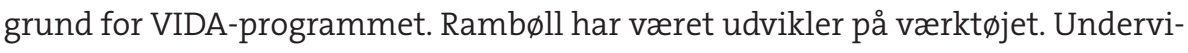
sere fra University Colleges og de kommunale pædagogiske konsulenter er blevet introduceret til brug af it-værkt $\varnothing$ jet på en temadag hos Rambøll. Underviserne

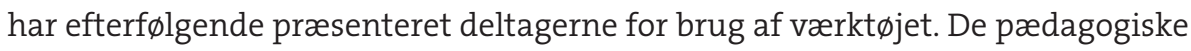
konsulenter har, som kommunale tovholdere, stået for oprettelse af strukturen i

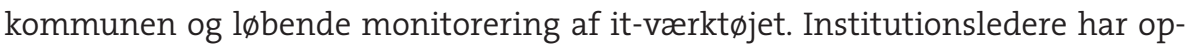
rettet medarbejdere og børn i VIDA-refleksionsværkt $\varnothing$ jsprogrammet, og medarbejdere har besvaret spørgeskemaer om egne kompetencer og børnenes kompetencer. 
Undervisningen har en induktiv karakter, hvor der veksles mellem deltagernes arbejde med refleksionsværktøjet og oplæg fra underviser. Der er fokus på tre spфrgsmål: Hvad kan værktøjet? Hvad skal pædagogiske medarbejdere være opmærksomme på, når spørgeskemaerne besvares? Hvad skal pædagogiske medarbejdere være opmærksomme på i analysen af rapporterne?

Undervisningen er organiseret således:

1) Mindre oplæg, hvor der stilles skarpt på, hvad værktøjet kan, og hvad man skal være opmærksom på i besvarelsen af spørgeskemaerne

2) Deltagere arbejder med refleksionsværkt $\varnothing$ jet i et fiktivt "rum" som fiktive medarbejdere. Underviseren har oprettet en fiktiv institution, fiktive medarbejdere og børn i VIDA-refleksionsværktøjet. Deltagerne udfylder og arbejder derefter med spørgeskemaerne ved egne computere, der er koblet til stedets netværk

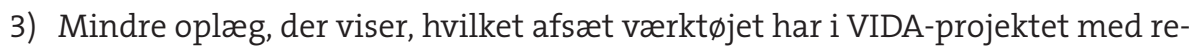
latering til inklusion, og hvad man skal være opmærksom på i analysen af rapporterne

4) Deltagere stilles en opgave på baggrund af en fiktiv rapport fra VIDA-refleksionsværkt $\varnothing$ jet:

- Læs rapporten

- Forestil jer resultaterne er fra jeres institution

- Analyser resultaterne

- Hvilke refleksionsspørgsmål giver det anledning til

- Skriv et spфrgsmål ned og fremlæg i plenum

5) Refleksionsspørgsmål behandles i plenum. Det diskuteres, hvilke forhold der er eller kan opstå mellem spørgsmålet og principperne for det samlede VIDAprojekt

6) Kort afslutning.

I undervisningen fremtræder det tydeligt, at VIDA-refleksionsværkt $\varnothing$ jet er udviklet til at kunne unders $\varnothing$ ge og efterf $\varnothing$ lgende underst $\varnothing$ tte udviklingen af handlekompetencer i børnegruppen og i personalegruppen. Formålet med refleksionsværkt $\varnothing j$ jet er således at bidrage til, at det pædagogiske personale og ledelsen unders $\varnothing$ ger, analyserer og reflekterer over egen praksis og på den baggrund igangsætter eventuelle fornyelser. Værkt $\varnothing$ jet retter således fokus på børnegruppens udvikling og på læringsmiljøet som ramme for børnenes udvikling. 
Ved udfyldelsen af både medarbejderskema og barneskema understreges det i undervisningen, at hvor kompetent man er, er indre kvaliteter, men i praksis bestemmes det også af de sociale og materielle forhold, som man indgår i, når man bruger sine kompetencer. Det betyder, at medarbejderen skal vurdere de kompetencer, hun har mulighed for at bruge i det daglige arbejde, når hun udfylder medarbejderskemaet. I udfyldelsen af barneskemaet skal de kompetencer, barnet har mulighed for at bruge i institutionen, vurderes.

I deltagernes analyser af VIDA-kompetencerapporterne er det tydeligt, at programmet bygger på en antagelse om, at udviklingen af handlekompetencer hos institutionens børn og deres professionelle voksne er tæt forbundet. Rapporten er et subjektivt udtryk for de pædagogiske medarbejderes vurdering af børnenes og pædagogernes kompetencer, og det er ud fra et voksenperspektiv, at skemaerne er besvaret. Det pointeres endvidere, at ideelle og reelle handlekompetencer ikke er det samme som det ideelle og reelle barn.

VIDA SharePoint er en digitalplatform specifikt udviklet til VIDA. Platformen er et værkt $\varnothing$ j, hvor deltagerne i VIDA kan dele viden med hinanden. Derudover fungerer den også som en digital logbog, der kan dokumentere de pædagogiske processer, således som de forl $\varnothing$ ber hos de involverede dagtilbud. Intentionen med SharePoint er således at give deltagerne i VIDA-projektet muligheder for at lade sig inspirere af hinanden og dele erfaringer og viden på tværs af institutioner. I fase 1 sker det inden for den kommunale ramme.

Ledere og medarbejdere fra deltagende dagtilbud er således ansvarlige for at dokumentere arbejdet fra dets spæde start gennem indrapporteringen i SharePoint. Hver undervisningsgang afsluttes derfor som nævnt med, at deltagerne arbejder med uddelte refleksionsspørgsmål, tager dem med sig hjem til institutionerne og arbejder videre med 'forstyrrelsen' i den samlede medarbejdergruppe i dagtilbuddet, bl.a. via SharePoint-sitet. Der er fjorten dage imellem de enkelte undervisningsgange. I den periode forventes det, at institutionerne kommunikerer og reflekterer via SharePoint-sitet. I forhold til evaluering af interventionerne er det målet, at SharePoint anvendes til at registrere, hvad og hvordan alle de deltagende dagtilbud implementerer interventionen. SharePoint har desværre ikke fungeret helt efter hensigten. SharePoint er primært blevet brugt til deling af grupperefleksioner i forlængelse af uddannelsesdagene, hvorimod der ikke har været særlig meget aktivitet i de perioder, hvor der ikke har været undervisning. Deltagerne fortæller, at de har haft en del tekniske problemer med at få adgang til sitet, hvilket har forårsaget irritation og frustrationer. 


\subsection{AFSLUTNING OG PERSPEKTIVERING}

Formålet med den f $\varnothing$ rste fase i uddannelsesforl $\varnothing$ bet er, at deltagerne opbygger en fælles base af forskningsbaseret viden om udsatte børn. Uddannelsesforl $\varnothing$ bet er tilrettelagt omkring VIDA-kvalifikationsmappens første del, hvor der præsenteres evidensbaseret viden om 1) social arv, udsatte børn, baggrund, begrebet om læring og kompetence, in- og eksklusion samt 2) viden om effektfulde interventioner baseret på international forskning samt 3) lovgivningen på feltet (Jensen, 2011: 35). Denne forskningsbaserede viden bliver i undervisningen bragt i spil med praktikernes både implicitte og eksplicitte erfaringsbaserede viden. Formålet med denne proces er dels, at der skabes ny teoretisk viden, og dels, at deltagerne på baggrund af denne viden får mulighed for at udvikle deres pædagogiske faglighed.

VIDA projektets princip om organisatorisk læring og innovation (Jensen et al., 2011a, kap. 3) inddrages i undervisningsmæssige sammenhænge ved, at lederen og den pædagogiske medarbejder, som deltager på uddannelsen, bringer den forskningsbaserede viden med hjem i deres institutioner. Som formuleret i Jensen et al, (2011a, 35) er:

"Intentionen bag hele uddannelsesforløbet er dels, at deltagerne på baggrund af undervisning, de indbyggede vidensbaserede materialer og udviklingsværktøjer, selv sætter fokus på at udvikle viden, refleksioner og redskaber til at arbejde med deres egen praksis, og dels at deltagerne opnår viden om, hvordan evidensbaseret viden og refleksioner kan udfoldes i dagtilbuddet og danne grundlag for nye pædagogiske praksisser i organisationen på måder, som involverer alle medarbejdere" (Ibid.: 35).

Der undervises derfor ikke i et færdigt interventionsprogram, som den enkelte institution skal anvende, men der lægges derimod op til et aktivt læringsperspektiv, som bl.a. indebærer, at deltagerne ud fra den forskningsbaserede viden, som de præsenteres for, deres refleksioner og herefter kommende handlinger selv udarbejder deres lokale fortolkning af de VIDA-guidelines, som alle er forpligtede på at arbejde med og omsætte konkret i eksperimenter og forandringer af praksisser. I VIDA-undervisningen møder deltagerne således løbende refleksionssp $\varnothing$ rgsmål, som bl.a. sætter spфrgsmålstegn ved deres nuværende daglige pædagogiske praksis. Ligeledes kan den forskningsbaserede viden, som VIDA-deltagerne præsenteres for, sætte nogle refleksioner i gang hos deltagerne, dette er punkt 1. Det andet punkt handler om, at deltagerne enkeltvis, i grupper, i refleksionsrummet 
og hjemme i deres institutioner ud fra de kritiske spørgsmål, der melder sig ud fra punkt 1, diskuterer, gennemtænker og sidenhen, punkt 3, kommer med forslag til nye innovative handlinger, ud fra både deres egne erfaringer og den nye viden de har fået, således at den pædagogiske praksis nyfortolkes. Det er her, hvor institutionen udvikler og afprøver nye praksishandlinger for institutionen, som der så igen skal reflekteres over (Ibid.: 105). Dette vil VIDA-undervisningens anden fase have særligt fokus på.

Uddannelse har således været i fokus i VIDA-projektets fase 1. Deltagerne har tilegnet sig viden om VIDA-Basis og VIDA-Basis +. Det er målet, at denne uddannelse og undervisning skal medvirke til, at deltagerne opnår viden og indsigt, får erfaringer, færdigheder og kompetencer samt bliver trænet i at gøre sig refleksioner, der kan underst $\varnothing$ tte institutionens innovative udviklingsarbejde med VIDA-projektet. I den igangværende fase 2 skal der formuleres mål, strategi og systematiske planer for gennemførelsen af eksperimenterne med fokus på kollektiv læring, innovation og evaluering af den lokale fornyelsesproces. Det centrale princip fra fase 1 om at sætte viden i spil forstærkes i fase 2, fordi det nu skal vise sig, om viden faktisk er sat i spil VIDA-institutionerne. Fase 2 lægger på den måde op til, at deltagerne udvikler innovative kompetencer og bliver i stand til at omsætte handlingsstrategier og systematiske planer i lokale eksperimenter og til at analysere, hvad der virker ude i praksis gennem evaluering af egne fornyelsesprocesser (se VIDA-statusrapport 1 for uddybende beskrivelser af uddannelsens forskellige faser).

VIDA-projektet har været i gang siden marts 2011, og indsigt og fortrolighed præger deltagernes udsagn her i begyndelsen af undervisningen i fase 2. Eksperimenter og organisatorisk læring kommer mere i fokus i VIDA-uddannelse og implementeringsdelen i 2012. 
VIDENSBASERET INDSATS OVER FOR UDSATTE BøRN I DAGTILBUD 


\section{LEDERKURSER I FACILITERING: HVORDAN LEDERE STIMULERER ENGAGEMENT OG INNOVATION PÅ MØDER}

Ib Ravn

\subsection{UDFORDRINGEN}

Den konkrete ledelsesudfordring, vi ser på i denne del af uddannelsesforl $\varnothing$ bet, er, hvordan man organiserer den samtale og løbende refleksion i dagtilbuddet, som skal føre til en ændret praksis i retning af mere inkluderende børnefællesskaber. "Organisatorisk læring" og "institutionel innovation" er store ord, der skal betyde noget i dagligdagsinteraktioner, når ledere og medarbejdere mødes og udveksler erfaringer. Facilitering er det ledelsesværkt $\varnothing$ j, vi bringer i anvendelse her. Når man faciliterer, styrer man samtalen og refleksionen hensigtsmæssige steder hen, på en måde så alle inddrages og har medejerskab, og der skabes konkrete resultater, effektivt.

\subsection{TRANSFER, FORANKRING OG LEDELSE AF KOMMUNIKATION $P A ̊ M \emptyset D E R$}

Input til praktikeres forandringsprocesser kan man fint give på kurser, men overføring af det lærte, dvs. transfer, til arbejdspladsen er notorisk vanskeligt (Tennant, 1999; Wahlgren, 2009). Typisk vil den, der har været på et vellykket kursus, fortælle begejstret om det til højre og venstre, og også gerne under mere formelle former på et personalemøde.

En leder vil fx bruge en halv time på at fortælle om alt det nye, i dette tilfælde: Hvor vigtigt det er, "at vi her på institutionen gør noget nyt for at skabe mere 
inklusive fællesskaber". Oplægget konkluderes måske med ordene: "Nu skal vi simpelthen i gang, mener I ikke også det?" Efter sådan en peptalk stiller medarbejderne spørgsmål, nogle er velvillige, andre er kritiske, og der diskuteres frem og tilbage, anf $\varnothing$ rt af de sædvanlige tre-fire højesttalende kolleger, og så skal man ellers videre i den pressede dagsorden. Medarbejderne føler sig måske ikke specielt godt involverede i sagen. Der kommer jo så meget nyt, man skal forholde sig til. Hvis lederen sætter nye initiativer i gang senere, er opbakningen og forankringen blandt medarbejderne måske mangelfuld, og forandringerne løber let ud i sandet (Ravn, 2011a).

Forskning i kommunikation på møder (Ravn, 2011b) viser, at envejskommunikerende oplæg fra ledere og gemene ustyrede plenumdiskussioner ikke er optimale. Det er velkendt, at oplæg skal være korte for at have nogen effekt (Bligh, 2000), og at de i bedste fald kan tjene som input til en videre bearbejdning i tilhørernes bevidsthed og praksisverden (Ravn, 2007; Høyrup m.fl., 2002). En sådan bearbejdning opnås sjældent i den frie diskussion, som deltagerne i god demokratisk forståelse opfatter som deres lejlighed til at bidrage med de veletablerede synspunkter, de nu måtte have.

En fritløbende diskussion er ikke i egentligste forstand en læringsproces, hvor nyt materiale tages ind, bearbejdes, modificeres og anvendes af hver enkelt. Den kan være det og er det også somme tider, specielt dér hvor deltagerne i forvejen er topmotiverede for det nye materiale og interesserer sig for det. Lige så ofte spredes fokus af deltagerindlæg med irrelevante associationer, pointel $\varnothing$ se anekdoter, emotionelle reaktioner og assorterede fordomme. Under alle omstændigheder er det tilfældigt, om en diskussion fører til et resultat (Ravn, 2012). Somme tider har man en god og frugtbar snak, der peger fremad, og somme tider har man ikke. Sådan er det på næsten alle møder. Lederen kan ikke styre den fælles samtale det gode sted hen; det sker bare af sig selv - når det altså sker.

Det vil sige: Lederen kan ikke lede. Hun er prisgivet deltagernes luner, som de nu udspiller sig i den diskussion, der bølger frem og tilbage. Hun kan lukke en samtale og tvinge personalet videre frem ad dagsordenen til et nyt emne, men hun har svært ved bevidst at lede samtalen i en inspirerende, lærende eller innovativ retning.

Mфdet er lederens multipersonelle ledelsesforum (Ravn, 2011a); det er stort set det eneste sted, alle medarbejderne samlet møder hende. Hvis hun ikke kan lede medarbejderne i samlet flok, er det vanskeligt at skabe betingelserne for organisatorisk læring og praksisinnovation. Lederen skal ikke alene ønske eller ville 
træde i karakter som leder, hun skal også have de praktiske redskaber til at lede kommunikationen blandt sine medarbejdere. Til den ende iværksatte vi et træningsforl $\varnothing \mathrm{b}$ i facilitering.

I VIDA-Basis +, hvor samarbejdet med forældrene inddrages, består der en vigtig ledelsesmæssig udfordring i at organisere forældresamarbejde, så også de marginale eller ressourcesvage forældre (dem med de udsatte børn) inkluderes og trækkes inden for pædagogisk rækkevidde. Forskning peger på, at der er tre vigtige steder for forældrekontakt: a) forældremødet med dagsorden og diskussioner, b) de mere sociale sammenkomster med forældrene i institutionen og c) afleverings- og afhentningssituationen morgen og eftermiddag (Kousholt, 2009). De to første kan der arbejdes med ved hjælp af facilitering, mens den sidste er en en-til-en kommunikation, der kan sammenlignes med "den vanskelige samtale" (Damgaard, 2000) og bedst tackles kommunikationsteknisk. Forældremødet er en mødekategori, der ligner personalemødet, blot typisk med mere orientering fra leder/pædagog og mindre diskussion. Formen fungerer ikke specielt inkluderende for ressourcesvage forældre.

Det sociale forældrearrangement er heller ikke nemt at være til stede i, om det så er åbent hus, arbejdsdag, fællesspisning, fernisering eller uformelt samvær efter julekrybbe, teater eller sang. Alle sidder og snakker med gamle venner og bekendte eller trasker rastløst rundt på jagt efter et kendt ansigt. Nye eller marginale forældre lukkes sjældent ind i varmen. Enhver må klare sig selv, og som ny skal man have stærke sociale kompetencer for ikke at blive hægtet af. Trods personalets bedste intentioner marginaliseres der til den store guldmedalje - som de problematiske forældres notorisk beskedne fremmøde også bevidner. Også samværet uden for mødet skal der således tages langt bedre hånd om fra ledelsens side.

\subsection{FACILITERING SOM LEDELSESVÆERKTØJ}

Facilitering er den kunst at styre en forsamlet gruppe menneskers kommunikation, på en sådan måde at alle inkluderes, og gruppen skaber de resultater, den $\emptyset$ nsker. Facilitator styrer primært på mødets form og processer (Hunter, 2007), hvor en traditionel mødeleder mere styrer på indhold. Enhver leder bør kunne facilitere sine medarbejdere på møder, samtidig med at hun giver dem retning på samtalens indhold og bidrager substantielt til de beslutninger, somme tider afgørende, som ledelsesansvaret kræver (Bens, 2006). 
Hvor en mødeleder opfatter det som sit ansvar at sammensætte og afvikle en dagsorden, herunder styre talerrækkefølgen samt konkludere på diskussionerne og føre et evt. resultat til referat, er facilitators opgave mere dynamisk og moderne. Mødeledelse som disciplin har stået stille i 30-40 år, hvorimod ledelse har ændret sig med raketfart. At facilitere er at lede et møde på en måde, så der gives plads til nyere aspekter af ledelsesgerningen som bl.a. engagement, mening i arbejdslivet, anerkendelse, visionsrettethed, social innovation og værdiskabelse.

Fra forsknings- og udviklingsprojekter ved vi, at man kan udvikle lederes færdigheder i facilitering, så de skaber bedre møder for sig selv og deres medarbejdere. Specielt vidensprocesser, såsom ledelsesinformering og den klassiske bordrunde, kan udvikles og nuanceres, så det bliver lettere at forankre budskaber, dele viden, generere ideer og forberede handling (Ravn og Rokkjær, 2006; Ravn 2011a og c; 2012; Christensen, 2007).

Dagtilbud er arbejdspladser som alle andre, og ledelse dér byder på både lignende og anderledes udfordringer. Offentlig ledelse har udviklet sig særlig markant de sidste par årtier, og specielt i daginstitutioner er 1970'ernes udbredte forestilling om "kollektiv ledelse" et udgangspunkt for mange praktiske reformer af ledelsesarbejde og -ansvar (Socialstyrelsen, 1979). Særligt hvad angår møder og erfaringsudveksling er lederens rolle vanskelig, fordi kulturen på det sociale område og pædagogiske arbejdspladser i nyere tid er udpræget "demokratisk" eller rettere egalitær: "Vi har alle sammen ret til at sige hvad vi mener, og den ret tager vi” (Ravn, 2011a; 2012). Sådan nogle møder tager tid og skaber færre resultater, end godt er.

Træning i facilitering i en demokratisk arbejdskultur må dreje sig om to ting: dels at give den udbredte opfattelse af alles taleret et udtryk, der ikke tager evigheder, og dels at give lederen værkt $\varnothing$ jer til at skære igennem med og rette samtalen frem mod et mål. Med andre ord: Der skal inkluderes på anden vis end gennem plenumdebatter, og mødet skal rettes skarpere mod at skabe resultater - i dette tilfælde: vilje til social innovation og realistiske planer for den.

\subsection{TR/ENING I FACILITERING: PAEDAGOGISKE PRINCIPPER OG TILRETTEL/EGGELSE}

Facilitering læres mest effektivt på workshops, hvor deltagerne samles til hele dages koncentreret træning. Vi gennemf $\varnothing$ rte et tredages træningsforl $\varnothing b$ for le- 
derne i de fire VIDA-kommuner. Kun lederne deltog i modsætning til i uddannelsesforløbet, hvor også en medarbejder fra hvert dagtilbud var med af hensyn til forankringen hjemme på arbejdspladsen. Rationalet for kun at medtage lederne i faciliteringsforløbet var at signalere ledelsesansvar og -kompetence: Lederne skal træde i karakter og vise, at de kan lede deres folk, når de alle er forsamlet hvilket som nævnt oftest sker på møder.

Principielt kan facilitatorrollen godt varetages af andre end lederen (Ravn, 2011a; Hogan, 2003), men i denne sammenhæng skønnede vi det essentielt, at lederen viste flaget og udviklede sin evne til at styre vidt - og bredt - og højttalende medarbejdere - og sit mod til at gøre det.

I overensstemmelse med VIDA-projektets unders $\varnothing$ gelsesdesign holdt vi lederne fra VIDA-dagtilbud adskilt fra lederne i VIDA-Basis +-dagtilbud (idet VIDA-Basis + jo består af institutioner, der også skal arbejde bevidst med forældresamarbejdet i fors $\varnothing$ get på at skabe mere inkluderende børnefællesskaber). Hver gruppe på ca. 40 ledere fik altså sit forløb på tre workshops. De to første lå et halvt år efter uddannelsesforløbet (fase 1), og den tredje, til opsamling, lå en måned efter igen. Indholdet $\mathrm{i}$ de to tredages forl $\varnothing \mathrm{b}$ var ens, bortset fra at andendagen for VIDA-Basis +-lederne for to tredjedeles vedkommende handlede om facilitering af involvering på forældrem $\varnothing$ der og -arrangementer.

Facilitering er en praktisk færdighed, og i den skal færdigheder $\varnothing$ ves for at blive lært; forelæsninger er ikke nok (Bransford m.fl., 2000). Da facilitering er noget, man gør med grupper, sammensættes deltagerne på workshoppen i skiftende grupper på 4-8 personer, hvis arbejde faciliteres af en af deltagerne. Hver gruppes facilitator instrueres inden gruppem $\varnothing$ det, således at mødet kan afvikles på den inkluderende og målrettede måde, der netop er essensen af facilitering: involvering og resultatskabelse.

Som så mange andre workshops var formen på disse en blanding af korte oplæg, $\varnothing$ velser og en efterf $\varnothing$ lgende debriefing af $\varnothing$ velserne i plenum, hvor der reflekteres over $\varnothing$ velsen, og læringspointer identificeres. Et sådant sæt af oplæg, фvelser og debriefing kalder vi et modul, og det varer typisk 60-90 minutter. Dem er der 1-2 af f $\varnothing$ r frokost og 2-3 efter samt evt. 1-2 om aftenen. 
Program for workshopdage i VIDA

\begin{tabular}{|c|c|c|}
\hline Dag & Modul & Emne \\
\hline \multirow[t]{8}{*}{1} & \multicolumn{2}{|r|}{ Mødefacilitering. Brug af styrker og ressourcer } \\
\hline & M1 & $\begin{array}{l}\text { Oplæg om facilitering, med faciliteret proces til drøftelse } \\
\text { heraf. }\end{array}$ \\
\hline & M2 & $\begin{array}{l}\text { Faciliteret smågruppem } \varnothing \text { de. Om deltagernes udfordringer } \\
\text { på møder. }\end{array}$ \\
\hline & M3 & Mødeteknikker: Mødediamanten og drejebog. \\
\hline & M4 & $\begin{array}{l}\text { Bedste erfaringer med m } \phi \text { der. Hvordan man bruger dem på } \\
\text { egne møder. }\end{array}$ \\
\hline & M5 & $\begin{array}{l}\text { Styrkebrug: Hvad giver dig energi i hverdagen vedrørende } \\
\text { VIDA-emner? }\end{array}$ \\
\hline & M6 & Netværksproces på gulv. Deltagerne møder fremmede. \\
\hline & M7 & $\begin{array}{l}\text { Vidensbørs. Vidensdeling til uddybning af kompetencer og } \\
\text { udfordringer på tværs i forsamlingen. }\end{array}$ \\
\hline \multirow[t]{5}{*}{2} & \multicolumn{2}{|r|}{ At træde i karakter som facilitator } \\
\hline & M1 & $\begin{array}{l}\text { Det fokuserede møde: Teknikker til præcis mødestart. Tek- } \\
\text { nikker til fokusering af den vildfarne diskussion. }\end{array}$ \\
\hline & M2 & $\begin{array}{l}\text { Ledelse af læring, trivsel og inklusion. Oplæg med facilite- } \\
\text { rede drøftelser i personalem } \varnothing \text { delignende grupper. }\end{array}$ \\
\hline & M3 & $\begin{array}{l}\text { Implementering af nye m } \varnothing \text { deformer. Fastholdelse af organi- } \\
\text { satorisk innovation. }\end{array}$ \\
\hline & M4 & Takeaways: Dagens læringer for hver deltager personligt. \\
\hline \multirow[t]{3}{*}{3} & \multicolumn{2}{|r|}{$\begin{array}{c}\text { VIDA-Basis +: Forældresamarbejdet } \\
\text { (disse moduler erstattede de ovenfor anf } \varnothing \text { rte } M 2 \text { og M3) }\end{array}$} \\
\hline & M2 & Facilitering af forældrem $\varnothing$ der. \\
\hline & M3 & $\begin{array}{l}\text { Forældrekontakten i aflevere-hente-situationen: Faciliteret } \\
\text { proces til erfaringsudveksling og idegenerering. }\end{array}$ \\
\hline \multirow[t]{5}{*}{4} & & Opsamling og videref $\varnothing$ relse \\
\hline & M1 & $\begin{array}{l}\text { Teori og historie: Facilitering som ledelsesværkt } \varnothing \text { j hinsides } \\
\text { kollektiv ledelse og New Public Management. }\end{array}$ \\
\hline & M2 & ‘Good practice’ med facilitering og ressourcetilgang. \\
\hline & M3 & Lederen som rollemodel i hverdagen og på møder. \\
\hline & M4 & Dagens læringer. \\
\hline
\end{tabular}


Som det fremgår, blev facilitering som styringsværkt $\varnothing j$ sat ind i en sammenhæng af ledelse og udnyttelse af ressourcer og deltagernes erfaringer, specielt forstået som ressourcer og udfordringer. Disse temaer blev behandlet, udvekslet og tacklet i faciliterede smågrupper, parvise summegrupper og cirkulerende processer i plenum.

\subsection{PERSPEKTIVERING}

Med træningen af ledere i facilitering sætter VIDA fokus på et blindt punkt i mange fors $\varnothing \mathrm{g}$ på lederudvikling og organisatorisk organisation: Når leder og personale sidder til et mфde og skal finde ud af at lave noget nyt og bedre sammen, kan de så finde ud af det? Hvad skal forhindre, at det hele ikke bliver ved snakken, men bliver ordentligt forankret og realiseret i hverdagen? En væsentlig forudsætning er, at den transfer af viden og refleksionstilbøjelighed, som lederne tager med sig fra VIDAs uddannelsesforl $\varnothing b$, bliver kommunikeret til resten af personalet, så der skabes interesse og vilje til organisatorisk innovation. Tager leder facilitatorrollen på sig, skulle vi forbedre chancerne for, at samtale og dernæst udvikling kommer i gang.

Facilitatorrollen synes velegnet til arbejdspladser, der traditionelt har været kollektivt anlagte, og hvor en leder ikke sættes på en piedestal af sine medarbejdere. Udfordringen for lederen består her i at spille sin lederrolle på en ny måde, der ikke er en tilbagevenden til den autoritære model, men som indebærer en systematisk inddragelse af medarbejdernes perspektiver og stemmer, således at den institutionelle udviklingsindsats bliver en fælles sag.

Hvor en leder f $\varnothing$ rhen blot kunne give ordet til samtlige medarbejdere i rundkredsen, og mødet derfor tog fem timer, har den moderne leder mindre tid til at udvirke den samme deltagelse, og her træder facilitators distribuerede processer til mødedeltagelse og involvering ind: summe med sidemand, gensidige anerkendende interview, lyt og byt, tavs refleksion, styrkeopdagelse i makkerpar, lynrunden, anerkendelse i trioer, personlige takeaways osv.

Når der så vedtages ændringer i dagtilbuddets pædagogiske praksisser, der tilsigter en højere kvalitet i det pædagogiske arbejde, skal disse ændringers skæbne, herunder deres implementering, justeringer og fastholdelse løbende monitoreres af ledere og medarbejdere i fællesskab. Dette kræver også mødeformer af mere dynamisk og proaktiv karakter end den sædvanlige bordrunde, hvor vi fortæller, hvad vi lavede i sidste uge, og hvilke problemer det gav. 
Den løbende næring af organisatorisk innovation gennem anerkendende og problemopløsende vidensdelingsm $\varnothing$ der undervejs i processen bliver fokus for næste ombæring i undervisningen i facilitering, sent i 2012. 


\section{LEDERES BESKRIVELSE AF FORANDRINGSPROCESSER I DET SAMLEDE DAGTILBUD}

\section{- I ET PERSPEKTIV OM ORGANISATORISK LAERING}

Ulrik Brandi \& Bente Jensen

\subsection{INDLEDNING}

På baggrund af kvalitative data fra baseline interview med samtlige ledere i VIDA-Basis og VIDA-Bais +-dagtilbud bliver potentialerne for at implementere VIDA-programmerne i et organisatorisk læringsperspektiv belyst. For at besvare dette overordnede spørgsmål er surveyunders $\varnothing$ gelsen, som blev præsenteret i VIDA-statusrapport 2 (Jensen et al., 2011), suppleret med en dybtgående kvalitativ interviewunders $\varnothing$ gelse med samtlige deltagende ledere og assisterende ledere (i særligt store dagtilbud). Analysen af de kvalitative interview er bygget op omkring tre forskningsspørgsmål:

Hvordan arbejder ledere med at skabe grundlag for vidensdeling og organisatoriske læreprocesser i dagtilbuddet set som basis for, at VIDA-programmet bliver til læring og forandring i det samlede dagtilbud?

Hvordan er den eksisterende praksis i VIDA-dagtilbud i udgangspunktet med hensyn til læring, trivsel og social inklusion, generelt og specifikt, rettet mod socialt udsatte børn? 
Hvilke fremmende og hæmmende faktorer fremhæver lederne som udfordringer i arbejdet med udsatte børn? - og videre i forlængelse heraf: Hvad er ledernes opfattelse af og forventninger til, at VIDA kan gøre en forskel?

Analyser af disse spørgsmål anses som værdifulde, idet de vil give supplerende informationer til analyser af effekter af indsatsen afslutningsvis.

Lederne bliver derfor stillet spørgsmål som: Hvilken betydning har faglig viden for dit dagtilbuds arbejde med udsatte børn, og hvad gør du, når du skal inddrage ny viden i dit dagtilbud? Hvordan st $\varnothing$ tter du dine pædagogiske medarbejdere i at udvikle kvalitet i arbejdet med udsatte børn? Hvad sætter I i jeres dagtilbud fokus på i forbindelse med arbejdet med udsatte børn? Hvilke konkrete aktiviteter har I gode erfaringer med med hensyn til at arbejde med de tre områder læring, trivsel og inklusion? Hvilke udfordringer står I med i relation til arbejdet med udsatte børn? Endelig er der også spurgt: Hvilke forventninger har du til, at VIDAprojektet vil gøre en forskel for udsatte børn nu og på længere sigt? På den måde bliver det muligt at analysere sammenhænge mellem strategier for arbejdet med børns, herunder udsatte børns, læring, trivsel og inklusion og påvirkningskilder og en forholden sig til disse, som lederne beretter det.

Datagrundlaget består af båndede og transskriberede interview med alle deltagende ledere fra hhv. VIDA-Basis- og VIDA-Basis +-dagtilbud ( $\mathrm{N}=75)$, som er interviewet sommeren 2011 i forlængelse af baseline-unders $\varnothing$ gelsen (se Jensen et al., 2011b). Analysen er gennemført dels ved hjælp af analyseprogrammet Atlas. ti og dels ved deskriptive analyser af fænomeners forekomst, deres udbredelse og sammenhæng i materialet samt tolkninger baseret på et teoretisk og empirisk udgangspunkt.

Den indledende analyse af baseline-data fra VIDA-surveyundersøgelsen (jf. VIDA-statusrapport 2, kap. 2) viste, at deltagerne har forskellige forudsætninger i forhold til at arbejde med organisatorisk læring rettet mod implementering af VIDA-programmet. Den teoretiske og empiriske baggrund (se VIDA-statusrapport 1, Jensen et al., 2011a) giver anledning til at kredse om forholdet mellem såkaldte eksplicitte beskrivelser af praksis og ledelse af vidensprocesser og praksisudvikling, den rationelle handling og de mere implicitte ikke-rationelle praksishandlinger og begrundelser for disse. Analysen sætter endvidere fokus på spændingsfeltet mellem lederens strategier for innovative forandringsstrategier i dagtilbuddet og de objektive betingelser, vilkår, krav samt det at være forpligtet på at arbejde med VIDA, der gør det muligt eller vanskeligt at handle forandrende og vidensdelende i det samlede dagtilbud. En overordnet hypotese 
i VIDA-forskningsprojektet er, at den måde, VIDA forstås og kommunikeres på af lederen, er en vigtig indikator for, hvordan interventionen folder sig ud i hele organisationen. Det er påvist i et tidligere, tilsvarende interventionsstudie (HPA, Jensen et al., 2009; 2011), at lederens rolle, som den der håndterer og navigerer i relation til projektet ved at inddrage medarbejdere i forhold til at 'gøre projektet til deres eget', reflekterer bevidst over evt. vigtige magtrelationer og over indhold og organisering af nye praksisformer, har stor betydning for implementering af interventionen. Selvom nogle ledere i udgangspunktet kan udtrykke en vis afmægtighed over for nye krav og store udefrakommende udfordringer, antages det, som VIDA-uddannelsen bidrager med, at et særligt fokus på at arbejde vidensbaseret og reflekterende over praksis og udvikling er vejen frem til en effektiv implementeringsproces.

Disse forudsætninger er tidligere indkredset ud fra følgende faktorer, som antages at have afgфrende betydning for VIDA-programmets implementering: 1) institutionernes tradition for at arbejde vidensbaseret og på et teoretisk grundlag, 2) institutionernes og især ledernes arbejde med at initiere vidensdeling og skabe en åben læringskultur, der fremmer medarbejdernes læringskapaciteter, og 3) faktorer, der henholdsvis fremmer og hæmmer læring i dagtilbuddet, herunder deltagernes motivation for at deltage i VIDA.

Dette kapitel er struktureret på baggrund af ovenstående forhold. Første sektion tager afsæt i forskningsspørgsmål 1 og analyserer ledernes beskrivelser af deres arbejde med viden og læring i det samlede dagtilbud. I denne sektion belyses dagtilbuddenes forskellige organiseringsformer og strategier i forhold til at skabe grundlag for udvikling og læring i dagtilbuddet, som antages at blive påvirket gennem VIDA-interventionen og i sidste ende vil påvirke interventionens implementering og dens effekter. Anden sektion tager afsæt i forskningsspørgsmål 2 og 3 og har fokus på at unders $\varnothing$ ge, hvad der kendetegner eksisterende praksisser i deltagende VIDA-dagtilbud, både VIDA-Basis- og VIDA-Basis +-institutioner, samt en analyse af faktorer og udfordringer, der påvirker institutionsledernes opfattelse af eget og personalets udgangspunkt for at arbejde med VIDA. I forbindelse med analysen af faktorer, der kan påvirke i positiv eller negativ retning, inddrages også deltagernes forventninger til VIDA.

I den tredje sektion opsamles kapitlets resultater i forhold til de tre forskningsspørgsmål, og analysen samles i en konklusion, der fokuserer på en antagelse om forskelle. Forskelle, som umiddelbart ser tilfældige og indlysende ud og angiver et tilsyneladende individuelt perspektiv, men som set i relation til ledernes for- 
skellige baggrund, tilknytning til forskellige kommuner, erfaringer med at arbejde med forskellige læringsformer i det daglige og egne og personalets forskellige faglige og personlige baggrundsmæssige ressourcer tegner et forel $\varnothing$ bigt m $\varnothing$ nster, der peger frem mod dyberegående analyser af pædagogiske praksisformer i en sociokulturel læringskontekst.

Der vil i analysen forekomme interviewcitater med henvisninger til personer, der af hensyn til anonymitet er forsynet med en kode. En beskrivelse af undersøgelsens metode og datagrundlag findes i VIDA-statusrapport 2. Den kvalitative dataanalyse bliver opbevaret sammen med båndudskrifter fra interviewene på sikret datadrev, der er oprettet til formålet efter forskrifter angivet ved anmeldelse til Datatilsynet. Tilhørende tabeller og bokse findes i rapportens bilag, der fungerer som dokumentation for fremstillingen af kategorier og tematikker.

\subsection{LEDERENS ARBEJDE MED VIDEN OG L/ERING}

I statusrapport 2 blev det fastslået, at et af de centrale punkter, i forhold til om VIDA-programmet ville kunne udvikle læring i dagtilbuddet, var, om lederne var i stand til at udvikle redskaber og teknikker til at sikre inddragelse af medarbejdere, skabe og organisere en fælles og åben læringskultur og st $\varnothing$ tte medarbejderne i at arbejde målrettet og systematisk med opgaven, som ligger i VIDA-Basis og VIDA-Basis + (Jensen et al., 2011b, kap 2). I udgangspunktet viste analysen, at det for hovedparten af dagtilbuddene ikke er rutine at arbejde målrettet og systematisk med teori omsat i praksis hverken generelt eller over for udsatte børn. Det blev således konkluderet, at der er en række potentialer, men også barrierer til stede for processen, for at VIDA-viden hos den enkelte deltager på uddannelsen bliver kollektivt gældende i organisationen og omsat i handlinger. Sammenfattende giver analysen anledning til at overveje, hvordan VIDA videre frem kan skabe effektive, forpligtende organisatoriske læreprocesser med udgangspunkt i de afdækkede deltagerforudsætninger.

Videregående analyser sætter i den forbindelse fokus på, hvordan uddannelsen omsættes og specifikt på ledelsens rolle i arbejdet med at få VIDA-læring integreret i den samlede organisation på måder, så organisationens medlemmer (alle medarbejdere i dagtilbuddet) fastholder eller videreudvikler motivationen og oplever tillid til, at de kan få viden til at gælde på et organisatorisk niveau. Forskningsspørgsmålet 'Hvordan arbejder ledere med at skabe grundlag for vidensdeling og organisatoriske læreprocesser i dagtilbuddet set som basis for, at 
VIDA-programmet bliver til læring og forandring i det samlede dagtilbud?' er operationaliseret i tre spørgsmål:

1) Hvad betyder faglig viden for det pædagogiske arbejde?

2) Hvad gør lederne helt konkret, når de skal inddrage ny viden i deres dagtilbud?

3) Hvordan st $\varnothing$ tter lederen sine pædagogiske medarbejdere i at udvikle kvalitet i det pædagogiske arbejde?

\section{BETYDNINGER AF FAGLIG VIDEN}

Generelt set viser analysen af de indsamlede lederinterview på tværs af kommuner, at betydningen af faglig viden er stor. For hovedparten af deltagerne tilskrives faglig viden en altafgфrende rolle for at kunne fungere på kompetent vis som pædagog og som pædagogisk leder over for udsatte børn. En af lederne siger om betydningen af faglighed, at:

"Faglig viden har stor betydning. Derfor ville vi selvfølgelig helst ansætte pædagoger, som har noget viden, men det har stor betydning på den måde, men man snakker meget i dag om uddannelse, uddannelse, uddannelse..."(Y-8-153¹).

Denne type udsagn er typiske for datamaterialet, idet informanterne som udgangspunkt understreger vigtigheden af fagligt baseret viden. Når informanterne nævner ordet 'faglig viden', så refererer de til pædagogprofessionel faglig viden om fx børns udvikling, læring, adfærdsmønstre, aktiviteter, trivsel, som man kan tilegne sig fra fagligt relevante tidsskrifter og bøger. Det interessante ved udsagnet er den måde, informanten tilskriver betydning til den faglige viden på ved at koble den til uddannelse. På tværs af kommuner viser analysen, at den faglige viden er noget, der ligger indlejret i selve professionen og i det at være en uddannet pædagog. Faglighed bliver identificeret med den viden, man tilegner sig som pædagog undervejs i studiet og efterfølgende ved at holde sig orienteret i den for faget relevante faglitteratur. På denne måde bliver en vigtig betydningstilskrivning til faglig viden en kobling til professionsbaggrunden.

At faglig viden er af stor vigtighed og således ofte kobles til uddannelsesbaggrund, starter i flere interview automatisk en diskussion om relationen mellem uddannet personale og ikke-uddannet personale, som er med til at nuancere

1 Koden "Y-8-153" refererer til kommune (Y), institutionskode og sektionstal (153) i Atlas.ti analysefilen. Denne referencepraksis vil vi følge for alle citeringer i dette dokument. Bemærk at længden af institutionskoderne varierer. 
forståelsen af faglig viden. Mønsteret i datamaterialet på tværs af kommuner er, at det ikke-uddannede personale fremstår som en fagligt set svag medarbejdergruppe i de enkelte dagtilbud set i forhold til det uddannede personale. I datamaterialet kommer dette til udtryk, fx ved at informanterne ofte foretrækker at ansætte uddannede pædagoger, at fyre ikke-uddannede f $\varnothing \mathrm{r}$ uddannede, og at den uddannede pædagog er bedre til at argumentere og legitimere sig over for forældre.

Grundlæggende set handler svarene omkring betydningen af faglig viden om, hvad man i de konkrete adspurgte dagtilbud mener, udg $\varnothing$ r basis for den pædagogiske praksis. Relationen mellem uddannet og ikke-uddannet personale åbner for en diskussion mellem faglig viden og erfaringsbaseret viden, hvor den erfaringsbaserede viden indtager en mindre vigtig position som vidensform for hovedparten af de adspurgte ledere set i forhold til faglig viden. Når vi skriver 'erfaringsbaseret viden', så refererer vi til den viden, der akkumuleres fra at løse konkrete opgaver i et givent dagtilbud, fx ved at deltage i dagligdagens gøremål og være en del af arbejdspladsen. Det skal dog understreges, at dataanalysen viser en mindre variation mellem kommuner mellem faglig viden og erfaringsbaseret viden. Det skal understreges, at forholdet mellem den faglige og den erfaringsbaserede viden her fremstilles, som det opleves af de deltagende ledere i de kvalitative interview ud fra det stillede spørgsmål, og det betyder ikke nødvendigvis, at den erfaringsbaserede viden nedprioriteres eller ikke har betydning helt konkret i det specifikke dagtilbud. I datamaterialet er det kun få institutioner, som viser en tendens til, at erfaringsbaseret viden har større betydning end den faglige viden:

"Vi gør sådan, fordi... det virker! Det har vi kropslig erfaring med at det virker, og det er en praksis, der bliver vedligeholdt fra år til år, som et "plejer" og som bestemt nogle gange er reflekteret og fornuftigt, men som også nogle gange ikke er det, og som bestemt ikke altid er reflekteret for alle" (Z-4101417-178).

I udsagnet bliver den erfaringsbaserede viden koblet til et 'plejer', dvs. de vaner og rutiner, som man i dagtilbuddet har udviklet over tid. Informanten giver her udtryk for dobbeltheden i eksisterende vaner. På den ene side er der nogle vaner og rutiner, som fungerer i den konkrete praksis. På den anden side udtrykkes det også, at nogle vaner og rutiner ikke altid er "fornuftige" og kunne forbedres ved at lære nye vaner eller tilpasse de eksisterende. Spørgsmålet er i denne sammenhæng, hvordan man skal ændre de indlejrede rutiner og vaner. Beskrivelsen af eksisterende vaner og rutiner åbner således op for en læringstematik, som vi vil berøre i den følgende sektion om, hvad lederen gør, når ny viden skal inddrages 
i det respektive dagtilbud. Dette er netop ekspliciteringen af, hvordan man i de konkrete dagtilbud arbejder med at ændre praksisser.

\section{LEDERENS INDDRAGELSE AF NY VIDEN}

I det andet spørgsmål til lederne i VIDA-Basis- og VIDA-Basis +-dagtilbud om viden og læring blev der sat fokus på, hvordan lederne helt konkret arbejder med at inddrage ny viden i deres respektive dagtilbud. I analysen af datamaterialet har vi i denne sektion sat fokus på at få kortlagt de forskellige læringsformer og læringsmetoder, som informanterne fremstiller som de dominerende og derfor må antages at udgøre de mulige læringsbetingelser i de unders $\varnothing$ gte dagtilbud.

Læringsmetoder bestemmer vi til at være de konkrete måder, som lederne arbejder med at inddrage ny viden på. Generelt ser vi på baggrund af dataanalysen tre typer af læringsformer. Disse er formel læring, informel læring og læringskonteksten. Formel læring dækker i analysen over læringsmetoder, som foregår i en formaliseret ramme som fx et møde med en dagsorden, et uddannelsesforl $\varnothing b$ med et curriculum og læsning af faglitteratur. Informel læring refererer i analysen til læringsmetoder, hvor læring ifølge informanterne opstår på baggrund af sociale interaktioner i en given praksis og fællesskab. Informel læring kan fx være et møde i en netværksgruppe eller den læring, der opstår, fra at personalet løser en opgave sammen og i fællesskab reflekterer over løsningen af opgaven. Endelig har vi en tredje læringsform, som er det, vi kalder for 'læringskonteksten'. På trods af at det kunne ligne den mere formaliserede læringsform, så mener vi, at der er forskelle, som underbygger, at vi har den som selvstændig kategori.

Den primære forskel er, at de formaliserede læringsformer og tilhørende metoder er aktiviteter, som foregår på baggrund af et materiale, en case, input, oplæg etc., som antages direkte at kunne skabe grundlag for at dele viden og skabe læring baseret på dialog mellem medarbejdere, hvorimod læringskonteksten ikke direkte er rettet mod at formidle viden, men primært handler om de rammer og strukturer, der er til stede i forhold til at styre læringen i en given retning. I tabel 1 har vi beskrevet de forskellige læringsformer og læringsmetoder og sammenhænge imellem dem, som det kommer til udtryk i dataanalysen. 
Tabel 1. Læringsformer og -metoder i VIDA-Basis- og VIDA-Basis +-dagtilbud

\begin{tabular}{|c|c|c|}
\hline Læringsform & Læringsmetode & Beskrivelse \\
\hline \multirow[t]{3}{*}{ Formel læring } & Mødet & $\begin{array}{l}\text { Denne læringsmetode sætter m } \varnothing \text { - } \\
\text { det i centrum i forbindelse med en } \\
\text { aktivitet (oplæg til møde, diskussi- } \\
\text { on til møde etc.). Mødet er bestemt } \\
\text { ved at være en samling af ansatte, } \\
\text { som sammen formidler viden og } \\
\text { diskuterer oplæg, tekster, cases osv. }\end{array}$ \\
\hline & $\begin{array}{l}\text { Kursus, uddan- } \\
\text { nelse og oplæg }\end{array}$ & $\begin{array}{l}\text { Denne læringsmetode er både } \\
\text { en eksternt og internt orienteret } \\
\text { læringsmetode, idet det dækker } \\
\text { over deltagelse i en uddannelses- } \\
\text { aktivitet uden for det respektive } \\
\text { dagtilbud, hvor den enkelte eller } \\
\text { små grupper tilegner sig viden, } \\
\text { som skal overføres til det enkelte } \\
\text { dagtilbud i form af nye handle- } \\
\text { muligheder eller ved eksterne } \\
\text { konsulenter og lign. som holder } \\
\text { oplæg eller kører træningsforl } \varnothing b \text { i } \\
\text { dagtilbuddet. }\end{array}$ \\
\hline & Læse faglitteratur & $\begin{array}{l}\text { Denne læringsmetode handler helt } \\
\text { grundlæggende om, at en ansat/ } \\
\text { flere ansatte læser relevant faglit- } \\
\text { teratur som afsæt for at tilegne } \\
\text { sig ny viden som grundlag for nye } \\
\text { pædagogiske handlemuligheder. }\end{array}$ \\
\hline
\end{tabular}




\begin{tabular}{|c|c|c|}
\hline \multirow[t]{2}{*}{ Informel læring } & Netværk & $\begin{array}{l}\text { Netværk skal primært forstås som } \\
\text { interaktioner med andre faglighe- } \\
\text { der i kommunen eller møder mel- } \\
\text { lem ledere i kommunen, hvor for- } \\
\text { målet er at dele viden og erfaringer } \\
\text { i forhold til givne emner, men som } \\
\text { ikke indeholder en fast form. }\end{array}$ \\
\hline & $\begin{array}{l}\text { Medarbejderinter- } \\
\text { aktion }\end{array}$ & $\begin{array}{l}\text { Denne læringsmetode skal forstås } \\
\text { som den viden, der opbygges på } \\
\text { baggrund af interne interaktioner } \\
\text { mellem medarbejdere, og som er } \\
\text { med til at underst } \varnothing \text { tte deling og } \\
\text { skabelse af ny viden i dagtilbuddet. } \\
\text { Interaktionsformer er fx, at perso- } \\
\text { nale underviser hinanden, bruger } \\
\text { praksisfortællinger og refleksion på } \\
\text { stuen, small talk med debat etc. }\end{array}$ \\
\hline \multirow[t]{3}{*}{ Læringskontekst } & Organisering & $\begin{array}{l}\text { Denne læringsform er tæt relateret } \\
\text { til 'ledelsesstyring' og er bestemt } \\
\text { ved lederens strukturering af orga- } \\
\text { nisationens (dagtilbuddets) planer } \\
\text { og målsætninger. Således er denne } \\
\text { læringsform rettet mod organisa- } \\
\text { tionen, mens 'ledelsesstyring' di- } \\
\text { rekte er rettet mod medarbejderne. }\end{array}$ \\
\hline & Ledelsesstyring & $\begin{array}{l}\text { Denne læringsmetode handler om } \\
\text { lederrollen, og hvordan lederen } \\
\text { strukturerer og bearbejder viden } \\
\text { for medarbejdere i deres respektive } \\
\text { dagtilbud. Det kunne være en mo- } \\
\text { tiveret leder, at lederen lokaliserer } \\
\text { relevant faglitteratur, stuegang } \\
\text { med dialog med medarbejdere etc. }\end{array}$ \\
\hline & Teknologi & $\begin{array}{l}\text { Denne læringsmetode handler om } \\
\text { teknologier, som man bruger i for- } \\
\text { bindelse med at tilegne sig viden } \\
\text { (fx internettet). }\end{array}$ \\
\hline
\end{tabular}




\section{Formel læring}

Den første kategori af læringsformer er den formelle læringsform. Den formelle læringsform dækker over tre overordnede typer af læringsmetoder, som er m $\phi$ det, kursus og oplæg samt læsning af faglitteratur. Mødet kan være af forskellig type fx personalem $\varnothing d e$, stuem $\phi$ de, teamm $\varnothing$ de, aftenm $\varnothing$ de, pædagogfaglige $m \varnothing$ der etc. I det følgende præsenterer vi de forskellige forekomster eller koder, som det kaldes i det anvendte analyseprogram, af formelle læringsformer i forhold til mødet: personaleweekend med temaer, personaledag med præsentation af ny teori, personalem $\varnothing$ de, præsentation og diskussion, stuem $\varnothing$ de, diskussion af inklusion på personalemøde, pædagogisk dag med tema, refleksionsm $\varnothing$ de som vidensdeling, aftenm $\varnothing$ de med temadiskussion, gruppem $\varnothing$ de med formidling fra kursus, personalem $\varnothing$ de med debat om tema, personalem $\varnothing$ de med diskussion om en case, praktisk personalem $\varnothing$ de, pædagogfagligt møde uden medhjælper, tilpassede mødeaktiviteter efter type af viden, kursusrapportering ved personalemøde, oplæg fra ansatte om relevant emne og vidensdeling ved personalem $\varnothing$ de ved at læse og have fælles refleksioner. Vi har i dataanalysen samlet fundet 30 koder og 83 citater, som omtaler mødet som en læringsmetode, man bruger i forhold til at inddrage ny viden i dagtilbud. Det er klart den hyppigst nævnte læringsmetode i datamaterialet (se boks 1 i bilag 1).

Det er personalem $\varnothing$ det, som er den primære mødeform i de unders $\emptyset$ gte dagtilbud. Personalem $\varnothing$ det bliver dog afholdt på forskellig måde i de unders $\emptyset$ gte kommuner, idet det hos nogle er en blanding af både faglig diskussion og praktiske gфremål, mens nogle dagtilbud har udviklet personalemødet til enten at være et rent fagligt møde med oplæg og fællesdiskussion, og hos andre igen er det kortet ned og bliver afholdt som et praktisk møde, hvor den faglige diskussion foregår på fx stuem $\varnothing$ det eller et aftenmøde. På denne måde bliver det tydeligt, at personalem $\varnothing$ det er et centralt sted i dagtilbuddene, hvor ledere og medarbejdere kan udveksle viden. I det følgende præsenteres et eksempel på, hvordan man bruger personalem $\varnothing$ det i de unders $\varnothing$ gte dagtilbud.

"Jamen så har jeg det jo med på personalemøderne, og så snakker vi jo om, at det her... så har jeg et oplæg, og så kan vi tage en drøftelse af det og en snak om, hvordan vi kan prøve at integrere det her $i$ vores hverdag, for det er lige som med som en del af det arbejde, vi laver" (X-342-121).

Det skal dog også understreges, at mødeformen kan variere fra dagtilbud til dagtilbud, som det også kommer til udtryk i denne beskrivelse af de forskellige m $\varnothing$ deformer i et dagtilbud: 
"Postmøder det er hver anden fredag. Der kommer Y rundt. Postmøder det er der, hvor hun giver en lille status. Det er der vi er nu. Det er der, hvor en fra hver stue har mulighed for at tage noget med til postmødet, hvor de ved, at Y kommer rundt, hvis der er et eller andet, man lige vil spørge om, eller er i tvivl om. Det er ikke fordi, at vi ikke kommer rundt, men vi kommer ikke rundt hver dag. Stuemøder, det er stuerne selv. Det er praktiske ting. Det er der, hvor de lige sidder og snakker børn, og laver en handleplan over, hvad de nu skal osv. Husmøderne, det er det, der i gamle dage hed personalemøderne. Personalemøderne det er alle fire huse sammen ca. hver anden måned. En gang om året, der har vi en pædagogisk..."(Y-7-178).

I forlængelse af ovenstående citat, som er en fremstilling af de forskellige former for møder, har vi også i datamaterialet set en tendens til, at nogle dagtilbud arbejder målrettet og mere fokuseret med organiseringen af de formelle læringsformer, herunder mødet. Eksempelvis siger en leder, at:

"Vi er meget enige om, at vi holder nogle pædagogfaglige møder, hvor det kun er uddannede pædagoger, der deltager. Så holder vi almindelige personalem $\varnothing d e r$. Dem holder vi i dagtimerne, hvor husene indbyrdes hjælper med at passe børn. Det er de der møder, der ofte går hen, og er praktiske også. Hvem sørger for, at vi får $k \varnothing b t$ fastelavnstønder osv. Derfor har vi valgt, at vi holder nogle aftenmøder fra 17-20, som kun er for pædagoger, hvor vi debatterer og diskuterer vores mål og værdier og pædagogiske tiltag" (Y-2-24).

Det klassiske personalemøde er således i forandring og har sikkert været det i en del år, som vi ser i den skarpe opdeling mellem det almindelige personalem $\varnothing$ de og de mere fagligt udviklende diskussioner og refleksioner. Dataanalysen viser med tydelighed, at for nogle dagtilbud afholdes et møde ikke bare for mødets skyld, men tjener meget specifikke mål. Vi ser således, at vidensdeling sker gennem flere forskellige typer af møder her forstået som en formel læringsaktivitet. Hovedparten af citaterne understreger dog, at det stadig er personalem $\varnothing$ det, som er den primære mødeform i VIDA-Basis- og VIDA-Basis +-dagtilbud. En anden formel læringsmetode er inddragelse af ny viden og vidensdeling gennem uddannelsesforl $\varnothing \mathrm{b}$ og kurser samt oplæg internt i de respektive dagtilbud ved eksterne konsulenter eller inviterede eksperter om givne relevante emner og temaer. Denne læringsmetode bliver nævnt i 57 citater og er en af de primære i datamaterialet. På trods af variation i, hvordan de enkelte dagtilbud arbejder med uddannelse og interne oplæg, så er det specielt kurset, som er i centrum som den vigtigste læringsmetode som eksterne og interne videnskilder for dagtilbuddet. Det er sjældent, at vi i datamaterialet ser en egentlig strategisk anvendelse af mulig relevant viden fx internt i kommunen, hvorfor vi konstaterer, at det ofte 
er eksterne kurser, som er læringsmetoden her, som det kommer til udtryk i følgende typer: Kursusdeltagelse med to ansatte, sende st $\varnothing r$ re grupper af ansatte på kursus, sende ansatte på uddannelsesforl фb, generel kursusdeltagelse, kursusdeltagere laver hæfte, de andre kan orientere sig i, eksterne oplægsholdere, reflekterer over situationer med konsulent, viden ind fra kommunekonsulent, ringe til kommune for at få viden, få specialistviden ind fra eksterne folk, få specifik viden inden for særlige områder. Samlet set har vi lavet 27 koder for denne type læringsmetode og 57 citater (se boks 2 i bilag 1). Det er specielt deltagelsen på kurser, hovedparten af deltagerne omtaler som en læringsmetode, de anvender til at inddrage og få ny viden ind i deres dagtilbud.

"Vi gør rigtigt meget for at sende vores folk på kursus, så meget som muligt. Det er rigtig fint. De får proppet noget i hovedet, og så kommer de hjem og så skal de have muligheden for at videregive det, og det er dér, den trækker af" (Z-4101441-114).

"Der skal ruskes op hele tiden, og man skal på kursus og få fyldt på hele tiden. Når vi er på kursus, sender vi som regel to af sted, for at... det er nemmere at komme tilbage og få det givet videre, end at der er en der skal komme og..." (X-313-161).

Ovenstående to citater beskriver, hvordan informanterne anvender kurset som en måde at hente viden ind til institutionen udefra på. Kurset bliver et sted, hvor deltagerne får 'fyldt' ny viden på eksisterende viden. Det skal nævnes, at der helt konkret er en tæt kobling mellem deltagelse på kursus og det tidligere nævnte møde, da det ofte nævnes, at kursusdeltagere afrapporterer fra kursus på personalemødet. Et andet eksempel på at inddrage ny viden i dagtilbuddet er ved at hente eksterne specialister ind, som holder oplæg i institutionen om emner, som er af relevans i forhold til dagtilbuddets aktiviteter:

"Det tror jeg igen, er det samme med, at hvis man nu fx skal arbejde med farvelære, og man ikke ved noget om farvelære, så hiver man måske en kunstner ind i institutionen, eller man tager ud, og bliver klog på det" (Æ-4 010 542-172).

Den sidste læringsmetode inden for den mere formelle læringsform er læsning af litteratur. Denne kategori er tæt relateret til møder såvel som kursusdeltagelse og oplæg, da fx et oplæg fra en medarbejder til et personalemøde naturligt medfører læsning af relevant fagmateriale. Men vi har valgt at adskille læsning fra møder og kurser som læringsmetode i analysen, da det flere steder i datamaterialet fremstilles som en adskilt læringsaktivitet i forhold til at tilegne sig og inddrage ny viden. Efterfølgende præsenterer vi koderne (16) og antallet af citater (40) for denne læringsmetode, som i forhold til de to foregående læringsmetoder 
er kendetegnet ved en mindre forekomst (se boks 3 i bilag 1): Faglitteratur lægges frem, læse noget faglitteratur, læse og fælles refleksion, ny litteratur læses f $\varnothing \mathrm{r} m \phi$ der, ops $\varnothing$ ger relevant viden, alle ansatte skal have adgang til samme materiale, medarbejdere læser artikel og diskuterer, læser VIDA-mappe, læsning er nøglen, opdaterer viden og ekstra timer til at læse. Udsagn fra informanterne er typisk i forhold til læsning som inddragelse af viden:

"Så læser vi bøger og artikler, eller hvad det nu kan være, så vi har jo også en masse ting tilgængeligt, men man skal også lige vide, hvor man skal søge” (Z-2201316156).

Udsagnet er typisk for informanterne i forhold til denne læringsmetode. Et andet interessant tema er, at 'man skal også lige vide, hvor man skal søge'. Dette fremstiller en af udfordringerne ved denne læringsmetode, som består i at lokalisere den relevante og nødvendige viden. I den strukturerede læringsform får vi et svar på denne udfordring ved, at det er lederne, som lokaliserer og deler faglitteratur ud, som skal læses. En anden kobling i materialet er relationen mellem læsning og mødet. Ofte vil læsning af materiale være tæt knyttet til et møde, hvor det kræves, at der er læst som en del af forberedelsen.

\section{Informel læring}

Den anden kategori er den informelle læringsform. Den informelle læringsform bestemte vi til at være læring og vidensdeling, forstået som noget der opstår på baggrund af sociale interaktioner i en given praksis og fællesskab i forhold til løsning af arbejdsrelaterede aktiviteter. Informel læring består af to typer af læringsmetoder: netværk og medarbejderinteraktion. En overordnet analytisk betragtning er, at de informelle læringsmetoder fylder meget mindre i bevidstheden som aktiviteter for deling af viden og læring hos informanterne, hvis vi sammenligner med de formelle læringsmetoder. I datamaterialet kan man se, at medarbejderinteraktion har 12 analytiske koder og 15 citater, mens netværk samlet set har syv koder og 13 citater i alle fire unders $\varnothing$ gte kommuner (se boks 4 i bilag 1). Når medarbejderne taler om inddragelse og skabelse af viden fra informelle aktiviteter, er det primært om at gøre projekter sammen, lære i små grupper på stuen, måden man taler til hinanden i dagtilbuddet på, at pædagogerne selv anbefaler og finder litteratur, at personalet selv underviser hinanden fx ved praksisfortællinger og ved, at man reflekterer sammen i og efter konkrete situationer. 
"Når vi arbejder med projekter, kan vi også have projekter i hele huset. Her er det interessant, hvordan man bliver rystet sammen i personalegruppen ved at gå rundt og synes, det samme er spændende. Hvordan reagerer børnene, og hvad sker der nu?" (X-334-159).

Udsagnet viser, at læring og inddragelse af viden også sker gennem de mange projektarbejder, som personalet foretager i dagtilbuddet (som eksemplificeret efterfølgende, afsnit 4.3). I forhold til netværk bliver det af informanterne forstået som institutionsledernetværk, fredagsnetværksm $\varnothing$ der med udveksling af viden og erfaringer og netværkssamarbejde med andre fagligheder i tværfaglige sammenhænge i kommunen.

"Jeg har faktisk snakket med nogle af dem, som jeg er på VIDA+ sammen med, om, at i denne her tid, hvor der ikke er så mange penge i F Kommune, som der har været, så kunne vi måske bruge hinanden lidt mere til at komme ud og lave nogle af de her observationer og så snakke om, hvad det er vi ser" (Æ-4010577-155).

Ovenstående udsagn viser, at netværk for informanterne ikke kun er ledernetværk, men også kan være netværk, som opstår på baggrund af fælles faglige interesser. I dette tilfælde VIDA-projektets uddannelsesforl $\varnothing b$, som har skabt grobund for dannelsen af et netværk (se også kap. 2 og 3 i denne rapport). I datamaterialet finder vi også flere netværk mellem fx lederne i en kommune, som deler viden og erfaringer. En kommentar til den mindre forekomst af ovenstående læringsmetoder set i forhold til den formelle læringsform er, at vidensdeling og læring fra medarbejderinteraktioner ikke er en læringsmetode, som lederen altid vil få фje på, da det netop finder sted i praksis mellem medarbejdere. Derfor vil informanterne (lederne) ikke umiddelbart opleve, at medarbejderinteraktioner er vigtige læringsmetoder, hvor ny viden bliver inddraget. Inddragelsen af ny viden forstås primært som koblet eksplicit til de formelle læringsmetoder og er således ikke noget, lederne bevidst relaterer sig til.

Men samtidig er det netop i interaktioner i praksis, at den nye viden bevæger sig fra et konceptuelt niveau til et operationelt niveau og så at sige bidrager til, at dagtilbuddets praksisser over for børnegruppen udvikles og forandres. Derfor er det også - til trods for den lille forekomst af data - vigtigt at sætte fokus på de informelle læringsformer, da de tilknyttede læringsmetoder kan faciliteres ved at underst $\varnothing$ tte den kontekst og organisering, medarbejderne udf $\varnothing$ rer deres arbejde i. På den måde vil den informelle læringsform være tæt koblet til den strukturerede læringsform, der sætter fokus på den ramme, som alle udviklingsaktiviteter lægges ned i dagtilbuddene. På trods af den forholdsvis begrænsede forekomst 
af informel læring som bevidstgjort læringsmetode blandt informanterne, er det interessant at se 'netværk' indgå som en metode til at inddrage ny viden i VIDABasis- og VIDA-Basis +-dagtilbud, da det i de pågældende dagtilbud indikerer en ekspliciteret åbenhed over for omgivelserne og den viden og de erfaringer, som findes her.

Det skal til både medarbejderinteraktion og netværk som læringsmetoder siges, at de i dataanalysen primært forekommer i kommunerne Y og $Æ$, mens forekomsten er meget lille i X og Z, når vi måler på antallet af citater, dvs. steder, hvor informanterne har svaret, at de arbejder med pågældende læringsmetode (se bilag 2). Denne observation er ikke udtryk for statistisk signifikans, men fordelingen peger på en tendens til, at nogle kommuner er mere opmærksomme på udvikling af viden og læring på basis af informelle aktiviteter end andre, og at informelle læringsmetoder kan bidrage til dagtilbuddenes inddragelse af ny viden.

\section{Læringskonteksten}

Den tredje kategori er rammen for den formelle og informelle læring, som vi kalder for læringskonteksten. Læringskonteksten handler om strategiske organiseringer af arbejdet gennemf $\varnothing \mathrm{rt}$ af lederen. Eksempelvis vil det at medarbejderudviklingssamtalen (MUS) nævnes, indikere, at lederen og hele organisationen har valgt at medtænke MUS som en automatisk del af det at dele viden og skabe grundlag for læring. Et andet eksempel er personalem $\varnothing$ det som organiseringsform, som fungerer som en strategisk platform for inddragelse af ny viden for nogle ledere. Dette kunne ske gennem den tidligere viste opdeling af personalemødet i en praktisk og faglig del.

Læringskonteksten er kendetegnet ved følgende metoder: Lederen filtrerer viden for medarbejderne, lederen faciliterer aktiviteter, virksomhedsplaner beskriver, hvordan der arbejdes med inddragelse af viden, lederen fors $\varnothing$ ger at få egen motivation til at smitte af på medarbejderne, lederen styrer, hvad der skal læses, lederen foretager 'stuegang' og starter dialog med personalet på konkrete cases, lederen målretter mødet mod behov for viden i dagtilbuddet, strategisk kompetenceudvikling, overordnet strategi for udvikling af dagtilbuddet, og hvordan viden inddrages, målrettet udvikling, og at MUS-samtalen bruges som instrument til at skabe læring. Samlet set er der 39 koder og 57 citater, som danner grundlag for struktureret læring, hvor vi har valgt at samle de lederstyrede og organiserede læringsmetoder sammen, da de er tæt relaterede (se boks 5 i bilag 1). Et eksempel på, hvordan lederen kan arbejde med at organisere videndeling og læring, ser vi i følgende: 
"Men sådan helt konkret så har vi fælles personalemøder, hvor jeg præsenterer et eller andet eller jeg har hyret en ind til at sige noget om det. Og så laver vi proces på det - cafedrøftelse, både i det fælles men sørger hele tiden for, at tingene følges op. Altså det vil sige, at lancerer vi et eller andet og det er egentlig dybest set ligegyldigt hvad det er. Så sikrer vi altid, på de efterfølgende mødefora eller i de processer der bliver skabt, at der bliver tingene fulgt op. Jeg er rigtig opmærksom på at tingene ikke bare får lov til at dø ud. Der er ikke noget så demotiverende som - og hvad skal jeg så bruge det til? Så på den måde er der en meget målrettet struktur på det, vi gør" (Y-14-157).

Uddraget fra datamaterialet handler om, hvordan lederen organiserer personalemødet. Lederen oplever personalem $\varnothing$ det som en proces, fra f $\varnothing \mathrm{r}$ m $\varnothing$ det starter til selve gennemf $\varnothing$ relsen af mødet og fastholdelse af ny viden efter mødet. I stedet for bare at nævne mødet, så har denne informant organiseret mødet på en måde, som underst $\varnothing$ tter inddragelsen af viden. På denne måde bliver mødet til mere end alene formel læring med læsning i forhold til en dagsorden, ved at mødet organiseres på en målrettet måde.

Det overordnede resultat fra analysen af ledelsesstyring og organisering er endvidere, at vi ser en markant skævhed i datamaterialet. Det er specielt kommune Y, som indikerer, at de arbejder eksplicit med en strategisk og struktureret styring af inddragelse af viden og læring, mens forekomsten er betydeligt mindre i de $\varnothing$ vrige kommuner. I kommune Y finder vi 26 analytiske koder og 36 citater. Vi har valgt at udelade læringsmetoden 'teknologi' fra ovenstående analyse, da forekomsten dels er minimal, og dels at vi ikke opfatter denne læringsmetode som direkte koblet til ledelse og organisering af vidensprocesserne. Vi ser dog stadig anvendelsen af teknologier som en del af læringskonteksten, da den i høj grad indeholder et potentiale i forhold til at skabe en ramme og et instrument, der kan underst $\varnothing$ tte inddragelsen af viden i de unders $\varnothing$ gte dagtilbud. Teknologi refererer primært til internettet som en teknologi, nogle få informanter anvender til at lokalisere informationer og viden. Der er tre analytiske koder og tre citater, som nævner teknologi som en læringsmetode. Naturligvis indgår teknologier i alle aktiviteter i dagtilbud i dag på den ene eller anden måde, men i denne undersøgelse har vi været interesseret i at få VIDA-Basis- og VIDA-Basis +-ledernes umiddelbare oplevelse af, hvordan de konkret arbejder med inddragelse af viden og skabelse af læring i organisationen, og i den sammenhæng har teknologi ikke været noget, informanterne eksplicit har tillagt betydning. Dette er interessant, da der i VIDA-programmet netop er lagt op til at arbejde teknologibaseret med netværksdannelser og refleksion gennem bl.a. den digitale platform SharePoint (se VIDA-statusrapport 1, Jensen et al., 2011a, kap. 2). 


\section{TEMATIKKER FOR KVALITET I PÆDAGOGISK ARBEJDE}

Til at besvare spørgsmålet om, hvordan lederen st $\varnothing$ tter sine pædagogiske medarbejdere i at udvikle kvalitet i det pædagogiske arbejde, har vi i analysen identificeret, hvilke konkrete aktiviteter lederne i de unders $\varnothing$ gte dagtilbud anvender. Hvor den foregående analyse havde fokus på, hvilke konkrete læringsmetoder, lederne benyttede sig af, så er denne analyse mere rettet mod grundlæggende mønstre eller tematikker i datamaterialet, som handler om faciliteringen af det pædagogiske arbejde i VIDA-Basis- og VIDA-Basis +-dagtilbud. Det skal nævnes, at nogle kategorier fra den foregående analyse naturligvis vil gå igen, da informanterne i selve interviewet lige har berørt emnet i forhold til det konkrete arbejde med inddragelse af viden, men også fordi nogle aktiviteter er sammenfaldende mht. konkrete måder at inddrage viden på og skabelse af kvalitet i det pædagogiske arbejde.

Når man vurderer den samlede dataanalyse, fremstår der en central og tilbagevendende tematik omkring lederens rolle i forhold til at skabe grundlag for deling af viden og skabelse af kvalitet. Vi så i den foregående analyse, at lederstyring og organisering af konkrete indsatser for nogle var et centralt kendetegn ved deres arbejde med udvikling af dagtilbud. Dette betegner vi som en strategisk orienteret måde at arbejde med ledelse af viden og læring på i de unders $\varnothing$ gte dagtilbud. For andre er den strategiske dimension ikke tydeliggjort i deres udsagn i samme grad. I dataanalysen er alle interview blevet karakteriseret ud fra, i hvor høj grad lederen og lederens dagtilbud fremstår som et sted, hvor der bliver arbejdet på en 'strategisk' henholdsvis 'ikke-strategisk' måde med en mellemform, som i analysen er blevet betegnet 'mellemstrategisk'.

En strategisk orienteret profil kendetegner dagtilbud, som arbejder målrettet med forskellige lærings- og udviklingsmetoder samt organiseringsformer. Udviklings- og læringstiltag for de enkelte ansatte, grupper (team) af ansatte eller hele dagtilbuddet sættes for de strategisk orienterede dagtilbud i gang, således at de kan imødegå og realisere ekspliciterede målsætninger, manglende kompetencer, visioner, krav eller behov etc. To eksempler på en strategisk orienteret indsats ser vi i følgende udsagn. Det skal nævnes, at alle kommunerne oplever forekomst af strategiske, ikke-strategiske og mellemstrategiske former, hvorfor udsagnene er valgt tilfældigt ud fra materialet:

"Altså jeg bruger jo også MUS-samtaler og så følger vi op på...

Interviewer: Og det er alle

medarbejdere? 
Interviewperson: Ja, så følger vi lidt op på den enkelte medarbejder og vi aftaler om vi skal mødes om 3 måneder, 6 måneder eller et år. Men det gør jeg også. Og så $i$ dagligdagen" (Z-4201415-162).

"Det har jeg hvert andet år. Og så hvert andet år medarbejderudviklingssamtaler. Det er i hvert fald det, jeg gerne vil og det har jeg også praktiseret... Og så skal de jo målsætte, hvad er det vi vil, hvad er det vi har fokus på-også med læreplansarbejdet, det skal de jo arbejde med på deres teammøder og deres stuemøder. Jeg vil gerne væk fra at det skal hedde stue. Jeg prøver, det er svært.

I: Hvad kalder du det så?

IP: Grupper og team og afdelinger.

I: Og hvad er der i vejen med at kalde det stuer?

IP: Det er ikke så dynamisk man bliver mere fastlåst i tænkningen, når det hedder stuer, for det har det jo heddet gennem de sidste 40-50 år. Og man låser sig lidt om sig selv og siger, det er vores stue. Og jeg vil meget hellere have at man ude $i$ afdelingerne siger, hvad har børnene brug for og hvilke grupper kan vi lave, der giver mening for dem? Det er i hvert fald det vi prøver på” (Y-9-243).

Vi ser i begge udsagn tydelige indikationer på, at lederen gør sig tydelige overvejelser omkring styringen af en given aktivitet og i det sidste eksempel også har et fremtidigt perspektiv lagt ned over besvarelsen. En ikke-strategisk profil arbejder med udvikling på et mere intuitivt eller implicit baseret grundlag og vil i forhold til ovennævnte udsagn ikke indeholde eksplicitte overvejelser. Ofte bliver baggrunden for arbejdet med kvalitet i den ikke-strategiske form nævnt, uden at det kobles til eksplicit definerede behov, mål, фnsker el. lign. i dagtilbuddet. Formen 'mellemstrategisk' befinder sig mellem en eksplicit strategisk tilgang og en mere intuitiv måde at arbejde med kvalitet på i dagtilbud. I hele datamaterialet har vi fundet 13 dagtilbud, som viser tegn på at være strategisk orienterede, 22 mellemstrategiske dagtilbud og endelig 34 ikke-strategiske.

En anden tematik i forhold til at arbejde med at skabe kvalitet i det pædagogiske arbejde ser vi i graden af sammensathed i forhold til anvendelsen af metoder. Med forskellig grad af sammensathed refererer vi til bredden af forskellige metoder til at skabe vidensdeling og kvalitet i de unders $\varnothing$ gte dagtilbud. Nogle informanter beskriver, at de arbejder med meget få metoder til at skabe kvalitet, mens andre beskriver en mangfoldighed af anvendte metoder, som er udtryk for en st $\varnothing$ rre bredde og mere sammensathed. I et interview ser vi fx, at informanten på spørgsmålet om, hvordan informanten oplever, at der arbejdes med at skabe kvalitet, svarer: 
"Med kurser fx XXXX-kurser for pædagogerne, og så er der sådan et ugekursus, som medhjælperne også kan komme på. Der er så godt nok kun én, som har kommet på nu. Men jeg har faktisk også lige søgt om kompetencemidler også, og har fået tildelt et projekt $i$ institutionen om at videreudvikle XXXX og den anerkendende tankegang" (X-330-164).

Kurset beskrives af informanten som den eneste metode, de i det pågældende dagtilbud anvender til at st $\varnothing$ tte de pædagogiske medarbejdere i at skabe kvalitet. Et eksempel på en mere sammensat tilgang ser vi hos informanter, som beskriver en bred palet af metoder fx MUS-samtaler, teamsamtaler, netværk, ledersparring, kursusdeltagelse etc. På denne måde er der variation i graden af metoder til udvikling af kvaliteten af det pædagogiske arbejde gående fra enkeltmetoder til dagtilbud, der anvender flere metoder og tilgange.

En tredje tematik, som bliver nævnt af flere informanter, er brugen af ledersparring i forbindelse med udvikling af kvalitet. Ledersparring refererer til forskellige former for interaktion mellem leder og medarbejder, som kan være ledersupervision af medarbejdere, lederen er på 'pletten' i praksis og sparrer med personalet på faglige cases. Sparring bliver i dette tilfælde en tematik, der drejer omkring kommunikationsformer mellem leder og medarbejdere i dagtilbuddet, som andet end at lederen tager styringen og sætter krav og mål, men at leder og medarbejdere indgår i en åben og gensidig relation. Hermed understreges vigtigheden af dialogen og det at lytte til medarbejdernes udfordringer som afsæt for at skabe udvikling. Et godt eksempel på ledersparring fremstilles i følgende udsagn:

"Det jeg har gjort eksempelvis med læreplaner, der har jeg, når de har afsluttet et tema, så tager jeg med på evalueringsmøderne, og jeg er med til at prøve at give noget input til, hvordan skal man tænke det her. Hvad fik de ud af det, gjorde I nogle ting, prøv at fokusere på..., så det ikke bliver intetsigende, prøve at sige, hvad kan vi lære, hvad kan vi bruge den ny viden til, som vi har skabt nu her, fordi de har alle svarene, men det er ikke altid de har formuleringerne eller tanken om at spørge på den måde. Det gør jeg rigtig meget, for at skabe noget refleksion, og få dem til at tænke over nogle ting. Jeg prøver at spørge ind til alt muligt, når I nu siger det der, hvad gjorde I så. Nu sagde du, at det der var rigtig, rigtig godt, hvordan var det så godt. Prøve at give dem alle de her refleksionstilgange, kan man sige" (Y-1-144).

I udsagnet beskriver informanten, hvordan denne arbejder med at få videreført og gjort den viden, medarbejderne har arbejdet med på møder, til noget meningsfyldt. Dette sker ved, at informanten stiller spørgsmål omkring temaet, som medarbejderne har haft oppe, for at igangsætte refleksive processer og dermed 
også st $\varnothing t t e ~ u d v i k l i n g$ af det pædagogiske arbejde. Vi ser således to roller, som lederen indtager i de unders $\varnothing$ gte tilbud. På den ene side er der den strategiske leder, som sætter fokus på at kommunikere tydeligt, sætte mål og eksplicit forfølge disse mål med relevante metoder. På den anden side ser vi den lyttende leder, som arbejder med åben kommunikation i form af forskellige typer af sparring med de pædagogiske medarbejdere. Man kan betegne disse to roller som rettet mod at skabe resultater og mening i de unders $\varnothing$ gte dagtilbud, men med forskellig tilgang hertil.

Samlet set viser analysen i forhold til lederens konkrete arbejde med at inddrage viden og skabe læring, at de primært anvendte læringsmetoder er de formelle. Specielt anvendt er mødet i forskellig form, efterfulgt af kursusaktivitet og læsning af faglig litteratur. De mere informelle læringsformer er kun i mindre omfang ekspliciteret af informanterne som en decideret læringsmetode. Konteksten for de forskellige læringsmetoder er også fremhævet af informanterne som en vigtig faktor i deres arbejde med konkret inddragelse af viden og læring i dagtilbud.

I forhold til at udvikle kvalitet i det pædagogiske arbejde ser vi primært tre tilbagevendende tematikker gøre sig gældende. Den ene tematik handlede om den strategiske adfærd, som for nogle informanter har stor betydning, mens det for flere gælder, at de står i en mellemposition eller arbejder ikke-strategisk. Den anden tematik handlede om graden af sammensathed i informanternes opfattelse af, hvordan de arbejder med at skabe udvikling i deres dagtilbud. Her varierer det fra nogle dagtilbud, som benytter sig af få metoder, til andre, som bruger en bred palet af metoder til at skabe udvikling. Den tredje tematik retter fokus mod lederens rolle som kommunikator og facilitator af medarbejdernes refleksionsprocesser og indtager rollen som supervisor eller sparringspartner.

\subsection{EKSISTERENDE PAEDAGOGISKE PRAKSISSER OG FAKTORER AF BETYDNING}

I det følgende afsnit bliver to spørgsmål belyst:

- Hvordan er den eksisterende praksis i VIDA-dagtilbud i udgangspunktet med hensyn til læring, trivsel og social inklusion, generelt og specifikt rettet imod socialt udsatte børn? 
- Hvilke fremmende og hæmmende faktorer fremhæver lederne som udfordringer i arbejdet med udsatte børn? Og videre i forlængelse heraf: Hvad er ledernes opfattelse af og forventninger til, at VIDA kan gøre en forskel?

I relation til det første spørgsmål, fandt vi i baseline-analysen i Statusrapport 2 (Jensen et al., 2011b, kap. 2), at ca. halvdelen af deltagende institutioner lægger det pædagogiske arbejde tilrette ud fra en bestemt pædagogisk teori. Dette betyder, at halvdelen ikke arbejder teoribaseret. Spфrgsmålet bliver mere dybtgående belyst ved at interviewe samtlige deltagende ledere om deres begreber om a) læring og trivsel og b) social inklusion samt ledernes beskrivelse af c) gode erfaringer med aktiviteter i praksis, som bygger på disse begreber. I analysen bliver der lagt vægt på at identificere, hvordan ledere italesætter disse begreber, i hvilken grad der kan identificeres et vidensbaseret teoretisk grundlag for praksis, og i hvilken grad grundlaget er mere intuitivt. Det intuitive er udtryk for, som vi så i forrige afsnit, at dagtilbuddet arbejder mere erfaringsbaseret. I denne del af unders $\varnothing$ gelsen er der spurgt dybere ind til, hvilke refleksioner ledere g $\varnothing$ r sig i den sammenhæng.

I relation til det andet spørgsmål om, hvilke udfordringer lederen står med i relation til arbejdet med udsatte børn, vil interessen samle sig om, hvorvidt udfordringer og måder at beskrive institutionernes håndteringsmåder af eventuelle udfordringer på hænger sammen med ledelsesstrategi og læringsformer. Det vil sige, vi фnsker at se på, hvilke forhold der italesættes som faktorer, der kan hindre implementering $i$ at ske, og hvad lederne selv oplever, supporterer dem i professionsfagligt perspektiv. I denne sammenhæng ser vi også på ledernes forventninger til VIDA, der i VIDA-Basis- og VIDA-Basis +-uddannelsen tænkes at være en st $\varnothing$ tte for ledernes arbejde med at styrke det samlede dagtilbuds faglighed og anvende ny viden som forandringskilde.

\section{AKTIVITETER TIL FREMME AF B $\varnothing$ RNS LÆRING OG TRIVSEL GENNEM INKLUSION}

Den generelle tendens, som analysen viser, er, at lederne på tværs af de fire kommuner alle har fokus på, at arbejdet med socialt udsatte børn er en del af dagtilbuddets samlede kerneopgave. Der er til gengæld forskel på, om der fokuseres på et teoretisk begreb om læring, trivsel og inklusion, et erfaringsbaseret begreb eller et mere intuitivt begreb om læring set i relation til barnets behov. Fælles for institutionerne er, at der ikke skelnes mellem børn generelt og udsatte børn, når der tales om at arbejde med kvalitet i dagtilbuddet. Men når spørgsmålet lidt mere specifikt drejer sig om `Hvad sætter I fokus på i arbejdet med udsatte 
børn?' og 'Hvilke erfaringer har I med hensyn til at arbejde med læring, trivsel og inklusion i relation til udsatte børn?', differentieres svarene i nogle grundformer, som træder frem i dataanalysen.

På baggrund af analysen af svarene fra lederne fremstår tre grundformer for pædagogisk praksis knyttet til at arbejde med børns læring og trivsel. Disse er identificeret ud fra den måde, lederne beskriver baggrunden for det pædagogiske arbejde og de mere konkrete aktiviteter på, der knytter sig til arbejdet. De tre grundformer, der belyses her, er:

I. At opfatte læring som et særligt mål, der skelnes mellem læring og trivsel, og der arbejdes teoribaseret.

II. At opfatte læring og trivsel som sammenhængende mål, og læring er ikke specifikt defineret. Der arbejdes ikke ud fra en teoretisk tilgang.

III. At opfatte læring som nyt og ikke en integreret del af den pædagogiske praksis.

I: I At opfatte læring som et særligt mål, der skelnes mellem læring og trivsel, og der arbejdes teoribaseret

Vi ser eksempler på, at i disse dagtilbud ekspliciterer lederen, at man bygger pædagogikken på en teori, fx en teori om 'zonen for nærmeste udvikling' jf. Vygotsky. Det forklares, at pædagogikken bygges op som en progression i temaer, projekter og længerevarende forl $\varnothing b$, hvor børnenes læring og udvikling følges. Mål opstilles, processen følges, og resultater evalueres. Vi ser også eksempler på dagtilbud, der opbygger arbejdet med børns udvikling ud fra en teori om 'anerkendende' pædagogik ud fra et konkret koncept, ICDP (International Child Development Program). Lederne, der beretter om, at de arbejder med ICDP-programmet, beskriver, at det drejer sig om at udvikle kommunikationen mellem barnet og dets omsorgspersoner. Desuden tager forløbet med at arbejde med ICDP udgangspunkt i barnets kulturelt betingede ressourcer. Personerne omkring barnet skal bl.a. udvikle deres bevidsthed om, hvordan de praktiserer en række samspilstemaer. Data viser, at især en af deltagerkommunerne har opbygget erfaringer med at arbejde pædagogisk med denne teoretiske tilgang, hvilket viser sig ved, at denne gruppe er repræsenteret inden for en gruppe af dagtilbud, der i udgangspunktet har gode erfaringer med at arbejde teoribaseret. 
Men også andre deltagere på tværs af kommunerne arbejder teoribaseret. Dette er imidlertid mere individuelt bestemt fra leder til leder og ser ud til at afhænge af det samlede dagtilbuds faglige kapacitet og фvrige læringsformer og læringsmetoder, der tages i anvendelse. Læringsformer og metoder, som blev identificeret i forrige afsnit, kan genfindes i denne del af analysen. Nogle ledere fortæller fx, at der arbejdes tematisk med bl.a. temaerne: "fri for mobberi", "kammerater", "vind og vejr", "former, farver, begrebsudvikling, tal, bogstaver og mere styret undervisning og pædagogik" og "skoven, samle blade" - og andre ledere beretter om en pædagogik, der planlægges som temaer, som er styrende for arbejdet med alle børns læring i en periode. Et sådant forl $\varnothing \mathrm{b}$ kan fx være "mig selv, min familie, min by" (Z 4301-407) eller det at arbejde med H.C. Andersens "R $\varnothing$ dhætte og ulven og så tages aktiviteter med ind hele vejen rundt" (Z-4301-434).

II. At opfatte læring og trivsel som sammenhængende mål og læring, er ikke specifikt defineret. Der arbejdes ikke ud fra en teoretisk tilgang.

Det, der kendetegner denne gruppe, er, at der ikke arbejdes teoribaseret, men mere erfaringsbaseret med læring. Dette viser sig ved, at begrebet læring ikke er eksplicit defineret. Lederen arbejder med læring og trivsel ud fra aktiviteter, der er mere bredt orienteret og inspireret af loven om pædagogiske læreplaner. Læring opfattes som et nyt begreb og som et begreb, der er vanskeligt at definere. Tendensen er inden for denne gruppe således, at lederne ikke definerer læring, men arbejder med læring ud fra den aftale, man har med kommunen om pædagogiske læreplaner. Der arbejdes fx med bundne opgaver såsom sprogvurderinger, motorikvurderinger, eller helt dagligdags ting som at sidde rigtigt ved bordet, lære at spise osv.

III. At opfatte læring som nyt og ikke en integreret del af den pædagogiske praksis

Lederen kan fx melde ud, at: "Nu er jeg helt blank" (Æ 4010-579/581) adspurgt om, hvordan dagtilbuddet arbejder med læring og hvilke aktiviteter, man har gode erfaringer med. Informanten beretter selv, at informanten ikke "føler sig fagligt klædt på til at arbejde med læringsopgaven". Andre tager mere eksplicit afstand fra læringsbegrebet, "vi har forholdsvis få planlagte aktiviteter, vi har ikke noget med, at man skal møde før kl. 9" (Z 4101-417), og en af grundene er ifølge denne informant, at "familien jo sidder ude på bænkene om aftenen og man skal ikke smide de små børn i seng, så de kommer i børnehave kl. 10-10.30" (ibid.). En anden leder fortæller: "Det er ren brandslukning, hvis et eller flere børn har det svært, så når vi ikke vores planlagte pædagogiske virksomhed, fordi vi er nødt til at dykke ned i almindelig tryghed og omsorg, og det er jo så træls at man 
ikke kan gå videre med det man egentlig gerne ville-arbejde $\mathrm{i}$ længere tid med et tematisk forløb" (X 317).

Eller for at tage et andet yderpunkt er der identificeret eksempler på ledere, der tager direkte afstand fra læringsbegrebet. Fx siger en leder, at læring og aktiviteter, der fremmer læring, er "nogle grimme ord, du nævner i forhold til pædagogik. Ja det er ikke den gamle ting med, at nu skal pædagoger lære fra sig, at pædagoger skal give omsorg, men nu er læreplanerne endelig ved at få tag på pædagogers faglighed" (Z 4301-436).

Lederen, der er interviewet her, er egentlig ikke modstander af læreplaner og siger også, at "vi arbejder lovgivningsmæssigt i forhold til læreplanerne, men vi har 75 børnehavebørn og vi er først nu ved at finde vores plads i forhold til læreplanstemaerne" (ibid.). Men i den sidstnævnte institution er man nu ved at arbejde innovativt, dvs., lederen taler om at skabe værdiforøgelse ved at arbejde på nye, kreative måder med læreplanerne. Vi "skal skabe overskud, ikke ved at løbe hurtigere, men vi har lavet en 'plusgruppe' hvor vi tager specielt fokus på de børn der har det svært. Hver dag i en måned, fx går en lille gruppe ud af huset. På en måned kan denne gruppe opleve noget som de aldrig har oplevet, set eller mærket, fra intellekt til fysik".

\section{GRUNDFORMER FOR PÆDAGOGISK PRAKSIS}

Der er således som vist en række forskelle på den måde, der arbejdes med børns læring og trivsel i dagtilbuddet på. Vi vil derfor indkredse forskellene og substansen på de tre grundformer for pædagogisk praksis, som er skitseret ovenfor, og de strategier, som kan udledes af ledernes beskrivelser af deres konkrete praksis. Hensigten er for det $\varnothing \varnothing$ rste at identificere den enkelte tilgang baseret på analysen af ledernes egne udsagn. For det andet er det hensigten at gøre tilgangen tydeligere ved at se den i et bredere læringsteoretisk perspektiv og samle den i en model, som skal knyttes til de tematikker, der blev anslået i kapitlets andet afsnit (4.2). Vi unders $\varnothing$ ger således i dataanalysen, om der er der noget, der samler, og om der er forskelle, og hvori de i givet fald består.

På baggrund af de deskriptive analyser af interview med lederne fremstår tre grundformer for pædagogisk praksis i de unders $\varnothing$ gte dagtilbud: 1) Institutioner præget af ekspliciteret, teoribaseret tilgang til opgaven - repræsenterer en formel og strategisk læringsform og er karakteriseret ved, at lederen beskriver medarbejderne som en medarbejderstab, og der arbejdes målrettet og systematisk med børnenes læring. 2) Institutioner præget af en erfaringsbaseret tilgang til opga- 
ven - er karakteriseret ved en stræben efter at højne faglighed og arbejde med en unders $\varnothing$ gende læringsform. Der er stor lyst til og behov for at blive mere bevidst om faglige begreber og et udtalt $\varnothing$ nske om at indarbejde refleksion mere i relation til praksis som en del af arbejdsopgaven i hverdagen fremover og blive bedre til det. 3) Institutioner præget af en behovsbaseret tilgang - er karakteriseret ved vaner samt en rutinepræget pædagogisk praksis og tilhørende læringsform. Der er lyst til, men ikke stor tro på, at det at ændre praksis kan gennemføres, idet de ofte oplever rutiner som ikke-foranderlige. Praksis opbygges 'ad hoc' - man griber dagen og tager udgangspunkt i det enkelte barns behov, som det udmønter sig den pågældende dag. Vi beskriver i det følgende mere indgående indholdet i de tre forskellige pædagogiske grundformer for praksis, som det er kommet til udtryk i de gennemførte lederinterview, og fremstiller således de empiriske fund, der danner baggrund for de tre grundformer.

\section{Teoribaseret læringsorienteret praksis}

"En pædagogisk kontekst rettet imod barnets ressourcer"

"Vi tager udgangspunkt i det enkelte barn, hvor det er og viser sig at være stærkt, og så sætter vi fokus på at skabe et miljø, hvor det normale har vide grænser. Vi kan se, at vi rummer 'mange pudsige børn'. De sociale kompetencer er vi meget bevidste om at arbejde med, da man simpelthen ikke kan få et godt liv uden" (X 304). Lederen er i denne grundform fokuseret på, hvordan læring i den sociale kontekst finder sted, og lægger desuden vægt på, at alle seks læreplanstemaer fra loven om pædagogiske læreplaner skal i spil - og sættes i en sammenhæng med det sociale. Der lægges vægt på ressourcer og den pædagogiske kontekst, og hvordan individ og kontekst spiller sammen. Dette stiller krav til de voksne om at "kunne have et фje på hver finger". De voksne skal kunne spotte, hvad barnet faktisk er stærk til, og skal kunne tilrettelægge aktiviteter med de andre børn, så barnets styrker og ressourcer kommer i anvendelse. Et tema, som lederen fortæller, at de har succes med, er:

"Matematik, det går på alt, man bager boller, vejer, måler, måler skridt, højde, sidder i en oval, som man så skal flytte sig rundt fra så bliver det en cirkel osv. Børnene lærer at sammenligne mængder, de voksne sætter i gang, men børnene gør det også selv, tager initiativ og går videre".

Som et særligt fund fremhæver lederen, at de udsatte børn også kan profitere af det, de oplever således at forstå, at lige præcis matematik kan være mere konkret end blot at være en 'god ven'. Det at lære om venskaber, sociale kompetencer og kommunikation sprogligt kan være "komplekst", og som lederen (X-304) siger: 
"Nogen børn kan godt have en klodset tilgang til at komme ind i en leg, de risikerer et nej fordi de ikke gør det elegant nok, men i matematik kan de sige: "Wow, jeg er dygtig til det her'”'. Eksemplet viser, at lederen har en fokuseret og teoretisk baseret opmærksomhed på de muligheder, der ligger i en pædagogisk kontekst, der satser på læring, og denne indsigt er også baseret på viden og bevidsthed om, at denne situation ikke kommer 'af sig selv'. Læringsrummet skal opdages, skabes og vedligeholdes. Her kommer den voksnes rolle og pædagogiske faglighed i centrum, og lederen er helt bevidst om dette betydningsfulde - mødet med den voksne, der ser barnet og får øje på potentialerne.

Som identificeret i samtlige interview, der kan karakteriseres inden for denne teoribaserede læringstilgang, knytter et ressourcesyn på opgaven vedrørende arbejdet med socialt udsatte børn sig til en bevidsthed om betydningen af faglighed og organisering og struktur som en slags læringskultur i dagtilbuddet. Som en leder beskriver det, arbejdes der med "læring ud fra barnets nærmeste udviklingszone og der sættes fokus på at der skal sættes målsætninger for grupper af børn og for formidling til forældre" (Y-14a).

Det vigtige er ifølge lederen "at arbejde med emner som børnene føler sig optagede af og vi tænker børnehaven som et stort læringsrum". Der arbejdes med projekter og emner, og alle medarbejdere sættes i gang ud fra princippet "ud af hovedet og ned på gulvet", samtidig med at der lægges vægt på organisering, som bl.a. kan genkendes ved, at hvert barn har sin egen private pædagog. Lederen er opmærksom på, at børns læring er tæt forbundet med den sociale kontekst, og at den private pædagog er en måde at sikre børn tryghed på og dermed højne barnets trivsel og læring.

Lederen lægger endvidere stor vægt på organisering og stiller krav til medarbejderne om, at de skal gå "fra at handle på det ureflekterede til at handle ud fra refleksioner" (Y-14a). Vi ser i eksemplet, at det at arbejde teoribaseret knytter sig til at arbejde med $h \varnothing j$ faglighed, vidensbaseret og ud fra den læringsform og -metode, som vi i det tidligere afsnit har kaldt 'formel og strategisk'. Der er helt tydeligt en sammenhæng mellem denne form for faglighed og det at arbejde teoribaseret med en strategisk læringstilgang. Målet er, at "børn skal være selvhjulpne, være nysgerrigt udforskende, skal have mere viden, livsduelighed, og kunne tilegne sig en positiv tilgang til at tilegne sig ny viden" (ibid.).

Begge eksempler vidner om, at det at arbejde teoribaseret med indsatsen for socialt udsatte børn i dagtilbuddet er bygget op om en klar bevidsthed om, hvilket læringsbegreb det er relevant at bygge på - nemlig et begreb, der sikrer barnets 
trivsel gennem læreprocessen og skelner læring fra trivsel. Endvidere er det tydeligt i de eksempler, der er identificeret i materialet (i alt i ca. 1/3 af alle de inddragede dagtilbud), at der arbejdes målrettet med børns læring. Det er også tydeligt, at den sociale kontekst, daginstitutionens læringsmilj $\varnothing$ tænkes med og omgivelserne i det hele taget, ses som ramme om børns læring.

Det, der er fælles for dagtilbud, der arbejder fokuseret ud fra en teoribaseret læringstilgang, er, at man arbejder systematisk og målrettet med planlægning af den pædagogiske praksis, opstiller målsætninger og evaluerer løbende. Desuden vægtes faglighed i dagtilbuddet højt, og højnelse af medarbejdernes kompetencer er helt centralt. Endelig lægges der, som eksemplificeret ovenfor, vægt på organisering og struktur, og dette sikres ved ledelsesstyring. Som eksemplificeret i sidstnævnte case udtaler lederen netop, at der skal skabes sammenhæng, og man skal som ledelse sikre 'den røde tråd'. "Vi er nødt til at være en ledelse, der siger det er den vej vi skal gå-ellers mister vi vore medarbejdere" (Y-14a).

\section{Erfaringsbaseret læringsorienteret praksis}

"Vi arbejder med anerkendende pædagogik, men 'fejlfinding er stadig en del af hverdagen. Vi er ikke super gode til det med læring" (Z 4101-441).

Udsagnet stammer fra en leder, der oplever, at der ligger en stor opgave i at arbejde med læring og trivsel relateret til alle børn og udsatte børn i særdeleshed. Institutionen er placeret i et udsat område med mange udsatte børn (af 20 børn er der fire med diagnoser, to med udredningssager, mens resten har sociale problemer). De udsatte børn og deres problemer har afsmittende virkning på de andre børn og på pædagogikken i det hele taget. En anden leder fortæller, at de arbejder med at observere det enkelte barn og arbejder sådan "lidt hospitalsagtigt" (Z-4101-442). Det, der er i fokus i disse institutioner, er udsatte børns problemer, og ofte ser vi eksempler på en 'fejlfindingstilgang'. If $\varnothing$ lge lederne selv $\varnothing$ nsker man at gribe det anderledes an, men flere fremhæver, at det er svært at "slippe den der fejlfinding". Man har ikke teoretiske begreber at læne sig op ad eller bygge på, så det bliver erfaringer og rutinerne, der tager over, når praksis melder sig. Institutioner, der er identificeret inden for kategorien "at arbejde erfaringsbaseret", de ved 'på rygraden', hvad der fungerer godt og virker, men har ikke begreber for det, man gør mht. læring og trivsel. Institutionerne har således svært ved at italesætte det, man gør, som flere udtrykker det.

Pædagogikken i dagtilbud, der arbejder erfaringsbaseret med børns læring, er, at de arbejder i temaer og ofte korte forl $\varnothing b$, og har ikke planlægning af st $\varnothing$ rre sam- 
menhængende læringstiltag. Fx taler en leder om, at børn skal have hjælp til "deres udvikling, motorik, den sociale udvikling, helt ned hvor vi snakker opdragelse, adfærd, hvad man gør og ikke gør, 'fumlere - tumlere”' osv. (Æ- 2010-568). Her arbejdes med motorikvurdering, sprogvurdering, fællesskaber og andre gange noget kreativt, bruge sin krop, bygger huler. Der er tale om korte forl $\varnothing \mathrm{b}$ i en lidt tilfældig orden, hvor der ifølge lederen selv ikke er tale om anvendelsen af en bevidst strategi eller organisering af arbejdet.

En anden leder udtaler, at "vi kører ikke 'andres pædagogik, vi kører vores egen. Jeg er ikke særlig stærk teoretisk men jeg mener, at jeg har fået tingene til at virke" (Z4301-422). Denne form for pædagogik er tydeligvis forankret i en mængde gode erfaringer, og der lægges stor vægt på, at medarbejderne er glade for deres arbejde, ellers skal de ikke være i institutionen. Der lægges i denne type institutioner vægt på, at praksis bygger videre på, hvad der plejer at fungere, og at personalet samarbejder om tilrettelæggelse og gennemf $\varnothing$ relse af pædagogiske aktiviteter. Det er sammenhold, fællesskab og samhørighed, der tæller, og fænomener som strategi og ledelse i forbindelse med det pædagogiske arbejde nævnes ikke som havende betydning. Der er forskellige udtryksformer for det at arbejde erfaringsbaseret med børns læring, og det der samler dagtilbud i denne kategori, der består af ca. 1/3 af alle dagtilbud, der indgår i unders $\varnothing$ gelsen, er som nævnt, at man arbejder i temaer, og ofte korte - ikke sammenhængende - forl $\varnothing b$, men mere spontane aktiviteter. Det fælles er, at man arbejder ud fra en praksisbaseret faglighed, dvs. baserer praksis på, hvad der plejer at fungere - mens den førnævnte type faglighed, som, er karakteriseret ved at være teoretisk og forskningsbaseret er nært forbundet med ledelse og organisering.. Omvendt viser disse begreber sig at være vigtige, som vi skal se i den sidste del af analysen, når interviewet drejer sig om, hvilke udfordringer man står med som leder, og hvilke faktorer der opfattes som hæmmende for at højne kvalitet i den pædagogiske praksis. Behovsbaseret pædagogisk praksis

"Alle børn skal behandles efter hvad de har brug for, og hverdagen har en aktivitet, det bliver dog aldrig som man har tænkt sig fordi vi er nødt til at tage højde for hvordan barnet har det den dag" (X-317).

Den tredje grundform for pædagogisk praksis, en behovsbaseret tilgang, identificeres gennem analysen af interview med ledere, der beskriver, at der ikke lægges planer eller opstilles mål på forhånd. Derimod tages udgangspunkt i barnets behov eller dets problemer, som de fremtræder den pågældende dag. En leder udtrykker, at det er "svært at overskue børnegruppen, de skal have en hånd hele tiden og det kan vi ikke give dem" (X-313). 
En anden leder siger: Det kan fx være at barnet ikke har fået morgenmad, ikke har været $i$ bad et par dage, så er vi nødt til at tage højde for, hvordan barnet har det og hvad barnet egentlig magter" (X-317).

Lederen fortæller videre, at "når mange på en gang har det svært bliver det ren brandslukning, da vi er nødt til at dykke ned i almindelig tryghed og omsorg og det er jo træls at man så ikke når det man gerne ville".

Men der er også eksempler på, at hverdagen planlægges ad hoc, "vi ser hvad der sker og hvad der er behov for", og adspurgt om begreber om læring, trivsel og inklusion svares det samme, "vi ser hvad der er behov for" (X-351).

Endelig viser det sig inden for denne kategori, at man arbejder med "dagligdags ting". Men adspurgt om, hvordan man mere konkret arbejder med de tre elementer, børns læring, trivsel og sociale inklusion, så er svarene mere tøvende. Fx adspurgt om inklusion, svarer lederen: "Ja, hvad gør vi? Vi prøver at være opmærksomme på de børn, som ikke er med i fællesskabet og prøver at få dem gelejdet ind, måske ved at hive fat i nogle af de her ressourcestærke børn, bruger de stærkere børn". Hvad gør vi ellers? Nu skal jeg lige tænke mig om, vi finder vi på lege" (Z-2 201 316). Når man spørger mere ind til lederens opfattelse af situationen, har vi identificeret svar, som tyder på, at man i dette dagtilbud ikke selv føler sig så godt fagligt klædt på til opgaven, som vi ser eksemplificeret i et lederinterview: "Vi har en masse ideer og visioner, men vi er ikke gået i gang endnu, Vi har nu kørt med en gammel ledelse og personalegruppe som har stået stille i mange år" (ibid.).

Noget tyder i de to førstnævnte eksempler på, at dagtilbud præget af mange ressourcesvage børn kan opfatte det som sværere at planlægge dage og læringsforløb, så organisering af det konkrete pædagogiske arbejde bliver fastlagt og struktureret. Men som vist i det tredje eksempel kan der også være tale om, at dagtilbuddets indre linjer, ledelse og personalemæssige ressourcer kan opleves som hindringer for at skabe en pædagogik, der på mere fokuseret måde sigter mod at fremme udsatte børns læring og trivsel gennem social inklusion.

Det, der karakteriserer denne sidste kategori, som også gælder for $1 / 3$ af alle deltagende dagtilbud, er, at dagen planlægges 'ad hoc', vi ser, hvad der sker, og hvad børnene lige den dag har behov for. Nogle dage når man, som en af lederne udtrykker det, ikke andet "end at passe børn" eller" brandslukning", når der er rigtig mange børn, der har det svært. Denne kategori ser ud til at hænge tæt sammen med det at være placeret i et område, der har stor forekomst af udsatte børn, så man måske ikke har overskud i hverdagen til at organisere og planlægge en mere 
teoretisk baseret pædagogisk praksis. Sammenholder vi analysen med tematikken om strategisk versus ikke-strategisk arbejde med at udvikle kvalitet i dagtilbud, som er præsenteret i foregående sektion, kan følgende træk beskrives for de tre grundformer, som omsættes i en model for læringsorienteret pædagogisk praksis:

Tabel 2. Sammenhæng mellem pædagogiske praksisser og læringstema

\begin{tabular}{|c|c|c|}
\hline Grundform & Strategisk & Ikke-strategisk \\
\hline $\begin{array}{l}\text { Teoribaseret pædagogisk } \\
\text { praksis }\end{array}$ & $\begin{array}{l}\text { Dominerende } \\
\text { Planlægning, målsæt- } \\
\text { ning og evaluering } \\
\text { (møder) } \\
\text { Organisering, struktu- } \\
\text { rering (fx gruppest } \varnothing \text { - } \\
\text { relser) } \\
\text { Ledelsesstyring af pro- } \\
\text { jektforl } \varnothing \text { b, planer (evt. } \\
\text { teknologier) }\end{array}$ & $\begin{array}{l}\text { Netværk internt og } \\
\text { eksternt } \\
\text { Vidensdeling i praksis } \\
\text { Interaktion og kom- } \\
\text { munikation }\end{array}$ \\
\hline $\begin{array}{l}\text { Erfarings- og behovs- } \\
\text { baseret pædagogisk } \\
\text { praksis }\end{array}$ & $\begin{array}{l}\text { Vi gør det, vi plejer, } \\
\text { men er s } \varnothing \text { gende i for- } \\
\text { hold til at skabe en } \\
\text { sammenhængende } \\
\text { kontekst }\end{array}$ & $\begin{array}{l}\text { Dominerende } \\
\text { Dagen tilrettelægges } \\
\text { ad hoc } \\
\text { Opgaven består i at } \\
\text { 'passe børn' og opfylde } \\
\text { basale behov } \\
\text { Praksis baseres på } \\
\text { børns parathed }\end{array}$ \\
\hline
\end{tabular}

Når vi ser på tværs af data og de deskriptive analyser af data i dette kapitel, så kan grundform 1, det at arbejde teoribaseret og læringsorienteret, kobles til den kategori, som tidligere er identificeret ved en mere strategisk måde at arbejde med viden og læring på. Grundform 2 og 3, det at arbejde erfaringsbaseret med læring og trivsel eller ikke arbejde eksplicit med læring, men derimod ud fra 'en 
behovsbaseret tilgang', kan helt overordnet begge kobles til en ikke-strategisk måde at arbejde med viden og udvikling på, på trods af at der også vil være mere strategiske afarter, selvom de ikke træder tydeligt frem i datamaterialet. Forholdet mellem de forskellige læringsformer og grundformer for pædagogisk praksis vil blive behandlet på et dybere analytisk niveau i senere publikationer i VIDAserien og vil også her blive vurderet i forhold til, hvad der skabes af muligheder for organisationernes evne til at lære at dele viden.

Som skitseret i tabel 2 er der en sammenhæng mellem det at arbejde hhv. teoribaseret og erfaringsbaseret med læring på en mere strategisk måde. I de unders $\emptyset$ gte dagtilbud, der arbejder teoribaseret, arbejdes projektorienteret med læring, med læreplaner fx ud fra årshjul, specificeret planlægning, opstilling af mål, procesmål og evalueringsmetoder. Dette planlægges via a) møder og bygger på, at medarbejderne er fagligt opdateret via b) kurser eller c) faglitteratur (fx inddrager lederen faglitteratur som fundament for arbejdet i praksis).

Som vi har set, kan disse arbejdsmetoder også kobles til den mere formelle læringsform, men også til læringskonteksten (se tabel 1), og naturligt overføres denne læringsform til arbejdet helt konkret med praksis. Endvidere er det karakteristisk for ledere, der arbejder teori baseret med en pædagogisk praksis, at der arbejdes systematisk med d) organisering af pædagogiske praksisser, e) ledelsesstyring (lederen har lagt en strategi sammen med medarbejderne, og man følger en fælles plan), og f) der arbejdes med evaluering i forskellige udformninger. I nogle institutioner er der identificeret eksempler på at arbejde med teknologier til at underst $\varnothing$ tte det pædagogiske arbejde med kommunikation mellem b $\varnothing$ rn og voksne.

VIDA-projektet lægger på til at de tre vidensformer kommer i spil. Dvs. at den teoretiske og forskningsbaserede viden og pædagogiske praksis som er i fokus på VIDA uddannelsen reflekteres sammen med den erfaringsbaserede viden og pædagogiske praksis, som deltagerne har oparbejdet gennem mange års erfaringer og bringer med sig ind i opgaven. Den behovsbaserede pædagogiske praksis baseres på hensyntagen til de børn og deres særlige behov, projektet drejer sig om. VIDA projektet vil først rigtig få succes hvis det lykkes at bruge disse tre videns og praksisformer kommer til at indgå i et dynamisk samspil med hinanden.

\section{FAKTORER AF BETYDNING OG FORVENTNINGER TIL VIDA}

I den følgende sektion analyserer vi informanternes overvejelser over spørgsmål om: Hvilke fremmende og hæmmende faktorer fremhæver lederne som udfor- 
dringer i arbejdet med udsatte børn? Hvad er ledernes opfattelse af og forventninger til, at VIDA kan gøre en forskel, og er det ifølge lederne muligt inden for givne rammer og vilkår at yde den optimale indsats for socialt udsatte børn? Analysen omhandler også overvejelser over egen formåen som ledere og personalets samlede faglige kapacitet i forhold til udfordringer i dagligdagen.

Den kvalitative analyse har gjort det muligt at komme tættere på ledernes opfattelser af faktorer og udfordringer, som kan hindre, at VIDA kan gøre forskel i netop deres dagtilbud. De fund, som er skitseret i det følgende, er samlet i bilag 3 og knytter sig de tre grundformer for pædagogiske praksis, der er identificeret i ovenstående analyser.

\section{Faktorer, der griber hindrende ind - udfordringer}

Der er i interviewene identificeret to modsatrettede måder at beskrive faktorer af hæmmende betydning for arbejdet med læring, trivsel og inklusion i dagtilbuddet på relateret til udsatte børn. Ved at spørge til, hvilke udfordringer lederen oplever, ser vi to hovedkategorier: Ydre forhold og indre forhold.

En række ydre forhold er identificeret som forhindring eller udfordringer i relation til at gøre en forskel for socialt udsatte børn. Her differentieres mellem lederens italesættelse af betydningen af ressourcer, nedskæringer, forandringer i kommunen og tid på den ene side til lederens italesættelse af betydningen af børnesammensætning og udsatte børns vilkår som fx det at vokse op i en familie, hvor "forældrene sidder på bænken til sent om aftenen" (Z-4101-417) på den anden side. Ifølge opgørelsen på samtlige interview finder vi gengangere af forhold, der nævnes inden for de tre grundformer som forhindringer.

I alle tre kategorier over grundformer for pædagogisk arbejde finder vi, at der nævnes: Ressourcer, normeringer, besparelser, pædagogers uddannelse og forholdet mellem uddannede og ikke uddannede pædagoger som dilemmaer, der er allestedsnærværende for alle, uanset om man arbejder teoribaseret, erfaringsbaseret eller behovsbaseret, og som kan vanskeliggøre, at pædagogikken kan udfoldes efter intentionen. Også de fysiske rammer nævnes som forhold, der kan gribe hindrende ind. Dette forhold italesættes forskelligt. For nogle institutioner drejer det sig om æstetik, for andre drejer det sig om plads, og atter andre nævner, at de 'fysiske rammer' bare ikke er gode nok.

I alle tre kategorier nævnes, at børnesammensætningen kan vanskeliggøre en optimering af indsatsen, der kan være generelt mange udsatte børn, som har det 
svært, og der kan være mange tosprogede børn og ikke råd til tolke. Endelig kan der være børn, som er så belastede, at de skal starte dagen med fx morgenmad, at blive vasket og få rent $t \varnothing j$ - hvilket ikke harmonerer med en målrettet strategi for pædagogikken.

Som nogle tendenser, der differentierer mellem de tre kategorier, er forhold som 'tværfagligt samarbejde, der er svært', som nævnes i den gruppe, der er kategoriseret ved at arbejde teoribaseret, mens forhold som 'krav oppefra' nævnes i den gruppe, der arbejder erfaringsbaseret. I gruppen, der arbejder behovsbaseret, nævnes forhold som, at der er mange børn, der har det svært. Disse forskelle kan skyldes, at man ser forskelligt på udfordringer afhængigt af den tilgang, man arbejder ud fra, men det kan også være tilfældigheder eller knyttet til kommuner eller enkeltdagtilbud. Tendenserne kan udforskes yderligere eller lægge op til, at man i videreudvikling af VIDA-indsatsen ser nærmere på disse forhold og unders $\emptyset$ ger mere indgående, i hvor vid udstrækning disse hindrer, at indsatsen kan implementeres efter hensigten.

For det andet er identificeret indre forhold som hindringer for arbejdet med udsatte børn og for de forandringer i dagtilbuddet, som anses for nødvendige.

En gruppe informanter fremhæver, at det største problem er faglighed, både egen formåen som leder, personalets kompetencer og det forhold, at der er mange uddannede med i personalegruppen, som ikke er rustet til at arbejde målrettet og videns- og læringsbaseret. En anden gruppe informanter beskriver rutiner, og det 'vi altid har gjort' som en hindring - ikke mindst fordi personalegruppen ikke sådan lader sig rykke, 'vi er for mange gråhårede damer' (Æ-2010573), som en af lederne udtrykker det, så det vil tage mange år at forandre praksis.

Nogle af de indre forhold, som er identificeret som forhindringer for at arbejde med fornyelse af indsatser for socialt udsatte børn, drejer sig også om eksempler på direkte modstand mod et system, der stiller st $\varnothing$ rre og st $\varnothing$ rre krav om at arbejde med planer, efter skemaer og mere struktureret, end man i dagtilbuddet $\varnothing$ nsker, samt politiske trends, som man ikke kan identificere sig med.

Her ses st $\varnothing$ rre forskelle på italesættelsen af indre udfordringer, som kan tilskrives den tilgang, man arbejder ud fra. Inden for den teoribaserede tilgang finder vi overvejelser over, at hindringer kan knyttes til personalet, dets moral, etik, at få personalet til at turde blive set, sætte trygheden på spil, men også at selve personalets 'habitus', dvs. egen personlige baggrund i en Bordieu'sk forstand, kan 
opfattes som en hindring for praksisudvikling. Lederen, der gerne ser en struktureret pædagogik og en klar organisering af hverdagen, ser i højere grad end i de andre grundformer sådanne personalemæssige forhold som udfordringer. Lederen i denne gruppe udtrykker også omsorg over for personalet - de er for ambitiøse og skal tilpasse ambitioner med muligheder.

Anderledes forhold fremhæves i den gruppe, der arbejder erfaringsbaseret. Her er der et tydeligt behov for at arbejde mere organiseret, men organiseringen af den pædagogiske praksis opleves som svær, og arbejdspladskulturen nævnes som svær at ændre. Endvidere er der vaner, der ikke lader sig forandre, og personalet skal lære at handle frem for at forklare sig ud af problematikkerne. I den tredje gruppe, den der arbejder behovsorienteret og ikke så organiseret, vises også tegn på, at det netop er det at arbejde med organisering, refleksion, faglighed, samt at det er svært at tænke nyt, opleves som de store udfordringer på det indre plan.

I alle tre kategorier nævnes især forhold, som har at gøre med faglighed som udfordringer for at optimere indsatsen. Det er tilsyneladende et fælles behov for alle deltagende dagtilbud for personalemæssig kompetenceudvikling fagligt og personligt.

\section{Forventninger om, at VIDA kan 'gøre en forskel'}

Lederne er spurgt: 'Hvilke forventninger har du til, at VIDA-projektet vil gøre en forskel for udsatte børn nu og på længere sigt?’

I baseline-analysen fandt vi overordnet en positiv motivation for VIDA projektet, men vi fandt også, at der blandt deltagerne kunne identificeres tre gennemgående mønstre: Dårlig motivation, mellemgrad af motivation og god motivation (Jensen et al., 2011b: 43-45). Disse mønstre for motivation er helt tydeligt sammenhængende med deltagernes opfattelser af udfordringer og faktorer, der opleves at kunne gribe hindrende ind i arbejdet.

Fx er dårlig motivation set fra baseline-analysen knyttet til, at børnegrundlaget ikke passer til VIDA-projektets definitioner på udsatte børn, så der opleves i nogle institutioner et relevansproblem. Vi ser også, at en mellemgrad af motivation eksempelvis er knyttet til det, at det tidsmæssigt er et problem at deltage (dvs., at timingen i forhold til kommunens $\varnothing$ vrige projekter kunne være bedre), og at egne ambitioner om at gøre det rigtig godt ikke modsvares af $\varnothing$ gede ressourcer i form af tid til at sætte sig ind i projektet. Tid til den faglige fordybelse, som vi også så ekspliciteret i afsnit 4.2, er af stor betydning for mange af VIDA-dagtilbuddene. 
Endelig viser det sig, at god motivation er knyttet til en oplevelse af a) relevans, b) at være med til at gøre en positiv forskel ved at bidrage til forskning og c) at ny viden, vidensdeling, netværk og efteruddannelse hilses velkommen.

Analysen fra statusrapport 2 viser, at langt de fleste lederudsagn drejer sig om at have positive, og som nogle ledere udtrykker det, store forventninger til VIDA. Udsagnene fra analysen taler for sig selv, og samlet viser de, at for lederne med en positiv indstilling til VIDA, uanset om de arbejder ud fra den ene, den anden eller tredje tilgang til pædagogikken, har lederne en forventning til, at VIDA vil kunne gøre en forskel også på længere sigt. Flere nævner, at VIDA kan hjælpe til at 'blive en dygtigere leder', 'grave et spadestik dybere', at få debatten hævet op over praksis, sætte dialoger i gang, at vi gennem VIDA får nogle rigtig 'fede' begreber og allerede (sommer 2011) er blevet lidt mere bevidste.

De få ledere, der udtrykker en skepsis over for VIDA, fremhæver, at forandringer som følge af VIDA ikke 'er noget, der sker i morgen eller 'over night', og når man ikke er den store teoretiker og ikke $\varnothing$ nsker at 'bruge andres pædagogik', så siger lederen fx: "Vi får se".

Samlet set er der på interviewtidspunktet en god stemning omkring VIDA og en tro på, at det kan hjælpe med at højne fagligheden, hvilket stemmer godt overens med de forudsætninger og udtrykte behov, der er forbundet med at opleve hindringer for pædagogikken, som netop drejer sig om faglighed, uddannelse, efteruddannelse og det at være i dialog og få hjælp til begreber og refleksion. Det videre forl $\varnothing \mathrm{b}$ i VIDA-uddannelsen 2012 og analyser efterfølgende vil vise, om disse forventninger indfries, men overordnet er der grund til her midtvejs i projektet at tro, at interventionens uddannelsesstrategi (se kap. 2 og 3) er relevant for langt de fleste deltagere.

Sammenfattende viser denne anden del af analysen om eksisterende praksis i VIDA-dagtilbud, hvad angår pædagogisk arbejde med børns læring og trivsel gennem social inklusion, og specifikt rettet imod socialt udsatte børn, at der er en sammenhæng mellem tage udgangspunkt i et teoretisk begrebsligt fundament, beskrive hvordan det omsættes konkret i aktiviteter i praksis, og graden af målrettet, systematisk og refleksionsbaseret praksis. Endvidere finder vi en sammenhæng mellem det at arbejde strategisk og målrettet med de i afsnit 4.2 identificerede tematikker og graden af at være reflekterende over valg af pædagogisk praksis helt generelt. Vi har i analysen unders $\emptyset$ gt, om denne ekspliciterede strategiske tilgang også kan identificeres i arbejdet med socialt udsatte børn. 
Analysen viser, at en formel og strategisk ledelsesform er knyttet til det at arbejde målrettet og teoribaseret med praksis for udsatte børn. Dagtilbud, der har en strategi og konkrete organiseringsformer i arbejdet med udsatte børn, er ud fra ledernes egne udsagn præget af $h \varnothing j$ faglighed. Der er tillige en bevidst refleksion over, hvordan praksis tilrettelægges og organiseres - hvad målene er, og hvordan de evalueres. I sådanne dagtilbud struktureres den pædagogiske praksis med stor tydelighed, fx lægges der i alle disse dagtilbud vægt på betydning af gruppest $\varnothing \mathrm{r}-$ relser af børn og fordelingen mellem børn og voksne. Der lægges også vægt på faglighed i personalegruppen, og de tre læringsformer og tilhørende læringsmetoder, som er identificeret i afsnit 4.2, kan genfindes i ledernes beretninger om tilrettelæggelse af den pædagogiske praksis. Analysen viser videre, at det at arbejde henholdsvis erfaringsbaseret og behovsbaseret knytter sig til den læringsform, der er identificeret tidligere i kapitlet (som informel, og inden for denne kategori arbejdes med forskellige gradueringer af metoder).

Der ikke fundet afgфrende forskelle på faktorer på et ydre plan, der af lederne fremhæves som udfordringer, der kan gribe hindrende ind i det pædagogiske arbejde. Derimod ser vi på et indre plan forskelle på den måde, ledere, der arbejder ud fra en teoribaseret tilgang, og den måde, ledere, der arbejder ud fra erfaringsbaseret eller behovsbaseret tilgang, italesætter de udfordringer på, de oplever. Førstnævnte fremhæver pædagogers personlige habitus og adfærd som udfordringer, mens ledere fra sidstnævnte to kategorier fremhæver organiseringen, at det er svært at tænke nyt, og faglighed som 'en kamp' som vigtige udfordringer.

Vi har også fundet, at på tværs af pædagogiske praksisser er der overvejende positive forventninger til, hvad VIDA kan bibringe dagtilbuddene. Den mere nuancerede del af analysen vil kunne vise differentieringer med hensyn til sammenhænge mellem dagtilbuddets intentioner, oplevelse af udfordringer, og det man fremhæver, VIDA forventes at komme til at betyde. Denne indgående analyse er ikke medtaget her, men det vil være muligt at vende tilbage til data, når implementeringsprocesserne i VIDA-projektet skal belyses i de afsluttende effektanalyser, hvor man også vil kunne berøre betydningen af de forskellige dagtilbudstypers påvirkning på læringskapaciteten i de unders $\varnothing$ gte dagtilbud.

\subsection{OPSAMLING OG KONKLUSION}

Samlet set viser dataanalysen i forhold til ledernes beskrivelser af det konkrete arbejde med at inddrage viden og skabe læring, at de formelle læringsmetoder 
er de primært anvendte. Specielt anvendt er mødet i forskellig form efterfulgt af kursusaktivitet og læsning af faglig litteratur. Læringskonteksten fremhæves som en vigtig faktor for arbejdet med konkret inddragelse af ny viden og læring i dagtilbud. I forhold til at udvikle kvalitet i det pædagogiske arbejde ser vi primært tre tilbagevendende tematikker gøre sig gældende. Den ene tematik handler om den strategiske adfærd, den anden tematik handler om graden af sammensatheden i informanternes opfattelse af, hvordan de arbejdede med at skabe udvikling i deres dagtilbud, og endelig retter tredje tematik fokus mod lederens rolle som supervisor eller sparringspartner.

Vi har påvist tre former for tilgange til arbejdet med viden, faglighed og fornyelse, som man kan forvente vil få en betydning for den måde, dagtilbud arbejder med VIDA-programmet på i udgangspunktet. De tre former for tilgange er: ekspliciteret teoribaseret tilgang til opgaven, erfaringsbaseret tilgang til opgaven og behovsbaseret tilgang til opgaven. Hvordan de tre pædagogiske praksisser eller grundformer vil udvikle praksis og læringsstrategier gennem forl $\varnothing$ bet, vil blive studeret gennem opfølgende dataindsamlinger via surveys (2012) og afslutningsvis ( 2013) med alle ledere. Også bes $\emptyset$ g i udvalgte dagtilbud og afsluttende fokusgruppeinterview med samtlige ledere vil kunne give informationer om de organisatoriske læringsprocesser i VIDA-dagtilbud.

De fund, der er gjort, om relationer mellem de forskellige pædagogiske praksisser og nogle af de tematikker, som kom til udtryk i analysen af, hvordan lederne inddrager ny viden i dagtilbud, vil være helt centrale at gå videre med i fremtidige analyser af implementeringsstrategier af VIDA programmet. Der synes således helt overordnet at være forskellige grundtyper til stede blandt de udvalgte dagtilbud i VIDA-projektet. Nogle synes at arbejde meget målrettet og strategisk med inddragelse af viden såvel som med de pædagogiske praksisser, mens vi ser andre typer, som arbejder mere intuitivt og erfaringsbaseret Vi vil understrege, at vaner og rutiner er grundlæggende for alle organisationer - naturligvis også for de unders $\varnothing$ gte dagtilbud af mere strategisk natur. Det, vi sætter analytisk fokus på her, er forskellene mellem de unders $\emptyset$ gte dagtilbud i måden, hvorpå de arbejder med at udvikle og udfordre vaner og rutiner. Det er her, vi ser, at nogle er meget eksplicitte og strategiske i forhold til at skabe retning på udviklingen, mens andre er mere implicitte og erfaringsbaserede i forhold til retningen og styringen af den pædagogiske praksis og inddragelse af viden. Det bliver i denne sammenhæng interessant at følge de forskellige dagtilbud i forhold til at se udviklingen på baggrund af VIDA-implementering af former for inddragelse af viden og ændring af pædagogiske praksisser, og se i hvor høj grad de forskellige fremmende og hæmmende faktorer påvirker implementering. 
Dagtilbud, der i udgangspunktet er karakteriseret ved en formel og strategisk læringsform, som defineret ovenfor, er som vist i analysen indstillet på at tage VIDA til sig, bygge videre på det grundlag, der allerede ligger i læringskulturen, der er defineret som 'åben' over for nye input. Man kan karakterisere disse typer af institutioner som nysgerrige i forhold til deres syn på læring. Samtidig er man sig bevidst, at der er en række udfordringer, men bevidstheden rækker også til at have $\varnothing$ je for, hvilke strategier der skal til for at navigere i forhold til udfordringer og håndtere dem. Omvendt ser vi hos dagtilbud, for hvem VIDA enten forekommer for udfordrende eller måske mindre relevant, da gruppen af udsatte børn måske i mindre grad passer med VIDAs definition, at opgaven mødes mere skeptisk eller tøvende. Sådanne forskelle kan få betydning for implementering af VIDA.

Med de forbehold, der må tages for det oparbejdede datamateriales repræsentativitet i forhold til dagtilbud generelt, idet de 80 ledere repræsenterer VIDA-dagtilbud, viser analysen, at de forskelle, der er sporet i den samlede beskrivelse af arbejdskultur, læring og konkret praksis, relaterer sig til den måde, dagtilbuddet møder udfordringer og vilkår på, og at dette generelt vil få betydning for dagtilbuddets potentialer for læring i den samlede organisation. Analysen må forventes at give gyldig viden om sammenhænge mellem potentialer for læring og den måde, dagtilbuddet mere specifikt forholder sig til og håndterer de opgaver på, som VIDA-projektet lægger op til, samt implementering. Det kvalitative datagrundlag, der ligger til grund for denne analyse, gør det som nævnt ikke muligt at generalisere denne påstand om en typologi, kun at fremsætte en hypotese. Området kalder således på yderligere udforskning gennem processen fra VIDAprojektets start til dets implementering.

Sammenfattende peger analysen, på at det krav der ligger i VIDA perspektivet om organisatorisk læring, på unders $\emptyset$ gelsestidspunktet var en stor udfordring at forpligte sig på og konkret organisere måder, hvorpå det samlede dagtilbud kan arbejde med ny forskningsbaseret viden og omsætte denne sammen med egne erfaringer i innovative strategier i praksis. Midtvejsanalysen vidner om at dette for mange er nytænkende og krævende - men også at interessen og motivationen er til stede. Opfølgende casestudier (gennemf $\varnothing$ rt i udvalgte institutioner, marts 2012) ved feltstudier og interview med leder og medarbejdergrupper nuancerer imidlertid billedet, idet det her (ca. $3 / 4$ år efter interviewene blev gennemf $\varnothing \mathrm{rt}$ ) bidrager til indsigt, i at dagtilbuddene arbejder målrettet og systematisk med at få VIDAs perspektiverne og hele ideen om organisatorisk læring implementeret. Diversitet i dagtilbuddene indebærer, at processen finder sted med forskelligt 
tempo og udbytte, men processen er sat i gang og medarbejdere søges involveret i det samlede dagtilbud de steder, vi besøgte. 
VIDENSBASERET INDSATS OVER FOR UDSATTE BøRN I DAGTILBUD 


\title{
KAPITEL 5
}

\section{FORAELDREINDDRAGELSE I VIDA}

\author{
Peter Berliner \& Dorte Kousholt
}

\subsection{INDLEDNING}

I VIDA-projektet indgår forældreinddragelse og -samarbejde som en betydningsfuld del. I unders $\varnothing$ gelsen af VIDA-projektet er der foretaget interview med ledere og medarbejdere i de deltagende institutioner. I dette kapitel behandles de dele af interviewene, der omhandler, hvordan lederne forstår betydningen af forældreinddragelse for styrkelsen af livsmuligheder for udsatte børn, og hvilke metoder de anser for afgørende i dette arbejde. Desuden er lederne spurgt om deres syn på udviklingsmuligheder i forhold til forældreinvolvering i dagtilbuddet.

Formålet med interviewene har været at få konkrete beskrivelser af den eksisterende praksis i forhold forældreinvolvering. Dette kapitel viser gennemgående træk ved den måde, som forældresamarbejde opfattes og tilrettelægges på - samt beskriver de dilemmaer og udfordringer, der er for dagtilbuddene i forbindelse med forældresamarbejdet. I interviewene fortælles det, at det, der fra institutionernes side lægges vægt på i forældresamarbejdet, er (1) at opbygge en åben, gensidig, direkte og anerkendende dialog, fortrinsvis bygget op gennem den daglige kontakt og samtale; (2) hurtig indsats ved observerede udfordringer i forhold til trivslen for et enkelt barn og/eller børnegruppen; (3) at der er en fortløbende information om, hvad der foregår i institutionen samt (4) en klar og åben forventningsafstemning mellem hjem og institution.

Konkret er forældresamarbejdet organiseret ved, at forældresamtaler, forældremøder og fælles arrangementer planlægges og gennemf $\varnothing$ res for at give informationer, skabe rum for den gode dialog og for at styrke forældre-til-forældre-samarbejdet. Der er mulighed for at få samtaler med pædagogerne, hvis det $\varnothing$ nskes - dog er der her stor forskel på, hvornår og hvordan man kan få en sådan samtale.

Forældresamarbejdet omkring udsatte børn består i at have en god dialog, have hyppigere forældrem $\varnothing$ der og have tværfaglige netværksm $\varnothing$ der. Endvidere består det $\mathrm{i}$ at lave arbejdsdage og andre praktiske arrangementer, hvor de udsatte 
børns forældre opfordres til at deltage. Dette er dog stadig snarere et $\varnothing$ nske end gennemf $\varnothing r t$ mange steder. Der er også i nogle institutioner særlige aktiviteter for udsatte familier såsom grupper for mødre og par samt aktiviteter, hvor forældre kan deltage i aktiviteter og samspil med deres barn i institutionen. Disse særlige tiltag findes dog kun i meget få institutioner.

Det beskrives videre i interviewene, at der er bestemte udfordringer mht. at få forældresamarbejdet til at fungere optimalt. Disse er eksterne og interne. De eksterne udfordringer omfatter: (1) forældrenes travlhed og (2) forældrenes opprioriteringer af eget barn, som ses som en modsætning til fællesskabet. De interne udfordringer omfatter: (1) at nogle medarbejdere har svært ved at udf $\varnothing$ re en anerkendende holdning - både i ord og i praksis, og (2) at man som medarbejdergruppe kan komme til at bygge videre på hinandens negative opfattelser af bestemte forældre - og derved opbygge en ekskluderende diskurs og praksis.

Mht. mulighederne for at styrke udsatte børns trivsel igennem et godt forældresamarbejde så vi i interviewene, at man gerne vil udbygge ved at (1) opbygge et generelt forældresamarbejde, der er inkluderende over for de udsatte børns forældre; (2) skabe muligheder for de udsatte børns forældre for at indgå i aktiviteter, hvor de kan deltage ligeværdigt, og hvor de har kompetencer til at deltage, fx i praktiske aktiviteter; (3) få muligheder for mere direkte, praktisk vejledning af forældre til udsatte børn enten i institutionen eller i hjemmet; og (4) bevare, styrke og videreudvikle medarbejdernes kapacitet til at varetage den anerkendende og løsningsorienterede dialog, der ses som det mest betydningsfulde i samarbejdet med forældre til udsatte børn.

Dette kapitel baserer sig på analyser af de kvalitative interview med lederne af de deltagende dagtilbud (undtaget kontrolgruppen - jf. redegørelse for metoden i kap. 4 og 6 i denne statusrapport). Formålet med interviewene har været at få konkrete beskrivelser af den eksisterende praksis i forhold til forældreinvolvering. Ambitionen med dette kapitel er at vise gennemgående træk ved den måde, forældresamarbejde opfattes og tilrettelægges på, samt beskrive de dilemmaer og udfordringer, der er for dagtilbuddene i forbindelse med forældresamarbejdet.

En mulig bias i denne unders $\varnothing$ gelsesmetode kunne være, at lederne og medarbejderne beskriver, hvordan de фnsker, at situationen skulle være, snarere end at give en beskrivelse af den faktiske situation. Dette kunne skyldes et $\varnothing$ nske om at fremme de træk, man beskriver, i forældresamarbejdet. Der er dog ingen argumenter for, at dette skulle gøre sig gældende her, idet lederne og medarbejderne dels er anonymiserede i gengivelsen af resultaterne - og var informerede 
om dette fra begyndelsen af unders $\varnothing$ gelsen. Endvidere er det ingen klar fordel for dem at beskrive en idealsituation snarere end den faktiske. Også selve spørgsmålene i forbindelse med at beskrive situationen, som den er nu, og planer for videre bevarelse - og udbygning - af de styrkende og resultatgivende aktiviteter i forældresamarbejdet, gør, at der skelnes klart mellem den faktiske situation og $\emptyset$ nskerne om bevarelse og udbygning af samarbejdet i fremtiden.

I selve designet kommer man til at se på den generelle situation. Man kunne derfor spørge, hvorledes dette er relevant for VIDA-projektet. Svaret på det spørgsmål er, at man i VIDA-Basis +-institutionerne vil kunne fokusere sine særlige indsatser for at styrke forældresamarbejdet og kan bygge videre på de særligt gode erfaringer der er med forældresamarbejde og med forældrene i de særligt udsatte familier. På denne måde er disse erfaringer og ideer betydningsfulde for forældresamarbejdets udvikling i VIDA-Basis +-forældreprogrammet.

I vores gennemgang af resultater vil vi se på gennemgående træk i materialet, dvs. de tematiseringer, der oftest optræder i interviewene. Endvidere vil vi beskrive særlige positioner, hvor disse adskiller sig væsentligt fra de $\varnothing$ vrige interview.

Vi opdeler kapitlet ud fra de fem spørgsmål, der blev anvendt i interviewene om forældredelen: (1) Hvad lægger I vægt på i forhold til forældresamarbejde i jeres dagtilbud? (2) Hvordan tilrettelægger I samarbejdet med forældre i jeres dagtilbud? (3) Tilrettelægger I samarbejdet med udsatte familier (forældre) på samme måde? (4) Hvilke udfordringer ser du i forældresamarbejdet? (5) Ser du nogen muligheder i forældreinddragelse i forhold til arbejdet med udsatte børn?

\section{Hvad lægges der vægt på i forhold til forældresamarbejde i dagtilbud?}

Et gennemgående træk i svaret på, hvad der lægges vægt på i forhold til forældresamarbejdet, er, at det er inddragelse af forældrene igennem en åben og direkte dialog. Det understreges ofte, at dette sker i den daglige kontakt, og at det er igennem denne daglige kontakt, at man søger at opbygge gensidig tillid. At forældrene skal mødes på måder, der skaber tillid, er ligeledes et gennemgående træk. Endvidere søger man at skabe klarhed omkring forventninger, således at disse er åbne og direkte formulerede. Det understreges i mange af svarene, at dette skal ske på måder, der er anerkendende, og som ser forældrene som ressourcer og med et stort kendskab til deres børn. Det formuleres ofte, at forældrene ser børnene i en anden sammenhæng, end man gør i institutionen, og derfor har en anden viden om børnene, end det er muligt at få i institutionssammenhængen. Men der er omvendt også sider af barnets liv, som forældrene ikke ser, fordi det 
foregår i institutionen. Derfor er det betydningsfulde i forældresamarbejdet, som en leder udtrykker det:

"Dialog. At vi er enige om, hvad det egentlig er, der foregår og at der altid er plads til at stille spørgsmål. Tid til... prøve at tage os tid til at give dem lidt informationer hver dag om, hvordan dagen har været og hvordan deres børn trives. Det gør vi jo løbende."

Det nævnes i langt de fleste af interviewene, at dialogen med forældrene bør tages på en anerkendende måde, og at dette kan ske ved at spørge til gode situationer med barnet i hjemmet samt ved at fortælle de gode historier om barnet i institutionen. Derved opbygges der tillid gennem fokus på de gode oplevelser, fortælles der. Også ved netværksmøder er det en klar værdi for mange, at forældrene deltager sammen med de professionelle i disse møder, og at fokus på møderne er løsningsorienteret og ikke diagnosticerende.

Endvidere ser alle det som befordrende for forældresamarbejdet, at der informeres godt og grundigt om hvad der lægges vægt på i institutionen, hvilke aktiviteter der foregår, og hvad der forventes af børn og forældre. Den gode dialog omfatter også informationer den anden vej, nemlig om forældrenes forventninger til institutionen samt deres observationer af barnet i hjemmet.

Det er ligeledes en værdi for institutionerne, at man er i stand til at handle hurtigt, hvis der observeres en bekymrende adfærd hos et barn eller i gruppen af børn - eller i gruppen af forældre. Dette er vigtigt, da man har erfaringer med at finde løsninger på de fleste udfordringer, hvis man er i stand til at handle hurtigt, direkte og i et tillidsfuldt samarbejde med forældrene omkring indsatsen. En leder udtaler i den forbindelse:

"Vi er meget bevidst ikke-berøringsangste, vi fortæller, hvad der bekymrer os men prøver virkelig altid at tænke: Er det mine egne normer jeg vil lægge ned over den her familie eller er jeg bekymret? Og drøfter det med mig eller en kollega. Men hvis man kommer frem til: Jeg er bekymret, så snakker man med forældrene."

Det er ligeledes vigtigt for mange, at man taler et direkte og klart sprog. Dette beskrives i nogle tilfælde som ærlighed, og det kan, som vi vil se nedenfor (under Udfordringer i forældresamarbejdet), nogle gange opleves som svært. Det svære kan bestå i, dels at ikke alle i personalet er vant til at tage samtaler om vanskelige emner på denne måde, og dels i at nogle forældre trækker sig fra dialogen. Denne vanskelighed s $\varnothing$ ges im $\varnothing$ degået med den anerkendende tilgang, der opbyg- 
ger gensidig tillid. Det understreges - som i citatet nedenfor - af flere, at forældre som oftest er meget åbne overfor konkret vejledning, hvis den gives på den rigtige måde - dvs. i en åben, gensidigt tillidsfuld og anerkendende dialog:

"Det kan for eksempel være, hvis der nu er et eller andet med et af børnene, hvor der er nogen ting, der er svære. Og der er et reaktionsmønster der er aggressivitet eller.. vi skal jo ligesom at pejle os frem til, hvad er nu det for noget. Så går vi jo ind $i$ en dialog med forældrene. Hvad kan det være? Er det rent fysisk, eller er der et eller andet han er ked af. Og det kan jo være, at der lige pludselig er fem naboer, der er ramt af sorg og man skal tænke på, at barnet mærker det. Så det kan være mange ting. Men der går vi jo ind. Hver dag der skal vi jo se, hvordan børnene har det. Og hvis... Vi skal jo lære dem så hurtigt at kende, så vi ved når de er kede af det, når de er glade og hvor vi kan være med til at styrke en god udvikling for dem. Der ser du jo så... pludselig så er der et eller andet med kroppen eller der er nogle ting, som bliver svære, jamen så skal vi jo finde ud af-hvad er så det? Vores rolle bliver klart, jamen altså, også når der sker noget $i$ løbet af dagen, vi ringer for at gøre forældrene opmærksomme på det, og siger sådan og sådan, vores vurdering er, men hvad siger I? Og der skal være tryghed hele vejen igennem. Tryghed og tillid, men det er lige så meget dét at sige nogle ting meget ærligt."

Det er for mange en værdi i organiseringen af forældresamarbejdet, at rygter stoppes hurtigt. Disse rygter kan have form af snak mellem pædagogerne omkring bestemte forældre (og børn) på måder, der stempler disse forældre negativt. Man kan ligefrem forenes i en sådan selvbekræftende og selvforstærkende dialog, fortælles det, hvilket gør den svær at bryde, med mindre det sker med det samme. Nogle steder har man indført regler for at bryde rygtetendensen i form af en procedure for, hvordan bekymringer skal bringes frem i institutionen. Der er der hos nogle den klare opfattelse, at man ikke kan formulere problemet rigtigt, før man har forældrene med i refleksionen. De skal derfor inddrages med det samme, når en bekymring er opstået blandt personalet. En anden form for rygter kan opstå blandt forældrene, der nogle gange kan udpege bestemte børn som problembærere og bidrage meget aktivt til eksklusionen af disse børn - igennem indbyrdes samtaler og gennem henvendelser til institutionen. Det ses her som vigtigt at stoppe dette gennem en åben dialog, hvor alle kan deltage - også de udpegede problembærende familier. Denne dialog formidles gennem institutionen, og vi ser, at målet er at stoppe rygter og udpegninger, før de spreder sig til børnene og bliver en social læringsproces hos dem om, hvordan det sociale liv kan blive præget af eksklusion. 
Værdien omkring anerkendelse viser sig ved, at man i mange institutioner arrangerer forældreaktiviteter, hvor det er muligt for alle familier at bidrage med noget, som de kan og er gode til, fx praktiske aktiviteter såsom madlavning eller reparationer for de mere praktiske - men også dialoger og refleksioner for de mere verbalt orienterede. Det er dog stadig en udviklingsmulighed for mange steder at fremme denne diversitet i forældreinddragelsen.

For mange institutioner er det en værdi, at man har en høj grad af professionalisme, og at man er i stand til at formidle dette til forældrene - således at de ved, at det, man foretager sig i institutionen, er baseret på viden og på fortløbende observationer af børnene, både som gruppe og som individer.

Det omtales ligeledes af nogle institutioner som værdifuldt i forældresamarbejdet, at man er i stand til at skabe et socialt netværk mellem forældrene indbyrdes. Dette nævnes som et generelt gode, men også som specielt godt i forbindelse med inklusionen af forældre til udsatte børn i forældregruppen. Man nævner her, at disse forældre ofte beskrives som marginaliserede og selv er udsatte. Det fortælles fra flere institutioners side, hvor vigtigt det er, at man som institution går ind i at fremme inklusionen af disse forældre i forældregruppen som helhed.

Vi ser således nogle klare temaer træde frem i og på tværs af interviewene:

Åbenhed ses som en værdi i - og især knyttet til - den daglige kontakt, herunder (1) at have en kontinuerlig kommunikation med forældrene ved aflevering og afhentning, (2) at kontakte forældrene, så snart noget "anderledes" ved barnet observeres, noget der bekymrer personalet, (3) at være lyttende til forældrene, at møde dem dér, hvor de er, at anerkende forældrene, fx se deres særlige ressourcer, men også (4) at sige tingene lige ud.

Tryghed ses som knyttet til gensidig tillid. Det understeges af nogle, at hvis forældrene er trygge ved institutionen, så er børnene det også. Det er vigtigt, at forældrene er trygge og tillidsfulde, så de dels fortæller om deres bekymringer (og glæder) og dels er åbne for at lytte til institutionens fortællinger om deres børn, også når der er tale om bekymringer og $\emptyset$ nsker om at foretage st $\varnothing$ ttende indsats enten for et enkelt barn eller for hele børnegruppen.

Dialog er et grundbegreb for forældresamarbejdet og dermed for at opbygge åbenhed og tryghed. Dialogen ses som præventiv og som problemløsende - og beskrives som kendetegnet ved anerkendelse, respekt og kontinuitet, men også 
som - nødvendigvis - direkte og klar. Sammenhængen mellem dialog, åbenhed og tryghed beskrives i en institution således:

"Det, der er rigtig vigtigt, det er at have en base af daglig dialog, altså at man ikke kun taler sammen til de formelle samtaler, men at forældre... Det vigtigste for forældre, det er, mener jeg, er tryghed. Det er nøgleordet. Hvis de er trygge ved, at deres børn har det godt, og hvad det så betyder, det kan man sige en masse om, så er der en god base for at komme videre, så de skal hver eneste dag mødes af professionelle og blive bekræftet $i$, at deres barn er blevet set og hørt. De skal have en historie med hjem."

I en anden institution beskrives den på denne måde:

"Den daglige dialog, det er utrolig vigtigt. Også at få fortalt den gode historie, det er utroligt vigtigt. alle børn har jo noget godt at byde på, og det skal man ikke glemme, At det kun er problemerne, man præsenterer forældrene for, så kommer man ingen vegne, og så får man ikke skabt nogen tillid, tværtimod så render de deres vej."

I en tredje institution blev den beskrevet således:

"Det handler om at forældre skal tænke: Det her er min institution, det er vores institution. Og der tror jeg, hvis forældre oplever, at det er vores institutioner og pædagogerne er her for vores barn - ikke fordi de skal have et arbejde, de kan få penge for, men de oplever at der er en form for ægte varme, kærlighed og omsorg i forhold til dem og deres barn, så kan man sige hvad som helst og nå næsten hvor som helst med de har forældre. For så er der ikke noget skjult i det."

Den åbne dialog knyttes til gensidig forventningsafstemning og hurtig indsats i det følgende citat fra en af lederne:

"Vi lægger vægt på stor åbenhed og stor inddragelse, fordi er der noget, personalet undrer sig over i forhold til et barn, vil jeg have, de med det samme siger det til forældrene. Jeg kan slet ikke klare det her med, at man går og snakker internt på stuerne og går og bekræfter hinanden $i$, at det her er mærkeligt eller at forældrene er lidt mærkelige. Jeg vil have en åben dialog med forældrene. ... Få dem inddraget omkring, der er noget, som vi som professionelle ser, er anderledes end de andre børn. Hvad kan vi gøre? Kan de gøre noget hjemme? Kan vi gøre noget hos os? Så den åbenhed er utrolig vigtig. Og så prøver vi at være - man kan sige-opdragende 
over for forældrene. Vi får meldt vores forventninger ud fra starten, hvad de kan forvente af os og hvad vi vil have af dem, for jeg vil ikke have, personalet render og leder efter hjemmesko og vanter, det må de selv klare."

Dialogen ses, som vist, som noget helt centralt i det, man lægger vægt på i forældresamarbejdet. Der lægges meget vægt på det mere uformelle i den daglige kontakt, da dette beskrives som en særlig styrke i forældresamarbejdet. Det er interessant at se, at der gives en række konkrete anvisninger på, hvordan denne uformelle, daglige dialog kan opbygges og styrkes - og hvordan den kan bruges både i det generelle forældresamarbejde og i samarbejdet med udsatte børns forældre.

Opsummerende ser vi, at der lægges vægt på (1) at opbygge en åben, gensidig, direkte og anerkendende dialog, fortrinsvis bygget op gennem den daglige kontakt og samtale; (2) hurtig indsats ved observerende udfordringer i trivslen for et enkelt barn og/eller i børnegruppen; (3) at der er en fortløbende information omkring, hvad der foregår i institutionen samt (4) en klar og åben forventningsafstemning mellem hjem og institution.

\subsection{TILRETTEL/EGGELSE AF FORÆELDREINDDRAGELSE I DAGTILBUDDET}

I Statusrapport 2 (Jensen et al., 2011b, kap. 3) beskrev vi de former for forældresamarbejde, der finder sted, samt hyppigheden af disse. Dette skete på baggrund af en sp $\varnothing$ rgeskemaunders $\varnothing$ gelse. Her vil vi ud fra de kvalitative interview beskrive, hvordan de aspekter af forældresamarbejdet, der trækkes frem som særligt betydningsfulde, konkret tilrettelægges. Dialog er den aktivitet i forældresamarbejdet, der nævnes oftest i interviewene. Den tilrettelægges i form af det daglige møde, i form af mere formelle forældresamtaler (der i nogle kommuner kaldes forældrekonsultationer) samt som forældrem $\varnothing$ der. Der omtales endvidere foredragsaftner og arbejdsdage, der dels har til formål at opbygge fælles forståelser og dels at skabe en sammenhængende forældregruppe.

En leder reflekterer over betydningen af denne dialog og siger, at åbenhed og ærlighed i dialogen er langt vigtigere end fællesspisninger og foredragsaftner. En anden siger, at den daglige kontakt er den aktivitet, der opbygger et grundlag for de mere formelle samtaler. En tredje siger, at udvekslingen af information især foregår i den daglige samtale - både information fra institutionens side og information fra hjemmet til institutionen. 
Det nævnes ligeledes af flere, at fester og arbejdsaftner er gode til at skabe den gode dialog. Det siges, at det er pga. samværet, at forældrene kommer. Nogle nævner, at der kan laves forældrearrangementer, uden at institutionens personale behфver at være med hver gang, men det nævnes i én institution, at man ikke støtter sådanne arrangementer, da man har erfaring for, at de kan skabe vanskeligheder for marginaliserede forældre, der let kan blive - eller blot opleve sig - som ekskluderede ved sådanne arrangementer. Også flere andre institutioner fortæller, at de ser det som en del af deres opgaver i forbindelse med forældresamarbejdet at bidrage til, at forældrene til de udsatte børn faktisk indgår i kommunikation og samspil med de $\varnothing$ vrige forældre ved fælles arrangementer.

Nogle institutioner beskriver, at de har et udvidet forældresamarbejde, der også omfatter hjemmebes $\varnothing$ g, hvor der vejledes i konkrete aktiviteter og fremgangsmåder med henblik på at skabe trivsel og god udvikling for barnet. Det beskrives ligeledes, hvordan denne form for vejledning kan finde sted i institutionen, hvor forældrene kan vejledes direkte i interaktionen med deres barn. Endelig omtales grupper for enlige og for udsatte mødre. Disse former for forældresamarbejde vil blive omtalt nærmere nedenfor i forbindelse med de indsatser, der gøres for udsatte børns familier. Der vil vi også beskrive netværksm $\varnothing$ der med professionelle og med deltagelse af forældrene.

En vigtig aktivitet i forældresamarbejdet er at give information. Det beskrives, hvordan denne information kan gives via opslag i institutionen, gennem en hjemmeside og gennem e-mail. Nogle udtrykker en vis skepsis over for hjemmesider, idet det er meget tidskrævende at vedligeholde dem med information dag for dag. Andre nævner e-mail som en hurtig måde at kommunikere med enkelte forældre på. Det understreges, at informationen skal gives på en måde, der når ud til alle på en effektiv måde - men det nævnes også, at dette er meget svært. Mht. til særligt udsatte familier omtales det af flere, at den personlige kommunikation er nødvendig for at få informationerne igennem.

Det nævnes i interviewene, at forældrene henvender sig meget mere nu omkring livet derhjemme - omkring konkrete emner eller omkring kriser - til medarbejderne, end de gjorde tidligere. Dette åbner for nye muligheder og udfordringer.

Nogle steder er man meget åben over for at tage samtaler med forældre, der $\varnothing$ nsker at få råd til at løse akutte problemer i deres liv. Dette vil især være omkring børnene, men enkelte steder er man åben over for samtaler også om andre emner, fx skilsmisse (også de aspekter, der ikke angår barnet direkte). Det er vigtigt, at disse samtaler kan tages hurtigt - også selvom det betyder, at en af medarbej- 
derne går fra arbejdet med børnene i den tid, samtalen tager, som følgende citat viser:

"Og så sætter de sig lige en halv time og ser på, hvordan man kan komme ud af den her spiral. Der siger vi altså ikke: Du har en samtale om fire måneder. Altså så prøver vi at tage fat $i$ det her og nu - og selvom det nogle gange, kan man sige, nu mangler jeg altså nede på stuen, det var ikke lige planlagt."

Andre steder er man sig meget bevidste omkring, at tiden til forældresamtaler ikke må tages fra tiden sammen med børnene. Derfor skal samtaler aftales, og der kan således være nogen ventetid på at få en forældresamtale. Der er også steder, der understreger, at denne form for samtaler skal holdes ude af garderoben og stuerne, idet børnene ellers vil kunne blive påvirkede af dem. Dette kan både angå det barn, hvis forælder $\varnothing$ nsker at tale med en pædagog om vanskeligheder i sit liv, og det kan angå de andre børn, der måske ikke forstår, hvad der foregår, og kan bringe dele af samtalen videre samt eventuelt bruge den til at stille spørgsmål til det barn, hvis forælder $\varnothing$ nsker samtalen. Det formuleres af en leder som: "Men det sker som aftaler - ikke i garderoben eller på stuen, da det ikke skal forstyrre arbejdet med børnene eller høres af disse."

Forældresamtalerne er en konkret aktivitet, der nævnes hyppigt i forbindelse med forældresamarbejdet. Det sker både som fastlagte forældresamtaler ved barnets start i institutionen og derefter én gang om året - eller hvis der er særligt behov for det.

Endvidere nævnes arrangementer, hvor forældrene inviteres til at spise sammen stuevis, da de på denne måde kan møde hinanden. I nogle institutioner arbejder man meget aktivt på at bringe forældrene sammen i aktiviteter og udstrækker også disse til at omfatte legeaftaler. Det betyder, at man fra pædagogernes side aktivt går ind i at skabe kontakt mellem forældre med henblik på, at alle børn kommer med i at bes $\varnothing$ ge hinanden og lege sammen efter timerne i institutionen. Det omtales også, hvordan forældrene selv kan bruge institutionen som et omdrejningspunkt for gensidig social st $\varnothing t t e$ - der gives et eksempel med, at forældrene stillede en fryser op i institutionen og kom færdiglavede retter i den, som så kunne hentes af en familie, der var i en krise- og sorgproces.

Et sted fortalte man således om ideen i at styrke forældre-forældre-samarbejdet gennem institutionens indsats: 
"Plus, at vi også prøver at koble forældrene til hinanden, hvis der er nogen, der har nogen bestemte udfordringer i forhold til noget, og at vi ved, at der er andre, der har nogle af de samme problemer, så kunne vi godt finde på at sætte os sammen og spørge, om vi ikke skulle snakke om det sammen osv."

"For så kan man høre, at der er andre, som har prøvet noget, man kan blive inspireret af, og så bliver det lidt ufarligt - og nogle gange løser tingene sig faktisk af sig selv, når man sådan tager fat på det."

Opsummerende bliver forældresamtaler, forældremøder og fælles arrangementer planlagt og gennemført for at give informationer, skabe rum for den gode dialog og for at styrke forældre-til-forældre-samarbejdet. Der er mulighed for at få samtaler med pædagogerne, hvis det ønskes - dog er der her stor forskel på, hvornår og hvordan man kan få en sådan samtale.

\subsection{FOR/ELDREINDDRAGELSE OM ARBEJDET MED UDSATTE BØRN}

I en del institutioner består indsatsen i forældresamarbejdet med forældre til udsatte børn i at gøre mere af det, som man ellers gør i forældresamarbejdet i det hele taget, dvs. forældresamtaler og dialog. Nogle steder begrundes dette med, at der er så mange udsatte børn i institutionen. De fleste steder begrundes det med, at det er det, der virker bedst, idet den åbne og respektfulde dialog er den bedste metode mht. at st $\varnothing$ tte disse familier.

Målet i dialogen er ligesom i det generelle forældresamarbejde at skabe fælles forståelser og løsninger sammen, men nogle gange er det også nødvendigt for institutionen at give bestemte retningslinjer. Dette kan være en udfordring i samarbejdet, men beskrives langt oftere som nemt, hvis forældrene bliver respekteret for deres kompetencer. Når der er en respektfuld og tillidsfuld dialog, er der faktisk blandt de udsatte børns forældre en stor efterspørgsel på vejledning og st $\varnothing$ tte fra institutionens side.

Samarbejdet med de udsatte børns forældre består i en række aktiviteter, der omfatter:

Forældresamtaler. Det er vigtigt med en meget tæt kommunikation med udsatte familier, siges det i næsten alle interviewene. Også her er den daglige kontakt vigtig - ikke mindst i forhold til at formidle informationer gensidigt, hvilket 
bedst sker i den direkte kontakt med disse familier. Nogle steder beskrives det, at samtaler skal tages her og nu, hvis der er behov for det (se ovenfor). Der foretages flere samtaler med disse forældre samt opf $\varnothing$ lgningssamtaler. I nogle tilfælde har medarbejderne brug for at reflektere over, hvordan de bedst kan varetage disse samtaler, og i de tilfælde kan de få supervision enten internt eller eksternt ved en ressourcepædagog, således at tilgangen bliver anerkendende i stedet for en problemskabende form for fejlfindingstilgang. Som det fremgår af følgende citat, bygger en styrkelse af dialogen med forældrene også på øget information:

"Lige nu har vi en, som harfået tildelt noget ekstra ekstern hjælp også, der har vi en bog, hvor vi tager billeder og sætter i hver eneste dag og skriver. Det er kontaktleddet mellem hjem og institution, sådan at de kan se, hvad har vi rent faktisk lavet i dag, hvad har vi snakket om, hvilket rim har han lært i dag. Og så i weekenderne eller hvis de har noget tilsvarende - konfirmation eller fisketur, så tager de også billeder og sætter $i$, så kan vi snakke om det. Så det er en udvidet meddelelsesbog. Det var bare et eksempel, jeg kunne trække frem."

Sommerfest og arbejdsaftner er gode til at skabe rum for en god dialog også med forældrene til udsatte børn. Der er generelt en opfattelse af, at forældrene til udsatte børn deltager mere i praktiske aktiviteter end i møder, og derfor er der mange steder planer om at prøve at få de udsatte familier mere med i det almene forældresamarbejde gennem aktiviteter såsom arbejdsdage og madlavningsaftner - fordi de udsatte forældre her kan deltage med noget, som de er gode til.

Der er desuden netværksm $\varnothing$ der med andre professionelle omkring disse familier. Det understreges, som i det følgende, af flere, at det er særdeles vigtigt at have et godt tværfagligt samarbejde for at kunne st $\varnothing$ tte familierne og dermed barnets trivsel bedst muligt:

"Vi har arbejdet med netværksmøder hver 3. måned, hvor vi er meget tværfagligt sammen og får koordineret indsatsen - det her det handler meget om de udsatte børn, vil jeg sige - der synes jeg tit, det har en effekt, at vi ved, hvad hinanden går og laver, og vifår aftalt: Det er det, jeg tager mig af, og det er det du tager dig af-og det her det er målet, det er det, vi gerne vil opnå. Så synes jeg tit, det fungerer godt. Det er rigtig vigtigt, at vi har tillid til hinanden i den tværfaglige gruppe. At alle tænker, alle gør det, de er bedst til i arbejdet med familierne."

Det nævnes ligeledes af flere, at det er vigtigt, at forældrene kan deltage i disse møder. En leder udtaler: 
"Altså, det kan være os der beder om lige at få en snak om noget hen ad vejen, men ellers så hvis forældrene de lige synes der er noget der sådan lige, de ikke lige helt, der ikke lige funker eller, de kan godt lide at snakke om hvordan barnet det reagerer lige i øjeblikket... sådan ligesom lægger op til at så kan de altså altid komme. Og ikke bare lige garderobesnakken, men også lige på .....og få en snak. Og så ellers inddrage dem, altså være meget åben omkring hvis der er nogle ting, altså det er ikke noget man går og snakker bagom eller... Og også til fx de der tværfaglige $m \varnothing-$ der som jeg siger, jamen har vi også, ikke altid, men meget gerne have forældrene med. Så de også hører hvad det er vi snakker med psykologer og sagsbehandlere om og sådan noget."

Hjemmebes $\varnothing$ g er en aktivitet, som foretages i et mindre antal institutioner. Ved hjemmebes $\emptyset$ gene vejledes der i konkrete fremgangsmåder i samspillet med barnet, således at dets sociale udvikling stimuleres i en god retning. Det er dog kun få institutioner, der selv varetager dette. I de fleste tilfælde kan dette ske ved, at kommunen bevilger en 'hjemme-hos'er' til familien. En leder udtaler i den forbindelse:

"Vi har forældre, hvor det er os, der primært kører vejledningen eller tager hjem til dem og hjælper dem... med at få børnene op om morgenen, eller hvis de har ulvetime og ikke kan styre børnene, når der skal laves mad, hvordan gør man det."

I nogle institutioner er der særlige aktiviteter for udsatte forældre. Følgende citater giver eksempler på dette:

"Så har vi også noget, der hedder "Tilbud til unge mødre" ude i min institution. Der kører vi jo også sådan en mødesekvens hver 3. måned, hvor sundhedsplejersken, sagsbehandleren, os og den unge mor deltager, hvor vi også arbejder meget med mor-barn relationen og udviklingen der. Så har vi et tilfælde, hvor forældrene har givet udtryk for, der var ting, der var svære-også der hjemme. Så har jeg sommetider sagt, jeg vil gerne give råd og vejledning, hvis I har lyst. Og så har jeg haft et par familier, hvor jeg har givet råd og vejledning - blandt andet om at alt går op $i$ hat og briller, når man kommer hjem, og det er et mareridt og man næsten ikke får lyst til at hente sit barn og man ved, det bliver et helvede, når man kommer hjem. Hvad kan det så skyldes? Hvad kan man gøre ved det rent praktisk? Og så mødes med dem til nogle ekstra snakke om: Prøv at gøre sådan og sådan og se om det hjælper. Jeg vil sige, at jeg ikke ser, at noget ikke er en mulighed."

Følgende lange citat belyser ligeledes særlige aktiviteters udformning og betydning: 
"Og så har vi de der forældregrupper. Vi har en forældregruppe, der fortrinsvis er mødre, der bliver undervist $i$ det der relationsorienterede og anerkendende pædagogik - af to personaler, som underviser dem i det, og i det teoretiske forløb, det er de i gang med om foråret, det gør de 5 gange, og de skal køre 5 gange til efteråret, hvor videoen kommer på. De tager video med hjem og så optager de sig selv sammen med barnet, og så sidder de og snakker om det. De er seks - maks. otte. Så sidder de fem andre og kigger på. Så skal man sige det, der fungerer. Forældrene har forinden pillet de gyldne øjeblikke ud selv-og så er det det, de skal se. Det er måske fem minutter. Det kan de få hjælp til af en pædagog, hvis de ikke kan selv-alt det tekniske. De skal selv være dem, der vælger ud. Og så sidder pædagogerne og de andre forældre og danner team, og så skal man prøve at sige: Prøvog kig, hvordan hun ser dig i øjnene, hvordan hun smiler - der blev hun godt nok glad, da du sagde det. Så kommer man med kommentarer. Så kan man måske sige: Oplever du det tit? Det er den gruppe, og så kører vi en anden gruppe, hvor vi har små børn - altså legestue, det er vuggestue hvor børn og forældre er med. Og så kører de forskellige temaer: Lige nu har de babymassage og motorisk udvikling. Nogle gange kører vi det også som en legestue, hvor man sidder mor-barn og pædagoger sammen og synger, og så er der fri leg, og så spiser man."

I nogle institutioner arbejdes der meget planlagt omkring det at give en mere st $\varnothing$ ttende og inkluderende opfattelse af de udsatte børn blandt forældregruppen som helhed, da dette ses som vigtigt for at kunne forbedre udviklingsmulighederne for de udsatte børn. Mht. udsatte børns forældre arbejdes der med forældremøder med fokus på det positive i andre børns rummelighed over for et barn, der er problemer med - for på den måde at styrke inddragelse/inklusion af de svage forældre, når de andres forældres forståelser ændres.

Der arbejdes også direkte med at sætte forældrene sammen, således at der kan opnås en større kompetence igennem det at hjælpe hinanden og se hinanden i nye situationer. Tre citater kan belyse dette:

"Vi kan hjælpe med at sætte dem sammen, eller hvis en mor hun ikke lige ved hvordan hun skal lægge et par bukser op, eller sådan noget, jeg ved lige at Peters mor kan hjælp med det."

"Sommetider skal forældre gøres opmærksomme på de andre forældre, før de ser deres kvaliteter."

"Vi giver forældre nogle opgaver, $f x$ skaffe ting til et julearrangement, så de andre børn/forældre får øje på dem på en ny måde/deres ressourcer." 
Opsummerende består forældresamarbejdet omkring udsatte børn i at have en god dialog, hyppigere forældrem $\varnothing$ der samt netværksm $\varnothing$ der. Endvidere består det $i$ at lave arbejdsdage og andre praktiske arrangementer, hvor andre end blot verbale ressourcer kan bruges. Dette er dog stadig snarere et $\varnothing$ nske end gennemf $\varnothing \mathrm{rt}$ mange steder. Der er også særlige aktiviteter for udsatte familier såsom grupper for mødre og par samt aktiviteter, hvor forældre kan deltage i aktiviteter og samspil med deres barn i institutionen. Disse særlige tiltag findes dog kun i meget få institutioner. Afsluttende kan det citeres fra et af interviewene: "Nærhed, tillid, kommunikation - det er vejen frem i forældresamarbejdet omkring udsatte børn".

\subsection{UDFORDRINGER I FORHOLD TIL FORÆELDREINDDRAGELSEN}

I interviewene nævnes en række konkrete udfordringer i forhold til forældresamarbejdet. Disse udfordringer samler sig i tre grupper:

- Udfordringer fra forældreside - hvilket omfatter dels forældregruppen generelt, dels specifikt forældrene til udsatte børn.

- Udfordringer omkring ressourcer såsom tid og $\varnothing$ konomi.

- Udfordringer hos medarbejderne.

\section{Udfordringer hos forældregruppen}

Det er - på baggrund af beskrivelserne i interviewene - generelt et problem, at forældrene ses som meget travle og derfor ofte ikke prioriterer det at komme til forældrem $\varnothing$ der og forældrearrangementer.

En anden type udfordring er, at forældrene flere steder beskrives som præget af en høj grad af individualisme, dvs., at de ikke ser på fællesskabet, men kun på deres eget barns muligheder, som det $f \varnothing$ lgende citat viser:

"Hvis vi tager i forhold til det generelle, så er den store udfordring, som har været der $i$ et stykke tid, det er den stigende individualisering. Det er at man er sig selv nok, og at man i høj udstrækning ikke tænker på, jamen hvad kan barnet blive til og ikke tænker så meget på og så sige, jamen hvordan bliver barnet til noget. Jeg kan godt lide det der Kierkegaards citat omkring og så sige: enhver kan blive til noget, men altså det er hårdt arbejde at blive til nogen. At man på en eller anden måde tager udgangspunkt $i$ og så sige, jamen det arbejde med en selv $i$ forhold til hele socialiseringen, i forhold til hele gruppen, det er der meget lidt fokus på $i$ øjeblikket. Det er hvordan det ser ud som om, på overfladen. Det synes jeg er en 
udfordring. Det synes jeg også bliver en ekstra udfordring i forhold til de svage grupperinger, altså de udsatte familier, de udsatte børn, fordi... altså allerførst så kommer man til at måle sig i forhold til nogen og ikke måle sig i forhold til og så sige: hvordan får jeg et godt liv, men hvem er det så jeg skal være efter?"

Forældrene ser ikke barnet som en del af en social kontekst. De ser ikke betydningen af fællesskabet - for alle børnene og dermed også for deres eget barns muligheder. En leder udtrykker det således:

"Forældre kan lære børnene rigtigt meget om at læse og tegne og skrive, men de kan ikke lære dem at være sociale, det skal vi være med til at lære dem i institutionen. Og hvis de ikke er indstillet på den der fællesskabsfølelse, så kan der godt komme nogle kampe. Jamen, bare en almindelig dag, vi skal af sted på tur, hvor nogen ikke kan finde ud af at komme til tiden, hvor de andre børn står og venter: Mit barn havde ikke lige lyst til at komme til tiden, og jeg ville ikke skynde på det. Uden at tænke på, du udsætter de andre børn, for at sidde og trille tommelfingre. Eller de er gået, og så kan de ikke forstå, vi har prioriteret gruppen frem for at sidde og vente."

Dette er - som næste citat viser det - forstærket af det, man nogle steder omtaler som "projektbørn", dvs. børn, der skal opfylde forældrenes ambitioner:

"Jeg synes jo vi har en udfordring $i$ at lære de forældre $i$ vores område at deres barn ikke altid kan komme først. Altså, og vi kan ikke altid tage hensyn til lige præcis deres barn, og det er der, det er nok der, hvor jeg tænker, det har de sværest ved at forstå fordi det jo er deres projekt, vi står med her og de vil gerne gøre det så godt som muligt."

I nogle få institutioner beskriver man disse børn som en ny type udsatte børn. Det fortælles, at det er svært at have den tidligere omtalte åbne og respektfulde dialog med forældrene til disse børn, da de som forældre skyder skylden for ethvert problem over på de andre - børn, forældre, institutionen:

"Der er den udfordring, at alle forældrene har deres lille øjesten, og de har svært ved at se at det er fællesskabet her, der er vores første prioritet. De ser måske, at der er nogen, der reagerer lidt...: Skal de ikke fjernes? Eller kan vi ikke få noget støtte på dem? Og det kan ikke være rigtigt, mit barn skal gå her og måske ikke få den største udfordring, fordi der måske er andre, der skal have noget mere støtte. Det, synes jeg, er den største udfordring. Der er måske nogle forældre, der har noget mere overskud og kan se, at der er ide i at være sociale på den led, og der er også nogen, der er hamrende ligeglade; mit barn først." 
Der ses endvidere en udfordring i, at mange forældre i dag vælger at lade deres barn skifte institution - netop pga. at barnet bliver et projekt, og man hele tiden søger efter noget bedre. I den situation er det ekstra vigtigt med information omkring overgange, således at det ikke skader barnets trivsel. Det tager tid at skabe kontakt, forståelse og sætte udvikling i gang. Det er en generel udfordring at skabe fælles forståelse med forældrene i forældresamarbejdet. Det kan, som det vil fremgå, også dreje sig om forståelsen af, hvad der foregår i institutionen:

"Så nogle gange hvor jeg tænker alle de ting, man kan gøre for at få forældre til at mødes og sådan, det er lige før vi nogle gange skal separere dem, fordi vi synes, de er for meget sammen. Det kan også blive for meget af det gode, hvis rygterne de løber som en løbeild igennem området, ikke. Så vi plejer at sige til dem: når du hører noget nogen steder fra og du tænker det var lige godt pokkers, så er det altså her, du kommer og spørger, i stedet for at du fortæller det til din nabo. For de kan nemlig ikke forklare dig om det er rigtigt."

Det kan også dreje sig om situationer, hvor en dominerende gruppe af forældre er med til at ekskludere bestemte børn gennem samtaler om dem og direkte kontakt til institutionen omkring oplevede problemer med bestemte børn:

"På et tidspunkt oplevede vi, at det var svært for forældregruppen at rumme et bestemt barn og ikke så meget hans forældre men det her barn, fordi deres børn jo tit kom hjem og fortalte, at han slog. Og der valgte vi på et forældremøde at have hans støttepædagog med, som havde valgt nogle forskellige billeder ud fra samspilssituationer $i$ løbet af ugen og fortalte om barnet og det gode samspil, der foregik med forældregruppens børn - hvor kompetente de var, og hvor dygtige de var til at rumme ham og hvor gode de var til at lade ham komme med. Og da hun var færdig med at fortælle, kom vi andre pædagoger fra stuen med og de kunne så få lov til... hun var desværre ikke med moren - eller det ved jeg ikke, om det var desværre, det var for svært for hende at rumme, vi havde jo talt med hende om vi måtte gøre det sådan og, at det havde vi gode erfaringer med... men så bagefter kunne forældrene få lov til at spørge ind til og sige nogle af de ting, som er forbudte at sige... Men idet vi fokuserede på, hvor gode deres børn var til at håndtere det, så vendte det. Og idet vi fokuserede på, hvor svært det var for den her mor, at der aldrig var nogen, der spurgte om hendes barn kunne lege, eller stå i garderoben og høre de andre planlægge legeaftaler. Det synes jeg ændrede noget. Og det har vi også prøvet efterfølgende med udsatte børn, at det giver rigtig meget at få forældrene med."

En leder fortæller, at det ved VIDA-workshops er blevet diskuteret, hvorledes fællesskabet i forældregruppen kan forstås: 
"Altså, vi har forældre med stort overskud, og vi har børn med stort overskud sådan generelt. Vi har forældre og børn, der har overskud til at interessere sig for hinanden, men som en af mine kollegaer på en af VIDA-Basis +-samlingerne lige pludselig sidder og siger: "Jamen, egentligt så synes jeg, at mine forældre er rigtig gode til at hjælpe hinanden og til at tage hånd om hinanden, når det er svært i deres liv. Ved skilsmisser og ved dødsfald i familien og sådan noget, men det er sgu da kun ved dem, som ligner dem selv". Den havde jeg ikke lige set, men det tror jeg faktisk, at hun har ret i. At rummeligheden på en eller anden måde - men de vil jo rigtig gerne, og de her stakkels børn med autismeforstyrrelser, de bliver jo inviteret hjem som legekammerater. Der er de jo enormt rummelige. Men fik jeg en eller anden lille snottet skravl med en misbrugsmor og en alkoholiseret far ude af arbejdsmarkedet, så er jeg ikke så sikker på, at det barn ville blive inviteret med hjem."

I en række af institutionerne arbejdes der med at skabe forældrem $\varnothing$ der, der fremmer inklusion af alle - som beskrevet i afsnittet ovenfor om forældresamarbejde med udsatte børns forældre. I et enkelt tilfælde er det beskrevet, hvorledes dette også gik den anden vej, nemlig at en stor gruppe forældre - også par - фnskede at deltage i et særligt tiltag for enlige mødre. Dette var i sig selv godt, men førte også til, at fokus på det særlige for de enlige mødre forsvandt - og en del af de enlige mødre holdt op med at komme. Dette er et enkeltstående eksempel - i de andre er udfordringen snarere at skabe inklusionsmuligheder for de udsatte børns forældre i det generelle forældresamarbejde.

\section{Udfordringer hos forældrene til udsatte børn}

En del steder omtales det som en udfordring i samarbejdet med udsatte familier, at disse ikke giver sig så meget tid til at lytte og være i dialog med institutionen. Der er dog også en lang række eksempler på, at det er muligt at have en åben, respektfuld og løsningsorienteret dialog med disse forældre. I et interview siges det endda, at:

"Det er faktisk tit og ofte lettere og snakke om de svære ting med en udsat familie, end det er og snakke lidt sværere ting med en velfungerende familie."

Der er mange, der påpeger, at den daglige dialog er meget vigtig med udsatte børns forældre, og at man må være ekstra opmærksom og ops $\varnothing$ gende for at etablere og vedligeholde den. Det ses generelt som en udfordring for udsatte børns forældre, at de let bliver isolerede i forældregruppen og i deres liv i det hele taget. Dette skyldes dels den ovenfor nævnte individualisme, siges der. Det skyldes også brugen af ny teknologi samt social udst $\varnothing$ delse i direkte samvær med andre. 
Her er først et citat om teknologien og dernæst om den sociale isolation i samvær med andre:

"Jeg synes også at det er en udfordring at, jamen hele den teknologiske udvikling, jamen hvis man har et godt beredskab så giver den rigtig gode redskaber til og komme videre i livet og gøre nogle ting, men det kræver et godt beredskab, hvis man ikke har et godt beredskab så bliver det noget man isolerer sig i. Og man isolerer sig ved at man sidder og spiller spil hele natten. Både forældre og børn. Og venner... det er noget man har på Facebook, altså på den måde så synes jeg, det synes jeg også er en udfordring. Fordi du kan så sige, vores socialt svage har svært ved at håndtere den nye teknologi."

"Jeg havde en mor på et tidspunkt, hun kom fra en anden by med tre børn, og hvor hun kom bagefter en grillfest og siger: XX ved du hvad, det første gang jeg har prøvet at være til et forældrearrangement hvor der var både to forældre og en personale der snakkede med mig, jeg har aldrig prøvet det før. Prøv at forestille dig at sidde, jeg kan godt forstå hun ikke gider, ikke. Det er i hvert fald noget af det jeg synes er vigtigt. Og der tænker jeg at vi er rollemodeller, for at sige at alle kan og så sat dem: kom lige med herover, ikke. Prøv lige at se, prøv lige at smage, og hun laver mad og vi smager og se hvad hun kan, ikke. Sommetider skal forældre også gøre sig opmærksomme på de andre forældre, for de ser deres kvaliteter. Det er sådan noget af det vi fors $\varnothing$ ger."

Det er en udfordring for institutionerne at bidrage til at bryde - eller i hvert fald formindske - denne isolation. Man har mange steder observeret, at forældrene til udsatte børn ikke kommer til forældrearrangementer eller arbejdsdage. Det er, som følgende citat viser, vigtigt også med direkte henvendelser til dem for at få dem til at komme til disse arrangementer:

"Udfordringen er jo at få dem ind, endnu mere ind i fællesskabet. Det har vi set. Og vi simpelthen henvender os til nogle afforældrene, når vi fx holder sommerfest, og siger at det ville være utrolig dejligt, hvis de kom, og så kommer de som regel, når man har henvendt sig direkte til dem. Men også for at inddrage forældrebestyrelsen $i$, at de også har et ansvar for, at vi får styrket fællesskabet og få alle forældre med ind i... Så det er nok, det som vi skal i gang med her. Vi har en hel lørdag med bestyrelsen i september, hvor vi bl.a. skal have en debat om, hvordan vi kan bringe forældrene ind... for vi taber jo nogen." 


\section{Udfordringer omkring ressourcer}

Der er mange gode ideer til, hvordan man kan st $\varnothing$ tte forældresamarbejdet omkring udsatte børn (se næste afsnit), men en del steder fortælles der, at der mangler ressourcer til at gennemføre disse ideer i praksis. En leder siger i den forbindelse:

"For normeringen skal også hænge sammen, for det kan godt være, man skulle have nogle ekstra cykelture, fisketure, ekstraspecifikke arbejdsdage eller hyggegrillfester, men hver gang man gør det, trækker man normeringen væk fra de udsatte børn og andre børn i dagligdagen. Og det var egentlig det, jeg sagde for et stykke tid siden: Hold fast hvor kunne man nå længere, hvis man havde ressourcerne til det. Uden at det skal være en jammer, for vi har, det vi har. Nogle gange bliver jeg lidt låst fast i: Jeg ved jo godt, de ideer er gode, men de kan ikke føres ud i livet, for der ikke penge til det. Og jeg ved jo godt, at siger jeg: Skal vi ikke lige have syv grillfester med den her gruppe børn? Hvis jeg siger det på personalemødet er det første, der vil komme: Hvor skal vi finde timerne til det? Og jeg forestiller mig også, at der er forældre til ikke-udsatte børn, som vil sige: Hvorfor skal de timer tages fra mit barn, som helst skulle være statsminister, men nu ikke bliver det, fordi de trækker timerne væk. Det handler jo også om at finde en balance og bygge bro. Men jeg tror, der er masser af gode ideer, som kunne være rigtigt konstruktive, men det er ikke muligt at føre ud i livet."

Lederen opfatter, at der mangler ressourcer. Samtidig er det interessant at se, hvordan man administrerer de givne ressourcer forskelligt i institutionerne.

\section{Udfordringer hos medarbejderne}

Nogle af institutionerne beskriver, at dialogen med forældrene omkring mulige vanskeligheder kan være en stor udfordring for nogle af medarbejderne. Udfordringen består i, at personalet ikke har så meget viden om, hvordan man kan tilrettelægge og gennemf $\varnothing$ re disse samtaler, da de ser dem som "svære samtaler" og mener, at de skal have særlige redskaber for at kunne gennemføre dem. Det konstateres samtidig, at der er en stor interesse for at lære om disse samtaler og derefter også meget st $\varnothing$ rre parathed til at tage dem.

Mht. forældresamarbejdet med udsatte børns forældre er det en udfordring at få medarbejderne til at acceptere, at disse forældre har andre kompetencer og ressourcer end pædagogerne og de andre forældres og at forholde sig respektfuldt til dette. Det omtales, at det kan være en udfordring for medarbejderne at acceptere, at nogle af disse forældre lever i en anden forståelse og livsverden, hvorfor 
de ikke bare kan gøre det, man siger til dem. Det er en udfordring for personalet at se disse forældre netop som udsatte, i stedet for at man bliver irriteret på dem. Det er svært, siges det, når pædagogernes holdninger til, hvad forældrene skal gøre, ikke mødes med umiddelbar forståelse af disse. En leder fortæller, at "når jeg skal ind og påpege nogle ting, sætte spørgsmålstegn ved forældreevnen, det synes jeg er svært". En anden leder fortæller, at "hvis forældrene undlader at gøre de ting vi aftaler - den eneste måde vi kan komme af med det på er underretninger og altså skubbe sagerne videre, så er det ude af vores hænder". Dette løses dog i mange situationer gennem dialog og ved at finde veje gennem den udfordring, det er at finde $l \varnothing$ sninger sammen, som følgende citat viser:

"Det er ikke ret lang tid siden, at jeg sad med nogle forældre, hvor de havde gjort det bedste for deres barn hele vejen igennem, men jeg ved, at de har svært ved at læse. "I skal bare lave noget dialogisk læsning derhjemme, så skal det nok gå godt", ja, men det kan de ikke. Hvad kan de så. Det er væsentligt, at de tager på fisketur og andre ting, fordi det er der, hvor de har deres del i det. Der er det vigtigt at have en forståelse for, hvad er det for nogle mennesker, som man sidder over for."

Opsummerende vedrørende udfordringer i forældresamarbejdet kan vi konkludere, at der er eksterne og interne (i institutionen) udfordringer. De eksterne udfordringer omfatter: (1) forældrenes travlhed; og (2) forældrenes opprioritering af eget barn som en modsætning til fællesskabet. De interne udfordringer omfatter: (1) forskellige holdninger blandt medarbejderne til forskelle, hvilket kan vise sig ved, at nogle medarbejdere har svært ved at udvise en anerkendende holdning - både i ord og i praksis, og (2) at man som medarbejdergruppe kan komme til at bygge videre på hinandens negative opfattelser af bestemte forældre - og derved opbygge en ekskluderende diskurs og praksis.

\subsection{MULIGHEDER I FORAELDREINDDRAGELSEN I FORHOLD TIL ARBEJDET MED UDSATTE BØRN}

Mange af institutionerne har konkrete ideer til, hvordan man kan bruge forældreinddragelsen i forhold til arbejdet med udsatte børn. De ser disse muligheder både i forhold til forældregruppen som helhed, forældre til udsatte børn, ressourcer som institutionens betingelser og medarbejderne.

\section{Muligheder i forhold til forældresamarbejdet generelt}

Generelt ser man, som omtalt ovenfor, forældresamarbejdet som en meget vigtig 
del af indsatsen for at st $\varnothing$ tte og styrke udsatte børns kognitive, sociale og emotionelle udvikling. Man inddrager både forældregruppen generelt i dette, og man inddrager forældrene til de udsatte børn i særlige aktiviteter og med $\emptyset$ get opmærksomhed på samarbejdet med dem. Ud over det, der allerede gøres, er der i interviewene mange ideer til, hvordan man kunne optimere forældresamarbejdet videre, end man gør nu.

Der er forslag til, at man gerne vil lave fyraftensmøder for alle forældre, hvor disse kan have fælles aktiviteter og være i dialog omkring det fælles, der er for både udsatte og velfungerende familier. Der foreslås også arbejdslørdage, som man meget gerne vil have flere af. Endvidere er der konkrete forslag til, at forældrene kunne mødes og bytte børnet $\varnothing$ j i institutionen, og at man kunne have flere aftener, hvor man mødes omkring madlavning, fx med fokus på mad fra forskellige kulturer.

I nogle institutioner ser man opbygningen af forældresamarbejde som relateret til en ændring af opfattelsen af daginstitutionen som et selvfølgeligt servicetilbud. I stedet kan man se på institutionen også som knyttet mere til civilsamfundets opbygning og lokale fællesskaber, hvor alle kan bidrage og ikke blot skal modtage. En leder siger i den forbindelse:

"Vi skal have forældrene meget mere på banen med det praktiske, for så får vi pædagogernes hænder fri. Men det er svært, der er jo låg over, hvad de skal betale og hvad de skal yde. Men jeg kunne godt tænke mig, vi fik en anden vane - en anden tilgang. (...) vi er nødt til at have noget praktisk på banen, så vi ikke skal tørre hylder og lamper af, male paneler og vaske vinduer - vi skal bruge tiden på det, vi er gode til, vi skal have hjælp til det andet. I: Og det mener du, forældrene kan gøre? IP: Ja, det er jo deres barns institution. Men det er en ny måde at tænke på, for de er ikke vant til det. Det ville kræve, at man tænkte anderledes. At man ikke tænkte: Jeg betaler for det, jeg har da ret til det. Jeg har nogle gange haft nogle forældre, som har sagt: Jamen jeg betaler for det. Og så siger jeg: Du betaler 25\%, kommunen betaler 75\% - du betaler slet ikke hvad det koster."

I forbindelse med opbygning af lokale fællesskaber nævner nogle ledere i interviewene i forbindelse med forældre-til-forældre-samarbejdet, at forældrene kan bruge hinanden gennem og sammen med institutionen. Dette er - som illustreret i det følgende citat - en ide, der vokser stadigt mere frem:

"Jeg tror at vejen er at gå ind og kigge på forældre til forældre, hvordan kan de gфre noget sammen? Hvordan kan vi få skabt nogle fora, hvor de kan gøre noget 
sammen. Vi har sådan en gammel ide, som jeg synes kunne være skægt at prøve af at lave noget dialoggruppe med de forældre, der har lyst, omkring, hvad oplever I af udfordringer som forældre? Få børn til at sove. Holde op med at bruge sut eller hvad det kan være."

Nogle steder fører denne ide videre til overvejelser over, om man kunne udvikle institutionen til en form for lokalt fælleshus eller kulturhus for forældrene og børnene:

"Ja, det har jeg jo tænkt meget i forhold til det her VIDA, jeg er en midtby institution. Og det indebærer at når folk bliver skilt og de bor ude i verden, så flytter de tilbage til byen, så får de deres børn ned til os. Derfor har vi en høj del af skilsmissebørn. Vi ligger som sagt også i socioфkonomisk belastet område, så derfor får vi mange af de her, og de har ikke et særlig stort netværk af velfungerende familier. Så der har jeg tænkt hvis jeg nu kunne omdanne hele børnehaven til sådan et kulturcenter, hvor der altid var nogle mennesker. Tænk nu lørdag og søndag, tænk $i$ stedet for Mikkel skal sidde i en toværelses lejlighed midt i byen, når solen skinner, fordi mor ikke orker eller ikke ved hvor de skal gå hen, fordi de ikke er vant til at gå og bruge byen, tænk hvis de bare så kunne gå ned i børnehaven, hvor de kendt. Der ville være nogen der måske har sat en grill op eller nogen der har fyldt vandbassinet. Så tror jeg jo på at de vil komme alle sammen. Altså ikke alle... Men den ene dag vil der måske komme tre, den anden, altså succeskriteriet er jo ikke at alle mennesker skal komme. Men der tænker jeg, så kunne man måske også, nogle kunne have $n \varnothing g l e n$, det behøver ikke være personalet, det kan lige så godt være en forælder der har nøglen og kan tage alarmen fra, så kan de bruge køkkenet og bage. Det tror jeg ville kunne give noget til de udsatte familier - ville kunne komme og være sammen med de andre. For de kan oftest byde ind med noget praktisk. Ikke. De er gode til at male. Vi skal male plankerne her. Det kunne vi godt tænke os. Vi bliver også nødt til at tænke nogle tanker igen hvor vi ikke kan bruge personalet en hel masse. Vi skal bare sætte rammerne. Det er ikke os der skal trække".

\section{Muligheder i samarbejdet med udsatte børns forældre}

Især i samarbejdet med forældrene til udsatte børn er der meget fokus på at inddrage dem mere i fælles forældreaktiviteter ved at have et større fokus på praktiske aktiviteter - som netop nævnt i citatet ovenfor. Grunden er, at man her oplever, at disse forældre ikke er udenfor, idet de er lige så gode til aktiviteterne som alle andre. Målet er at fremme inklusion i forældregruppen og dermed at styrke de udsatte børns forældres muligheder for at deltage i forældregruppens fælles aktiviteter på lige fod med de $\varnothing$ vrige forældre. 


\section{Ressourcernes betydning for forældresamarbejdet omkring udsatte børn}

Der er et stort $\varnothing$ nske om at kunne opbygge et st $\varnothing$ rre samarbejde med de udsatte børns forældre, men dette vil kræve flere ressourcer, anf $\varnothing$ res det fra nogle institutioner. Det nævnes, at man med flere ressourcer ville kunne arbejde meget mere med hjemmebes $\varnothing \mathrm{g}$ og st $\varnothing$ ttepersoner i familien. Dette viser, at der nogle steder er et $\emptyset$ nske om at kunne tilbyde hjemmebes $\varnothing$ g og yde konkret og praktisk vejledning til udsatte forældre både i institutionen og i hjemmet.

\section{Medarbejdernes muligheder for at bidrage til forældresamarbejdet omkring udsatte børn}

Der er nogle steder et $\varnothing$ nske om at udvikle en endnu st $\varnothing$ rre kapacitet blandt medarbejderne for at kunne møde de udsatte børns forældre på en anerkendende og løsningsorienteret måde. Der peges på et behov for i institutionen at udvikle denne kapacitet sammen - ved gensidig dialog blandt personalet, supervision og refleksioner sammen med lederen. Dette ses som en nødvendig kapacitet for at kunne opbygge og vedligeholde et forældresamarbejde med udsatte børns forældre på måder, der konstruktivt bidrager til barnets - og børnegruppens - trivsel og sunde udvikling. Der, hvor man oplever, at denne kapacitet allerede findes, er der opmærksomhed på, at den skal vedligeholdes og fortsat videreudvikles. Der nævnes supervision og kollegast $\varnothing$ tte som måder at gøre det på samt konkrete tiltag i form af planer om at skrive observationer på alle børn med et klart fokus på barnets kompetencer. Igennem dette vil det anerkendende perspektiv, der ses som yderst betydningsfuldt for samarbejdet med de udsatte børns forældre, kunne styrkes.

Opsummerende viser denne del af analysen, at man i institutionerne gerne vil udbygge forældresamarbejdet omkring de udsatte børn på følgende måder: (1) opbygge et generelt forældresamarbejde, der er inkluderende over for de udsatte børns forældre; (2) skabe muligheder for de udsatte børns forældre for at deltage i aktiviteter, hvor de kan deltage ligeværdigt, og hvor de har kompetencer til at deltage, fx i praktiske aktiviteter; (3) få muligheder for direkte, praktisk vejledning af forældre til udsatte børn og (4) bevare, styrke og videreudvikle medarbejdernes kapacitet til at varetage den anerkendende og løsningsorienterede dialog, der ses som det mest betydningsfulde i samarbejdet med forældrene til udsatte børn. 


\subsection{OPSAMLING OG KONKLUSION}

I interviewene fortælles det, at det, der fra institutionens side lægges vægt på i forældresamarbejdet, er (1) at opbygge en åben, gensidig, direkte og anerkendende dialog, fortrinsvis bygget op gennem den daglige kontakt og samtale; (2) hurtig indsats ved observerede udfordringer i trivslen for et enkelt barn og/eller i børnegruppen; (3) at der er en forløbende information omkring, hvad der foregår i institutionen samt (4) en klar og åben forventningsafstemning mellem hjem og institution.

Konkret er forældresamarbejdet organiseret som forældresamtaler, forældrem $\phi$ der og fælles arrangementer, der planlægges og gennemføres for at give informationer, skabe rum for den gode dialog og for at styrke forældre-til-forældresamarbejdet. Der er mulighed for at få samtaler med pædagogerne, hvis det $\varnothing \mathrm{n}$ skes - dog er der stor forskel på, hvornår og hvordan man som forælder kan få en sådan samtale.

Forældresamarbejdet omkring udsatte børn består i at have en god dialog, have hyppigere forældrem $\varnothing$ der og at have tværfaglige netværksm $\varnothing$ der. Endvidere består det $i$ at lave arbejdsdage og andre praktiske arrangementer, hvor de udsatte børns forældre opfordres til at deltage. Dette er dog stadig snarere et $\varnothing$ nske end gennemført mange steder. Der er også i nogle daginstitutioner særlige aktiviteter for udsatte familier såsom grupper for mødre og par samt aktiviteter, hvor forældre kan deltage i aktiviteter og samspil med deres barn i institutionen. Disse særlige tiltag findes dog kun i meget få institutioner.

Det beskrives videre i interviewene, at der er bestemte udfordringer mht. at få forældresamarbejdet til at fungere optimalt. Disse er både eksterne og interne. De eksterne udfordringer omfatter: (1) forældrenes travlhed og (2) forældrenes opprioritering af eget barn, som ses som en modsætning til fællesskabet. De interne udfordringer omfatter: (1) at nogle medarbejdere har svært ved at udvise en anerkendende holdning både i ord og i praksis, og (2) at man som medarbejdergruppe kan komme til at bygge videre på hinandens negative opfattelser af bestemte forældre - og derved opbygge en ekskluderende diskurs og praksis.

Med hensyn til mulighederne for at styrke udsatte børns trivsel igennem et godt forældresamarbejde så vi i interviewene, at man gerne vil udbygge ved at (1) opbygge et generelt forældresamarbejde, der er inkluderende over for de udsatte børns forældre, (2) skabe muligheder for de udsatte børns forældre for at indgå i aktiviteter, hvor de kan deltage ligeværdigt, og hvor de har kompetencer til at 
deltage, fx i praktiske aktiviteter, (3) få muligheder for mere direkte, praktisk vejledning af forældre til udsatte børn enten i institutionen eller i hjemmet og (4) bevare, styrke og videreudvikle medarbejdernes kapacitet til at varetage den anerkendende og løsningsorienterede dialog, der ses som det mest betydningsfulde i samarbejdet med forældre til udsatte børn.

Igennem interviewene tegner der sig således et klart billede af, hvorledes forældresamarbejdet generelt bliver set indefra i dagtilbuddene.

Det træder tydeligt frem, at det vigtigste i forældresamarbejdet er den åbne, respektfulde og løsningsorienterede dialog. Samtidig gives der udtryk for, at dialogen er vigtig, fordi der er sider af barnets liv, som ikke ses fra henholdsvis institutionens side og forældrenes side. Institutionen ser ikke, hvordan barn og forældre fungerer sammen i familien - og forældre ser ikke barnets sociale liv og udvikling i institutionen. Det nævnes, at forældregruppen kan komme til at bidrage til eksklusion ved at have meget fokus på deres eget barn og ikke på fællesskabet - og ved i nogle tilfælde at være aktivt stemplende og problemfokuserede omkring bestemte børn (og forældre) i institutionen. Derudover er der et fokus på mulighederne for, at daginstitutionen bidrager til at opbygge et forældrefællesskab, der er inkluderende og anerkendende.

Ud over dette ser man i institutionerne samarbejdet med de udsatte børns forældre som et anliggende for daginstitutionens medarbejdere sammen med andre professionelle i de tværfaglige netværk. Dette sker gennem $\emptyset$ get opmærksomhed og endnu mere dialog end med de $\varnothing$ vrige forældre. Der anvendes en anerkendende og løsningsorienteret dialog - hvilket dog godt kan være en stor udfordring at deltage i for både forældrene og for medarbejderne. Medarbejderne kan have svært ved at fastholde denne form for dialog og i stedet blive problemfokuserede i deres samtaler omkring disse børn og familier, mens forældrene kan trække sig fra dialogen.

For at invitere de udsatte børns forældre ind i forældresamarbejdet i det hele taget, foreslås det mange steder, at der skal opbygges flere forældrearrangementer med et mere praktisk fokus end et blot verbalt. Der er dog stadig en udbredt erfaring med, at de udsatte børns forældre kun deltager, hvis de specielt opfordres til dette.

Det markante fokus på dialog i forældresamarbejdet åbner samtidig for en videre udbygning af forståelsen af, hvad en dialog grundlæggende er, og hvad der 
specielt kendetegner den styrkende og løsningsorienterede dialog i forældresamarbejdet omkring udsatte børn. Endvidere kan det konkluderes, at mange af institutionerne ser en udviklingsmulighed i at styrke de udsatte børns forældre i det almene forældresamarbejde og derved skabe en inklusionsproces dér - der løber som en fælles, men parallel proces i forhold til inklusionen af de udsatte børn i børnefællesskabet i institutionen. At skabe muligheder for dette - og finde veje til at gøre det - ses som en udviklingsmulighed i forældresamarbejdet omkring udsatte børn med henblik på at skabe gode muligheder for sund kognitiv, social og emotionel udvikling for alle børnene. Dette belyses i det følgende ledercitat, som vi vil afslutte med, da det er klart og samtidig åbner for det nævnte perspektiv i forældresamarbejdet omkring udsatte børn:

"Og jeg tror dybest set, at hele fællesskabstanken og det at du... du giver dig selv, du er... vi er en stor pulje og hver gang der kommer en ny ind, så er det en ny stor pulje hele tiden. Men vi tager jo hinanden alvorligt og det er den følelse, som du skal mærke." 
VIDENSBASERET INDSATS OVER FOR UDSATTE BøRN I DAGTILBUD 


\title{
SAMMENHAENGEN MELLEM DE ENKELTE BøRNS KOMPETENCER OG BøRNEGRUPPENS SAMMENSAETNING
}

\author{
Anders Holm \& Mette Friis-Hansen
}

\subsection{INDLEDNING}

I dette kapitel analyseres sammenhængen mellem hvordan de enkelte børn vurderes af pædagogerne på de forskellige mål for kompetencer og evner, og hvordan resten af børnegruppen er sammensat. Der er altså fokus på, om de andre børn i den enkelte daginstitution påvirker det enkelte barn.

Disse analyser baserer sig på data, der er indsamlet i forbindelse med det første nedslag i VIDA-projektet, altså før VIDA-Basis og VIDA-Basis +-programmerne implementeredes. ${ }^{2}$

Der er en meget stor både kvalitativ og kvantitativ litteratur om, hvordan børn (og alle andre for den sags skyld) påvirker hinanden i mange forskellige sammenhænge. I relation til VIDA-projektet bliver interaktioner mellem b $\phi$ rnene og børnene og personalet til et spørgsmål om, både hvordan personalet varetager det enkelte barns tarv og interesser, og også hvordan barnet påvirkes af og påvirker samværet med de andre børn i institutionen. Sammenhængen mellem det enkelte barns og de andre børns kompetencer kan være meget komplekse. For det første kan man forestille sig, at børnene påvirker hinanden, fx gennem leg. Her kan børnene styrke deres sociale kompetencer, men omvendt også udsætte hinanden for mobning. Det er det, der i forskningslitteraturen kaldes endogene effekter (Manski, 1993). Jo flere ressourcekrævende børn der er, jo mere negativ effekt kan man forestille sig børnenes samvær får på det enkelte barn, og om-

2 Indholdet i VIDA-Basis- og VIDA-Basis +-programmerne er beskrevet i tidligere statusrapporter, se Jensen 2011a. 
vendt jo færre ressourcekrævende børn der er, jo mere positiv effekt kan man forestille sig samværet for det enkelte barn har.

For det andet kan man forestille sig, at alle børnenes kompetencer påvirkes af, hvor dygtige pædagogerne er til at ud $\varnothing$ ve deres fag og derigennem styrke børnenes kompetencer. Dette kaldes ofte for kontekstuelle effekter.

Hvorvidt det er den ene eller anden mekanisme, der er på spil - eller evt. dem begge på én gang, kræver naturligvis oplysninger om, hvordan pædagogerne udfører deres arbejde, og hvordan børnene interagerer med hinanden. Disse oplysninger foreligger ikke i kvantitativ form i VIDA-projektet. Det er oplysninger, der naturligvis er uhyre interessante, men som er meget omfattende at indsamle, og som derfor oftest ikke foreligger i kvantitative studier (Aizer, 2008).

Vi kan derfor ikke i denne analyse adskille, hvordan og i hvilket omfang de enkelte børn påvirker hinanden, og hvordan og i hvilket omfang pædagogerne påvirker børnene, men kun om sammensætningen af børnegruppen overhovedet er relevant for det enkelte barns kompetencer, altså om der overhovedet kan påvises endogene eller kontekstuelle effekter.

Men selv disse begrænsede analyser kan have betydelig både forskningsmæssig og politisk interesse. Dels er der ikke lavet ret meget kvantitativ forskning om betydningen af børnesammensætningen på førskoleområdet - især ikke i norden (Søgaard Larsen et al., 2009), så der kan derfor være interesse for studier på dette område. Dels kan selv analyser af, hvorvidt børnesammensætningen overhovedet betyder noget, have betydning for, hvor bekymrede politiske beslutningstagere skal være for social segregering på førskoleområdet.

Analysen af, hvordan sammensætningen af børnene påvirker det enkelte barn, kan udføres på forskellige måder. Det centrale er at se på, hvordan det enkelte barns kompetencer påvirkes af de andre børns. Det kan både være via de andre børns kompetencer eller ved deres socioøkonomiske baggrund (Ammermueller \& Pischke, 2009). Man kan sagtens forestille sig, at det både er børnenes faktiske kompetencer, der påvirker det enkelte barn, og også børnegruppens socio $\varnothing$ konomiske forhold, der kan spille direkte ind på det enkelte barns kompetencer. Hvis en gruppe af børn er meget udadreagerende, kan man nemt forestille sig, at dette påvirker andre børn til enten at blive angste og mere tilbageholdende eller at lade sig rive med af den udadreagerende adfærd - i begge tilfælde overf $\varnothing$ res en negativ effekt fra de børn, som har en belastet socio $\varnothing$ konomisk baggrund samt evt. manglende kompetencer, til andre børn. 
Man kan også forestille sig, at børn med en svag socio $\varnothing$ konomisk baggrund tilf $\varnothing$ rer børnegruppen færre kreative ressourcer og input og at de andre børn derfor bliver mindre udfordret i deres sociale udvikling - selv om de socio $\varnothing$ konomisk svagt stillede børn ikke direkte påvirker de andre børns udfoldelsesmuligheder, bringer de færre input til børnenes fælles udvikling.

\subsection{STATISTISK ANALYSE}

I dette afsnit gennemføres en statistisk analyse af sammenhængen mellem det enkelte barns kompetencer og børnegruppens sammensætning i hver daginstitution.

Det enkelte barns kompetencer vurderes ud fra screeningsredskabet The Strengths \& Difficulties Questionnaire (SDQ). SDQِ'en måler børns sociale og psykiske situation, dvs., at redskabet giver en vurdering af barnets styrker og vanskeligheder i den aktuelle situation. B $\varnothing$ rnene i VIDA vurderes i tre nedslag: baseline i marts 2011, 2. nedslag i feb./marts 2012 og 3. nedslag i jan./feb. 2013, dvs., at man derved kan få et billede af børnenes udvikling over tid. Det giver samtidig en målestok for at vurdere effekterne af de VIDA-indsatser, der er blevet iværksat.

\section{THE STRENGTHS \& DIFFICULTIES QUESTIONNAIRE (SDOQ)}

SDO-skalaen er udviklet af psykolog Robert Goodman i 1999. SDO-skemaet er et spфrgeskema med 25 spфrgsmål samt fem afsluttende spørgsmål om barnets mulige vanskeligheder, som samlet set udg $\varnothing \mathrm{r}$ SDO--skalaen. De f $\varnothing$ ste 25 spørgsmål er opdelt på fem kategorier, der hver især afdækkes gennem fem spørgsmål. De fem kategorier er: 1) Emotionelle problemer, 2) Adfærdsproblemer, 3) Hyperaktivitet, 4) Kammeratskabsproblemer samt 5) Prosocial adfærd. Alle spфrgsmålene er enkle og har tre svarkategorier: 1) Passer ikke, 2) Passer delvist samt 3) Passer godt. De fem spørgsmål, som skemaet afsluttes med, fokuserer på barnets mulige vanskeligheder - vanskelighedernes sværhedsgrad, varighed og betydning for omgivelserne. Der spørges ind til, hvorvidt barnet samlet set er bebyrdet af de målte vanskeligheder, og hvorvidt vanskelighederne har en indflydelse på barnets daglige liv i hjemmet, i daginstitutionen, i forhold til kammeraterne og i forhold til fritidsaktiviteter. 


\section{THE STRENGTHS \& DIFFICULTIES OUUESTIONNAIRE (SDOQ) FORTSAT}

I hvert af de fem domæner kan barnet score mellem 0 og 10 point. Afhængig af besvarelserne på de enkelte spørgsmål opnår barnet, der vurderes, et pointtal, der indikerer, om barnet falder inden for normalområdet, befinder sig i midtergruppen eller falder uden for normalområdet inden for hver delkategori. Desuden opnår hvert barn et samlet pointtal, der bygger på delkategorierne med undtagelse af de sociale styrkesider. Den samlede score kan maksimalt udgøre 40 point (på http://www.sdqinfo.com findes en oversigt over, hvordan SDO'en scores, samt hvor mange point svarene på de forskellige spфrgsmål giver).

I VIDA udfyldes skemaet af pædagogen i det enkelte dagtilbud. Pædagogen sætter kryds ud for den svarkategori, som han/hun synes passer bedst på barnet. Vurderingen af børnenes kompetencer målt ved SDO-skalaen bygger således på pædagogens viden om og opfattelse af barnet ved det aktuelle nedslag/måling.

Den statistiske model skal belyse, om der er et sammenfald mellem det enkelte barns kompetencer og sammensætningen af resten af børnegruppen, altså om andre børns karakteristika og kompetencer spiller en rolle for det individuelle barns kompetencer. Sådanne analyser er aldrig lavet i Danmark, fordi data om førskolebørns kompetencer og karakteristika ikke f $\varnothing \mathrm{r}$ har været tilgængelig for hele institutioner. Der findes international litteratur, der belyser effekten på børns udvikling af sammensætningen af børnegruppen i førskoleinstitutioner, Neidell og Waldfogel (2010). Heraf fremgår det, at børnenes kompetencer i grundskolen er påvirket af, hvordan børnegruppen har været sammensat i forskoleinstitutionerne.

Umiddelbart virker det oplagt at analysere sammenfald mellem det individuelle barns kompetencer og resten af børnegruppens kompetencer. Den afhængige variabel er det enkelte barns kompetencer, målt fx ved de forskellige domæner i " The Strengths and Difficulties Questionnaires" (SDQ, se mere på http:// www.sdqinfo.com). De uafhængige variabler er de andre børns kompetencer, fx målt ved det gennemsnitlige niveau for de andre børn. Men den kausale orden for denne model er uklar. Er det de andre børn, der påvirker det enkelte barns kompetencer, eller er det omvendt det pågældende barn, der har påvirket de andre børns kompetencer. Det er således umuligt på forhånd at sige, hvilke børns kompetencer der er den afhængige variabel, og hvilke børns kompetencer der er 
de uafhængige variabler. Dette fænomen er endogenitetsbias, som fremkommer ved, at vi ikke på forhånd kan sige, hvilke børn der påvirker hvilke børn, og om der er nogle børn, der kun modtager påvirkning fra andre børn og ikke påvirker de andre.

Så vi kan altså ikke bruge de andre børns kompetencer som uafhængig variabel. I stedet bruger vi de andre børns baggrundskarakteristika, dvs. de andre børns socio $\varnothing$ konomiske baggrund, andelen af drenge, andelen af etniske minoriteter osv. som forklarende variabler. Disse variabler repræsenterer både evt. endogene effekter, altså at børnenes kompetencer påvirker hinanden, og også at deres baggrundskarakteristika har en selvstændig effekt på det enkelte barns kompetencer. I tabel 1 vises regressionsresultaterne for effekten af børnegruppens baggrundskarakteristika på de enkelte børns kompetencer, som de kan måles gennem de forskellige domæner i SDOِ'en.

Inden resultaterne i tabel 3 gennemgås, er det vigtigt at huske på, at alle fortolkningerne af de observerede effekter af børnegruppens sammensætning afhænger af, at der ikke er uobserverede variabler, der påvirker alle børnene på samme måde, motiverede forældre der både vælger de samme institutioner, og som også har børn med bedre kompetencer. På den måde kommer de observerede variabler for børnesammensætningen blot til at afspejle, at motiverede forældre med velfungerende børn har en tendens til at have deres børn i de samme institutioner, og omvendt at mindre motiverede forældre med mindre velfungerende børn har deres børn gående i de samme institutioner. På den måde kan man forestille sig, at børnesammensætningen i stedet for at afspejle endogene effekter eller kontekstuelle effekter blot afspejler, at bestemte forældre har deres b $\emptyset$ rn gående i de samme institutioner. 
Tabel 3. Estimationsresultater

\begin{tabular}{|c|c|c|c|c|c|c|c|c|c|c|}
\hline & \multicolumn{2}{|c|}{$\begin{array}{l}\text { Emotionelle } \\
\text { problemer }\end{array}$} & \multicolumn{2}{|c|}{$\begin{array}{l}\text { Adfærds- } \\
\text { problemer }\end{array}$} & \multicolumn{2}{|c|}{ Hyperaktivitet } & \multicolumn{2}{|c|}{$\begin{array}{l}\text { Kammeratskabs } \\
\text { problemer }\end{array}$} & \multicolumn{2}{|c|}{$\begin{array}{l}\text { Prosocial } \\
\text { adfærd }\end{array}$} \\
\hline & $\begin{array}{l}\text { Esti- } \\
\text { mat }\end{array}$ & Sd fejl & $\begin{array}{l}\text { Esti- } \\
\text { mat }\end{array}$ & Sd fejl & $\begin{array}{l}\text { Esti- } \\
\text { mat }\end{array}$ & Sd fejl & $\begin{array}{l}\text { Esti- } \\
\text { mat }\end{array}$ & Sd fejl & $\begin{array}{l}\text { Esti- } \\
\text { mat }\end{array}$ & Sd fejl \\
\hline & \multicolumn{10}{|c|}{ Variabler der beskriver individuelle effekter } \\
\hline Konstantled & $3,095^{*}$ & (1.095) & $3,010^{*}$ & $(0,923)$ & $5,706^{*}$ & $(1,416)$ & $3,104^{*}$ & $(0,923)$ & $5,545^{*}$ & $(1,503)$ \\
\hline Pige & $-0,189^{*}$ & $(0,047)$ & $-0,285^{*}$ & $(0.024)$ & $-1,320^{*}$ & $(0,066)$ & $-0,285^{*}$ & $(0,044)$ & $1,283^{*}$ & $(0,057)$ \\
\hline Alder & $0,065^{*}$ & $(0,026)$ & $0,081^{*}$ & $(0,020)$ & $-0,232^{*}$ & $(0,037)$ & $-0,098^{*}$ & $(0,025)$ & $0,469^{*}$ & $(0,032)$ \\
\hline $\begin{array}{l}\text { Moders uddan- } \\
\text { nelse i antal år }\end{array}$ & $-0,090^{*}$ & $(0,016)$ & $-0,079^{*}$ & $(0,012)$ & $-0,237^{*}$ & $(0,022)$ & $-0,087^{*}$ & $(0,015)$ & $0,131^{*}$ & $(0,019)$ \\
\hline $\begin{array}{l}\text { Etnisk } \\
\text { minoritet }\end{array}$ & $-0,094$ & $(0,064)$ & $-0,103^{*}$ & $(0,049)$ & 0,098 & $(0,090)$ & 0,062 & $(0,060)$ & $-0,095$ & $(0,078)$ \\
\hline VIDA-Basis & 0,018 & $(0,123)$ & 0,122 & $(0,079)$ & 0,247 & $(0,161)$ & $-0,018$ & $(0,103)$ & $-0,108$ & $(0,203)$ \\
\hline VIDA-Basis + & $-0,212$ & $(0,133)$ & $-0,016$ & $(0,079)$ & $-0,016$ & $(0,161)$ & 0,050 & $(0,103)$ & 0,234 & $(0,204)$ \\
\hline
\end{tabular}

\section{Variabler der beskriver sammensætningseffekter}

\begin{tabular}{|c|c|c|c|c|c|c|c|c|c|c|}
\hline $\begin{array}{l}\text { Gns uddannel- } \\
\text { seslængde for } \\
\text { mødre }\end{array}$ & $-0,306^{*}$ & $(0,078)$ & $-0,103^{*}$ & $(0,050)$ & $-0,359^{*}$ & $(0,099)$ & $-0,276^{*}$ & $(0,064)$ & 0,120 & $(0,112)$ \\
\hline $\begin{array}{l}\text { Andel børn af } \\
\text { etniske minori- } \\
\text { teter }\end{array}$ & $-0,447$ & $(0,340)$ & $-0,014$ & $(0,214)$ & $-0,609$ & $(0,426)$ & 0,153 & $(0,275)$ & $-0,785$ & $(0,496)$ \\
\hline Andel piger & 0,087 & $(0,610)$ & $-0,025$ & $(0,400)$ & $-0,610$ & $(0,784)$ & $-0,436$ & $(0,510)$ & $-0,148$ & $(0,844)$ \\
\hline $\begin{array}{l}\text { Gennemsnitlig } \\
\text { alder på børnene }\end{array}$ & 0,099 & $(0,236)$ & 0,144 & $(0,158)$ & 0,284 & $(0,307)$ & 0,018 & $(0,200)$ & $-0,114$ & $(0,319)$ \\
\hline $\begin{array}{l}\text { Spredning på } \\
\text { uddannelses- } \\
\text { længde for }\end{array}$ & $-0,057$ & $(0,205)$ & $-0,055$ & $(0,128)$ & $-0,022$ & $(0,256)$ & $-0,102$ & $(0,165)$ & 0,118 & $(0,300)$ \\
\hline
\end{tabular}

\section{Varians parametre}

$\begin{array}{lllllllllll}\text { Standardafvi- } \quad 0,465^{*} & (0,047) & 0,244^{*} & (0,032) & 0,527^{*} & (0,059) & 0,331^{*} & (0,040) & 0,761^{*} & (0,065)\end{array}$ gelse, Instituti-

onsniveau

$\begin{array}{lllllllllll}\text { Standardafvi- } \quad 1,916^{*} & (0,017) & 1,469^{*} & (0,013) & 2,704^{*} & (0,023) & 1,804^{*} & (0,016) & 2,331^{*} & (0,020)\end{array}$ gelse, Barn

Note: Der indgår i alt 6.820 børn i analysen fordelt på 106 institutioner. Der er i gennemsnit 64,3 børn pr. institution. * indikerer signifikans på 5\% eller mindre. 
I tabel 3 ses sammenhængen mellem børnenes baggrundskarakteristika, børnegruppens karakteristika og børnenes kompetencer, som de er målt ved de fem domæner i SDQ’'en. Børnenes egne karakteristika måles ved deres k $\varnothing$ n og alder, moderens uddannelsesniveau, og om de tilhører en etnisk minoritet. Børnegruppens sammensætning i hver institution måles ved den gennemsnitlige uddannelseslængde for mødrene, andelen af piger, andelen af børn fra etniske minoriteter, børnenes gennemsnitlige alder og spredningen på mødrenes uddannelsesniveau. Der kontrolleres i analyserne også for, om børnene går i institutioner, der deltager i VIDA-Basis-programmet eller VIDA-Basis +-programmet, eller om de går i institutioner i kontrolgruppen. Disse variabler opfanger forskellene mellem hhv. VIDA-Basis og VIDA-Basis + og kontrolgruppen.

Når børnenes baggrundskarakteristika måles ved moderens uddannelsesniveau, men ikke fx faderens eller familiens $\varnothing$ konomiske situation, er det, fordi tidligere analyser har vist, at det kun er moderens uddannelsesniveau, der spiller en rolle for børnenes kompetencer. Når der kontrolleres for moderens uddannelsesniveau spiller faderens uddannelse eller familiens $\varnothing$ konomiske situation ikke nogen rolle.

Af tabel 3 ses, at piger generelt er mere velfungerende end drenge, de ligger mellem 0,2 og 1,3 point bedre placeret på de fem domæner i SDO'en; de har færre emotionelle og adfærdsproblemer, de er betydeligt mindre hyperaktive, de har færre kammeratskabsproblemer, og de er markant mere prosociale.

Jo ældre børnene bliver, jo flere emotionelle og adfærdsproblemer udviser de. Dette observeres generelt i litteraturen (March, 1985). Dette kan skyldes, at det kan være svært at aflæse helt små børns emotionelle problemer, og at de simpelthen er for små til at udvise adfærdsproblemer.

Omvendt er ældre børn mindre hyperaktive og har færre kammeratskabsproblemer, og de er mere prosociale. Dette er formentligt, fordi ældre børn har en st $\varnothing$ rre forståelse for deres sociale relationer og derfor er bedre til at indordne sig i daginstitutionernes hverdag.

Jo bedre moderen er uddannet, jo bedre klarer børnene sig på alle fem domæner i SDO. Veluddannede mødres børn har simpelthen generelt bedre kompetencer end kortere uddannede mødres. Der kan være mange årsager til denne sammenhæng. En forklaring kan være, at højt uddannede mødre i højere grad end kortere uddannede mødre stimulerer deres børn mere og styrker dermed deres kompe- 
tencer. En anden forklaring kan være, at veluddannede mødre videregiver deres kompetencer genetisk, således at deres børn helt fra fødselen har genetiske anlæg for at udvikle bedre kompetencer end kortere uddannede mødres (Haworth, 2011). Nyere forskning peger på, at der også kan være tale om en genetisk og miljømæssig interaktion (Haworth, 2011).

Børn fra etniske minoriteter har generelt ikke anderledes kompetencer end børn fra ikke-etniske minoriteter. Men i VIDA ser de dog ud til at have lidt færre adfærdsproblemer. Dette forhold er nærmere diskuteret i Jensen et al., 2011b.

Børnene i institutioner i VIDA-Basis- og VIDA-Basis +-programmerne har ikke anderledes kompetencer end børnene i kontrolgruppen. Dette afspejler blot, at programmerne ikke var implementeret på det tidspunkt, hvor data til denne analyse blev indsamlet, samt at tildelingen til de to programmer og kontrolgruppen er sket på basis af lodtrækning.

$\mathrm{B} \phi \mathrm{rn}$ i institutioner, hvor mødrene generelt er veluddannede, har bedre kompetencer end børn, hvis mødre er kortere uddannede. Dette kan fx ses for emotionelle problemer. Her er regressionskoefficienten for den gennemsnitlige uddannelseslængde for mødrene på -0,306 og statistisk signifikant. For hvert år den gennemsnitlige uddannelseslængde stiger blandt mødrene, så falder børnenes emotionelle problemer med 0,3 point. Dette kan som ovenfor nævnt skyldes endogene effekter, altså at børnene påvirker hinanden positivt, hvis der er mange veluddannede mødre, og mere negativt, hvis der er flere kortuddannede mødre. Det kan også skyldes, at jo flere veluddannede mødre, der har børn i den enkelte institution, jo flere ressourcer har personalet i institutionen til at styrke børnenes kompetencer, fx fordi de skal bruge mindre tid på basale pasningsopgaver og kan bruge mere tid på at styrke børnenes kompetencer. Men det er vigtigt at huske på, at denne analyse ikke kan påvise, om det er den ene type (endogenitet) eller den anden type forklaring, der er den rigtige. Det kan heller ikke udelukkes, at den signifikante effekt af mødrenes uddannelsesniveau i virkeligheden skyldes sammenklumpningseffekter - altså at veluddannede mødre har nogle andre kompetencer, som vi ikke har oplysninger om, og som påvirker børnenes kompetencer - og hvor mødrenes gennemsnitlige uddannelsesniveau bliver en proxy for børnenes kompetencer.

Tabel 3 viser, at der ikke er effekter på børnenes kompetencer i forhold til, om der er mange eller få piger eller mange eller få børn fra etniske minoriteter. Der er heller ikke nogen effekt af børnenes gennemsnitlige alder. Det betyder altså ikke noget for det enkelte barn at gå i en institution med mange eller få mindre børn. 
Man kunne forestille sig, at mange små børn ville binde personalets ressourcer i mere basale pasningsopgaver og derfor ville stjæle ressourcer fra det mere pædagogiske arbejde, og at dette kunne lede til ringere kompetencer hos det enkelte barn. Men det ser ikke ud til at være tilfældet.

Endelig er der heller ikke nogen effekt fra spredningen af mødrenes uddannelsesniveau. Tanken med at inkludere denne variabel var, at man kunne forestille sig, at et højt uddannelsesniveau blandt mødrene - målt ved den gennemsnitlige uddannelseslængde for mødrene - ville have en forskellig effekt, alt efter om den er genereret af få meget veluddannede mødre (en høj spredning på mødrenes uddannelsesniveau) eller flere mødre med mellemlange uddannelser (en lav spredning på mødrenes uddannelsesniveau). Men mens mødrenes gennemsnitlige uddannelsesniveau ser ud til at hænge sammen med børnenes kompetencer, spiller spredningen ingen rolle. Der opnås m.a.o. den samme effekt fra få veluddannede mødre som fra mange mødre med mellemlange uddannelser.

De estimerede modeller er såkaldte multilevelmodeller (Goldstein, 2010). Disse modeller korrigerer den statistiske usikkerhed for, at børnene ikke er tilfældigt udvalgt, men er indlejret i daginstitutioner. Dette giver normalt anledning til st $\varnothing$ rre statistisk usikkerhed. Fra multilevel-modellerne får man også information om den statistiske spredning på børnenes kompetencer fordelt på spredning mellem institutioner og spredning mellem børn. Af tabel 3 kan man se, at den st $\varnothing$ rste spredning ligger mellem børnene. Institutionerne bidrager altså kun i

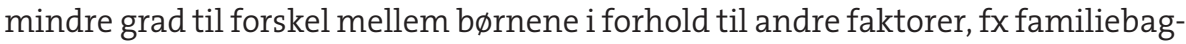
grund, genetiske dispositioner osv.

Man kunne forestille sig, at sammensætningseffekterne er forskellige for udvalgte grupper af børn. I mange analyser af peer-effekter ses det, at det især er udsatte grupper, der påvirkes af sammensætningseffekter, Schneeweiss og WinterEbmer (2007), Lavy et al. (2012). Derfor er der lavet særskilte analyser af den statistiske model, der er vist i tabel 3 for udvalgte grupper, for hvem det på forhånd vurderes, at sammensætningseffekterne kan være særligt udtalte. Det drejer sig om drenge, børn fra etniske minoriteter og børn af ufaglærte mødre. Generelt viste analyserne ikke et andet billede end det, der kan ses for hele børnegruppen i tabel 3. Der findes ingen særskilte sammensætningseffekter for drenge eller børn af etniske minoriteter. Men for børn af ufaglærte mødre ses det, at jo flere veluddannede mødre der er i institutionen, jo bedre klarer børn af ufaglærte m $\varnothing$ dre sig socialt på den måde, at disse børn har markant færre kammeratskabsproblemer og en bedre prosocial adfærd. 
Igen må der tages det forbehold, at denne analyse ikke kan fortælle om den positive sammensætningseffekt for børn af ufaglærte mødre skyldes positive peereffekter, eller om det skyldes, at de ufaglærte mødres børn i institutioner med mange veluddannede mødre er anderledes end børn af ufaglærte mødre i institutioner med mange andre børn af andre ufaglærte m $\varnothing$ dre. Man kan fx forestille sig, at ufaglærte mødre, der anbringer deres børn i institutioner med generelt veluddannede mødre, har flere aspirationer og forventninger til deres børn end ufaglærte mødre, der anbringer deres børn i institutioner med børn af mange andre ufaglærte mødre.

\subsection{DISKUSSION}

I dette afsnit er sammenhængen mellem karakteristika for daginstitutionerne, især det gennemsnitlige uddannelsesniveau for børnenes mødre og det enkelte barns kompetencer, gennemgået. Det viser sig, at det enkelte barns kompetencer er bedre, jo flere veluddannede mødre der har børn i den pågældende daginstitution. I afsnittet er årsagerne til denne sammenhæng endvidere diskuteret, og det er påpeget, at årsagerne kan være trefoldige. Det kan enten skyldes, at veluddannede mødres børn har bedre kompetencer, som forstærker det enkelte barns kompetencer. Det kan også skyldes, at jo flere veluddannede mødre der har børn i den enkelte institution, jo flere ressourcer kan personalet overf $\varnothing$ re fra basale pasningsopgaver til egentligt pædagogiske arbejde, og endelig kan det skyldes effekter af uobserverede forhold. Videre forskning i VIDA-projektet kan kaste lys over hvilke forklaringer, der er den/de rigtige. 


\title{
KAPITEL 7
}

\section{VIDA MIDTVEJSANALYSER - EN KONKLUSION}

\author{
Bente Jensen
}

I dette afsluttende kapitel samles der op på midtsvejsrapportens analyser, fund og konklusioner i relation til VIDA-projektets opstillede mål, konkrete uddannelsesforl $\varnothing \mathrm{b}$ og resultater af analyser af deltagernes (institutionernes) arbejde med projektets elementer, ideer og vision. Der er i den forbindelse fokus på, hvordan deltagerne omsætter projektet i hhv. organisatorisk læring, dvs. læring i det samlede dagtilbud, og i nye former for forældreinddragelse (VIDA-Basis +-institutionerne). Afslutningsvis bliver resultater af analyser af børnegruppens kompetencer og forhold af betydning for børns kompetenceudvikling opsummeret.

\section{VIDA-UDDANNELSE - BASERET PÅ ET ORGANISATORISK LÆERINGSBEGREB}

Formålet med den første fase i VIDA-uddannelsesforl $\varnothing$ bet har været, at deltagerne opbygger en fælles base af forskningsbaseret viden om udsatte børn. Uddannelsesforl $\phi$ bet er tilrettelagt omkring VIDA-kvalifikationsmappens f $\varnothing$ rste del, hvor der præsenteres evidensbaseret viden om 1) social arv, udsatte børn, baggrund, begrebet om læring og kompetencer, in- og eksklusion, 2) viden om effektfulde interventioner baseret på international forskning samt 3) lovgivningen på feltet. Denne forskningsbaserede viden er i undervisningen blevet bragt i spil med praktikernes både implicitte og eksplicitte erfaringsbaserede viden. Formålet med denne proces er dels, at der skabes ny teoretisk viden, og dels at deltagerne på baggrund af denne viden får mulighed for at udvikle deres pædagogiske faglighed. VIDA-projektets princip om organisatorisk læring og innovation, som beskrevet i VIDA-statusrapport 1, bliver inddraget i undervisningsmæssige sammenhænge ved, at lederen og den pædagogiske medarbejder, som deltager på uddannelsen, bringer den forskningsbaserede viden med hjem i deres institutioner. 
Intentionen bag hele uddannelsesforløbet er således, dels at deltagerne på baggrund af undervisning, de indbyggede vidensbaserede materialer og udviklingsværktøjer selv sætter fokus på at udvikle viden, refleksioner og redskaber til at arbejde med deres egen praksis, og dels at deltagerne opnår viden om, hvordan evidensbaseret viden og refleksioner kan udfoldes i dagtilbuddet og danne grundlag for nye pædagogiske praksisser i organisationen på måder, som involverer alle medarbejdere.

I VIDA bliver der ikke undervist i et færdigt interventionsprogram, som den enkelte institution skal anvende ureflekteret. Der lægges derimod op til at arbejde ud fra et aktivt læringsperspektiv, som bl.a. indebærer, at deltagerne ud fra den forskningsbaserede viden, som de er blevet præsenteret for på uddannelsen, deres refleksioner over denne vidensform og herefter kommende handlinger selv udarbejder konkrete bud på et VIDA-interventionsforl $\varnothing b$. Dette forl $\varnothing b$ baseres på retningslinierfor VIDA (Se VIDA-statusrapport 1, Guidelines, BILAG 5), men på måder, som netop passer til den enkelte institution.

I VIDA arbejdes der ud fra et aktivt læringsbegreb med udgangspunkt i den amerikanske pædagog og filosof John Deweys (1859-1952) pragmatiske erkendelsesteori og ud fra den opfattelse, at vi lærer nyt ved at tilegne os kundskab, fx i form af viden omkring et særligt emne. Det læringsbegreb, som er et centralt omdrejningspunkt for VIDA-programmet og dets uddannelsesforl $\varnothing$ b, som nu er gennemført i fase 1, bygger på tre komponenter:

- aktivitet og fællesskaber af lærende, dvs., at der er fokus på, at den lærende deltager i praktiske læringsaktiviteter og interaktion med andre.

- erfaring, dvs., at der er fokus på den erfaring, den lærende har fra tidligere samspil og situationer. Erfaring skal netop anvendes til at udvikle nye og forbedrede erfaringer.

- rekonstruktion, dvs. at den lærende anvender den erfaring, vedkommende har fra enten tidligere, lignende situationer eller nuværende til at reflektere således, at erfaringen rekonstrueres/nykonstrueres.

I VIDA uddannelsesforløbet arbejder deltagerne med et organiseret lærestof, som indgår i læringsaktiviteterne, således at deltagerne får kendskab til forskningsbaseret viden om arbejdet med udsatte børn, hvad der virker, og hvilke problematikker omkring udsathed der kan gribe hindrende ind. Som præsenteret i denne statusrapports kapitel 2, inddrager VIDA-undervisningen i h $\varnothing$ j grad deltagernes egne erfaringer via forskellige refleksionssp $\varnothing$ rgsmål, som deltagerne 
arbejder med gennem drøftelser i Refleksionsrum, gruppearbejde på tværs af institutioner og dialog mellem ledere og medarbejdere. Disse didaktiske metoder er med til, at deltagernes refleksioner igangsættes på uddannelsesforløbene, og uddannelsen lægger op til, at deltagerne får muligheder for at rekonstruere/nykonstruere de erfaringer og den viden, som er oparbejdet gennem praksis, tidligere rutiner og vaner.

Ud over et organiseret lærestof, er uddannelsen bag VIDA-programmet fokuseret på, hvilke betingelser der fremmer læring, og der er derfor lagt særlig vægt på læringskonteksten.

\section{FACILITERING AF ORGANISATORISK LAERING OG INNOVATION}

Et væsentligt mål med VIDA-uddannelsen og dens særlige opbygning er, at den bidrager til institutionernes samlede kvalitets- og kompetenceudvikling. Projektet lægger nemlig som nævnt vægt på det princip, at individuel læring på uddannelsen bliver til organisatorisk læring i det samlede dagtilbud.

Dette princip kan i praksis være en stor udfordring for dagtilbuddene, og derfor har VIDA-projektet indbygget lederkurser som en del af uddannelsesforl $\varnothing$ bet. Disse kurser, der træner lederne i facilitering, sætter fokus på et blindt punkt i mange fors $\varnothing \mathrm{g}$ på lederudvikling og organisatorisk læring.

En væsentlig forudsætning for at projektet lykkes, er, at den transfer af viden og refleksionstilb $\varnothing$ jelighed, som lederne tager med sig fra VIDAs uddannelsesforl $\phi b$, bliver kommunikeret til resten af personalet, så der skabes engagement, interesse og vilje til organisatorisk innovation. I dagtilbud har der været tradition for en kollektivt anlagt arbejdsgang, hvor en leder ikke sættes på en piedestal af sine medarbejdere, og en vigtig udfordring for lederen består derfor tilsyneladende i at spille sin lederrolle på en ny måde, som indebærer en systematisk inddragelse af medarbejdernes perspektiver og stemmer, således at den institutionelle udviklingsindsats bliver en fælles sag.

Lederkurserne i facilitering, som er gennemført som en del af VIDA-uddannelsens første fase, skal give muligheder for konkret at skabe processer til mødedeltagelse og involvering af alle medarbejdere på konstruktiv og værdiforøgende måde. Når der senere i projektforløbet vedtages ændringer i dagtilbuddets pædagogiske praksisser, skal disse ændringers skæbne, herunder deres implemente- 
ring, justeringer og fastholdelse, løbende monitoreres af ledere og medarbejdere i fællesskab. Dette kræver, at VIDA uddanner ledere til at arbejde med mødeformer af mere dynamisk og proaktiv karakter.

\section{VIDA-MIDTVEJSRESULTATER}

Udfordringerne $i$ arbejdet med at implementere VIDA i det samlede dagtilbud - ud fra perspektivet om organisatorisk læring

Midtvejsanalysen, som bygger på interview med ledere fra samtlige dagtilbud, gennemf $\varnothing$ rt sommeren 2011 umiddelbart efter afslutningen på f $\varnothing$ rste uddannelsesforl $\varnothing b$, viser, at der primært anvendes formelle læringsmetoder i dagtilbuddet f $\varnothing$ r VIDA-projektets igangsættelse. Det kan fx være at arbejde med møder i forskellig form efterfulgt af kursusaktivitet og læsning af faglig litteratur.

Der er i analysematerialet påvist tre grundformer for tilgange til arbejdet med viden, faglighed og fornyelse, som kan forventes at få en betydning for den måde, dagtilbud arbejder med VIDA-programmet på. De tre tilgange er:

En ekspliciteret teoribaseret tilgang til opgaven - som repræsenterer en formel og strategisk læringsform. Denne tilgang er karakteriseret ved, at lederen beskriver medarbejderne som en medarbejderstab, der arbejder målrettet og systematisk med børnenes læring. Institutioner, der kan rubriceres under denne grundform, er præget af høj grad af organisering og struktur i hverdagen, hvilket bl.a. giver sig udtryk i, at der tales om bevidste valg af fx gruppest $\varnothing$ rrelser, læringsrum for børn og arbejdet med børnefællesskaber, herunder arbejdet med læringsrum, der indebærer alsidige lærings- og trivselsskabende aktiviteter.

En erfaringsbaseret tilgang til opgaven - som repræsenterer en ikke-formel og en ikke-strategisk læringsform. Denne tilgang er karakteriseret ved, at lederen selv oplever ét behov for og stræber efter at højne fagligheden gennem VIDA. Institutioner, der kan rubriceres under denne grundform, arbejder med organisering, men med mindre systematiske og ikke-begrundede eller ekspliciterede strategier for praksis. Hos disse institutioner kan der imidlertid identificeres et stort behov for at blive mere bevidst om faglige begreber og et udtalt $\varnothing$ nske om at indarbejde refleksion i relation til praksis som en del af arbejdsopgaven i hverdagen fremover. 
En behovsbaseret tilgang til opgaven - som repræsenterer en ad hoc- og vanepræget læringsform. Denne tilgang er karakteriseret ved, at lederen ikke har stor tro på, at det at ændre ved praksis, som VIDA anbefaler, kan gennemføres. Vaner og rutiner opleves således som ikke-foranderlige. Praksis bygges hos disse institutioner på et princip om at tage dagen, som den kommer, og ud fra de behov fra de enkelte børn, voksne og hele situationen, som udmøntes den pågældende dag.

Der synes således helt overordnet at være forskellige forudsætninger for at indarbejde VIDA-projektet i dagtilbuddene, når vi unders $\varnothing$ ger forhold vedrørende viden, faglighed og fornyelse. For dem, der i forvejen arbejder meget målrettet og strategisk med inddragelse af viden i strategier for de pædagogiske praksisser, falder VIDA naturligt og kærkomment, mens det for andre institutioner opleves mere udfordrende, idet en mere uformel, intuitiv og erfaringsbaseret viden, der inddrages i de pædagogiske praksisser, kan opleves som længere væk fra VIDA.

Det skal understreges, at vaner og rutiner er grundlæggende for alle organisationer - og naturligvis også for de unders $\varnothing$ gte dagtilbud, der repræsenterer den strategiske læringsform. Det, vi sætter analytisk fokus på i midtvejsanalysen, er forskellene mellem de unders $\varnothing$ gte dagtilbud i måden, hvorpå de arbejder med at udvikle og udfordre vaner og rutiner. Her ser vi, at nogle er meget eksplicitte og strategiske, mens andre er mere implicitte og erfaringsbaserede i forhold til retningen og styringen af den pædagogiske praksis og inddragelse af viden. Det bliver i denne sammenhæng interessant at følge de forskellige dagtilbud i forhold til udvikling på baggrund af VIDA-implementeringen og se, i hvor høj grad de forskellige fremmende og hæmmende faktorer påvirker denne implementering.

Med de forbehold, der må tages for det oparbejdede datamateriales repræsentativitet i forhold generelt til dagtilbud, viser analysen, at forskelle, der er sporet i den samlede beskrivelse af arbejdskultur, læring og konkret praksis, relaterer sig til den måde, dagtilbuddet møder udfordringer vilkår på, og generelt vil få betydning for dagtilbuddets potentialer for læring i den samlede organisation. Midtvejsanalysen, der bygger på interview med samtlige VIDA-dagtilbuds ledere, forventes at give gyldig viden om sammenhænge mellem potentialer for læring og den måde, dagtilbuddet mere specifikt forholder sig til og håndterer de opgaver på, som VIDA-programmet samlet set lægger op til. Det kvalitative datagrundlag, der ligger til grund for denne analyse, gør det således muligt at fremsætte en hypotese, der lægger op til yderligere udforskning gennem den videre VIDA-proces. 


\section{VIDA-FORÆLDREINDDRAGELSE}

Interviewene med samtlige ledere, dvs. både ledere fra VIDA-Basis-institutioner og VIDA-Basis +-institutioner, viser, at det, der fra institutionernes side lægges vægt på i forældresamarbejdet, er: (1) at opbygge en åben, gensidig, direkte og anerkendende dialog, fortrinsvis bygget op gennem den daglige kontakt og samtale; (2) hurtig indsats ved observerede udfordringer i trivslen for et enkelt barn og/eller børnegruppen; (3) at der er en fortløbende information omkring, hvad der foregår i institutionen samt (4) en klar og åben forventningsafstemning mellem hjem og institution. Denne del af analysen viser, at forældresamarbejdet om udsatte børn består i at have en dialog, hyppigere forældrem $\varnothing$ der og tværfaglige netværksm $\varnothing$ der. Endvidere består det i at lave arbejdsdage og andre praktiske arrangementer, hvor de udsatte børns forældre opfordres til at deltage. Det sidste er dog stadig snarere et $\varnothing$ nske end gennemf $\varnothing$ rt i de deltagende institutioner. Der er også i nogle daginstitutioner særlige aktiviteter for udsatte familier såsom grupper for mødre og par samt aktiviteter, hvor forældre kan deltage i aktiviteter og samspil med deres barn i institutionen. Disse særlige tiltag findes dog kun i meget få institutioner.

Det beskrives videre i interviewene, at der er bestemte udfordringer mht. at få forældresamarbejdet til at fungere optimalt. Disse udfordringer er hhv. eksterne og interne.

- De eksterne udfordringer omfatter: forældrenes travlhed; forældrenes opprioriteringer af eget barn, som ses som en modsætning til fællesskabet.

- De interne udfordringer omfatter: at nogle medarbejdere har svært ved at udvise en anerkendende holdning - både i ord og i praksis; og at man som medarbejdergruppe kan komme til at bygge videre på hinandens negative opfattelser af bestemte forældre - og derved opbygge en ekskluderende diskurs og praksis.

Mht. mulighederne for at styrke udsatte børns trivsel igennem et godt forældresamarbejde viser analysen, at man gerne vil udbygge ved at (1) opbygge et generelt forældresamarbejde, der er inkluderende over for de udsatte børns forældre; (2) skabe muligheder for de udsatte børns forældre for at indgå i aktiviteter, hvor de kan deltage ligeværdigt, og hvor de har kompetencer til at deltage, fx i praktiske aktiviteter; (3) få muligheder for mere direkte, praktisk vejledning af forældre til udsatte børn enten i institutionen eller i hjemmet og (4) bevare, styrke og videreudvikle medarbejdernes kapacitet til at varetage den anerkendende og løsningsorienterede dialog, der ses som det mest betydningsfulde i samarbejdet med forældre til udsatte børn. 
I analysen træder det tydeligt frem, at det vigtigste i forældresamarbejdet er at kunne skabe den åbne, respektfulde og løsningsorienterede dialog. Da forældregruppen kan komme til at bidrage til eksklusion ved at have meget fokus på deres eget barn og ikke på fællesskabet - og ved i nogle tilfælde at være aktivt stemplende og problemfokuserede omkring bestemte børn (og forældre) i institutionen - er der fokus på daginstitutionens muligheder for at bidrage til at opbygge et forældrefællesskab, der er inkluderende og anerkendende.

Ud over dette ser man samarbejdet med de udsatte børns forældre som et anliggende for daginstitutionens medarbejdere sammen med andre professionelle i de tværfaglige netværk - og forældrene til de udsatte børn. Dette sker gennem $\phi$ get opmærksomhed og endnu mere dialog end med de $\phi$ vrige forældre. Der anvendes en anerkendende og løsningsorienteret dialog - hvilket dog godt kan være en stor udfordring at deltage i for både forældrene og medarbejderne. For at invitere de udsatte børns forældre ind i forældresamarbejdet foreslås det mange steder at opbygge flere forældrearrangementer med et mere praktisk fokus end et blot verbalt. Det er dog stadig en udbredt erfaring, at de udsatte børns forældre kun deltager, hvis de specielt opfordres til dette.

Endvidere kan det konkluderes, at mange af institutionerne ser en udviklingsmulighed i at styrke de udsatte børns forældre i det almene forældresamarbejde og derved skabe en inklusionsproces, der løber som en parallel proces i forhold til inklusionen af de udsatte børn i børnefællesskabet i institutionen. At skabe muligheder for dette bliver set som en udviklingsmulighed i forældresamarbejdet omkring udsatte børn med henblik på at skabe gode muligheder for sund kognitiv, social og emotionel udvikling for alle børnene. Det er netop det, VIDABasis +-uddannelsen lægger op, at daginstitutioner trænes i og arbejder bevidst og målrettet med. Analyser af det videre forl $\varnothing \mathrm{b}$ vil vise, hvilke forældreinddragelsesformer, der faktisk implementeres, og hvordan disse former bliver opfattet af forældrene.

\section{B $\emptyset$ RNS KOMPETENCER - OG SOCIALE FORSKELLE}

Den sidste del af analysen fokuserer på børnenes kompetencegrundlag, som er det, det heler drejer sig om, gennem VIDA-projektets fokus på at styrke også socialt udsatte børns læring og trivsel gennem en fokuseret og målrettet kvalitetsudviklingsindsats. Analysen af sammenhængen mellem karakteristika for daginstitutionerne, især det gennemsnitlige uddannelsesniveau for børnenes mødre, og det enkelte barns kompetencer viser, at det enkelte barns kompetencer er bedre, jo flere veluddannede mødre der har børn i den pågældende daginsti- 
tution. Analysen påpeger videre, at årsagerne kan være trefoldige. Det kan enten skyldes, at veluddannede mødres børn har bedre kompetencer, som forstærker det enkelte barns kompetencer. Det kan også skyldes, at jo flere veluddannede mødre, der har børn i den enkelte institution, jo flere ressourcer kan personalet overføre fra basale pasningsopgaver til egentligt pædagogisk arbejde, og endelig kan det skyldes effekter af uobserverede forhold. Videre forskning i VIDA-projektet vil kaste lys over, hvilke forklaringer der er den/de rigtige.

\section{AFSLUTNING}

De enkelte delelementer, som er beskrevet i denne statusrapport, har til formål dels at gøre midtvejsstatus over VIDA-projektets indhold og fremdrift i forhold til uddannelsens første faser og dels at analysere de tre aspekter af effektanalysen, som vil være gennemgående i hele forlфbet. De tre aspekter omhandler: 1) institutionernes arbejde med implementering af guidelines vedrørende stimulering af børns trivsel og læring ud fra et perspektiv om organisatorisk læring, 2) institutionernes arbejde med implementering af guidelines vedrørende stimulering af børns trivsel og læring gennem nye former for forældreinddragelse, og 3) børns kompetenceudvikling, hvad angår socio-emotionelle kompetencer (trivsel) målt på SDO. I efterfølgende analyser bliver der målt på børns læring vurderet ud fra læringsmål, der knytter sig til pædagogiske læreplaner og inspireret af det engelske studie "Effective Provision in Preschool Education" (EPPE).

Midtvejsanalysen har vist, at VIDA-programmet, som det udfoldes i uddannelsesforlфbet, har gode men også med forskellige forudsætninger for at blive implementeret. Både i de institutioner, der i forvejen arbejder teoribaseret og strategisk målrettet, og i de institutioner, der arbejder mere erfaringsbaseret, er påvist et stort engagement $i$ at højne fagligheden ud fra VIDA-projektets retningslinjer. Udfordringerne består først og fremmest i at arbejde med børn og børnefællesskaber på nye måder og at inddrage den samlede personalegruppe i dette arbejde, så det samlede dagtilbud udvikler en fælles, ny strategi. Dette arbejde med organisatorisk læring udg $\varnothing$ r VIDA-projektets unikke tilgang til at skabe varig fornyelse i de deltagende dagtilbud med tilsigtede positive effekter for de børn, det hele drejer sig om. Det er den organisatoriske læring der både volder de største kvaler for nogle dagtilbud og bibringer andre helt nye 'aha-oplevelser'.

Sammenfattende peger analysen på, at det krav, der ligger i VIDA-perspektivet om organisatorisk læring, på undersøgelsestidspunktet (sommer 2011) var en stor udfordring at forpligte sig på og konkret organisere måder, hvorpå det sam- 
lede dagtilbud kunne arbejde med ny forskningsbaseret viden og omsætte denne sammen med egne erfaringer i innovative strategier i praksis. Midtvejsanalysen vidner om, at dette for mange er krævende - men også at interessen og motivationen for at forandre praksis er til stede.

Opfølgende casestudier (gennemf $\varnothing$ rt i udvalgte institutioner, marts 2012) gennem feltstudier og interview med leder og medarbejdergrupper nuancerer imidlertid billedet. Disse casestudier, som afrapporteres i en senere rapport, bidrager til indsigt i, hvordan udvalgte dagtilbud arbejder målrettet og systematisk med at implementere VIDA-projektets perspektiver og hele ideen om organisatorisk læring. Diversitet i dagtilbuddene indebærer, at processen finder sted med forskelligt tempo og udbytte, men processen er sat i gang, og bes $\varnothing$ gene giver indblik både i en travl hverdag og et engageret personale, der arbejder målrettet og systematisk med en eksperimenterende tilgang.

Forholdet mellem de forskellige læringsformer og grundformer for pædagogisk praksis vil være i fokus for efterfølgende casestudier og vil blive analyseret i efterfølgende rapporter.

Formålet med denne rapport, midtvejs i VIDA-projektet, var at redegфre mere detaljeret for VIDA uddannelsens elementer (fase 1) samt for mere avancerede statistiske analyser af baseline data med afsæt både i kvantitative og kvalitative dataanalyser.

Samlet set viser analysen, at deltagende dagtilbud og kommuner har sat processerne i gang og mange vigtige resultater er allerede fremkommet. Den videre proces både med hensyn til uddannelsens fase 2 -3 og videregående dataindsamlinger og analyser vil sætte fokus på implementeringsprocesser i VIDA og disses effekt. 
VIDENSBASERET INDSATS OVER FOR UDSATTE BøRN I DAGTILBUD 


\section{BILAG}

\section{BILAG 1: MATERIALE TIL KAPITEL 4, AFSNIT 4.2}

Boks 1. Forskellige mødeformer

\section{Code Family: Læringsmetode: Mødet}

Koder: 30

Quotation(s): 83

[2.1 P-weekend med temaer] [2.2 P-dag præsentere ny teori] [2.2 P-møder præsentation og diskussion] [2.2 stuem $\varnothing$ de][2.2 Diskutere inklusion på P-m $\varnothing$ de] [2.2 Personalemøder] [2.2 Pædagogisk dag med tema] [2.2 Refleksionsmøder som videndeling] [2.2 Vi holder oplæg][2.2 Aftenm $\varnothing$ der med temadiskussion] [2.2 Gruppem $\varnothing$ de med formidling fra kursus] [2.2 Holder forskellige typer af møder] [2.2 leder deltager på studem $\varnothing$ der] [2.2 Møde med debat om tema] [2.2 P-møde med diskussion og case] [2.2 P-møde med oplæg] [2.2 Praktiske P-m $\varnothing$ der] [2.2 Pædagogfaglige møder uden medhjælper] [2.2 Tilpasse m $\varnothing$ deaktivitet efter type af viden] [2.4 Personalem $\varnothing$ der med oplæg][2.2 Kursusrapportering ved P-møde] [2.2 oplæg fra ansatte om emne] [2.2 Oplæg med gruppediskussion] [2.2 P-møde med oplæg] [2.2 P-weekend med eksterne oplæg om emne] [2.2 Personalem $\varnothing$ der] [2.2 Plan for næste P-møde] [2.2 præsenterer nyt på m $\varnothing$ der] [2.2 stuem $\varnothing$ de 1/2 time] [2.2 Viden deling: læse og fælles refleksion ved P-møde] 
Boks 2. Kursus, uddannelse og oplæg.

\section{Code Family: Læringsmetode: Kursus, uddannelse og oplæg}

\section{Koder: 27}

Quotation(s): 57

[2.2 Kursusdeltagelse 2 med P-mødeorientering] [2.2 sende ansatte på kursus] [2.2 to afsted på kursus] [2.2 Uddannelsesforløb] [2.2 videndeling gennem kursus] [2.2 Kursusdeltagelse] [2.2 sende folk på uddannelse] [2.2 sender ansatte på kursus] [2.2 Kursusdeltagere laver hæfte de andre kan læse] [2.2 kursus deltagelse hos de uddannede pædagoger] [2.2 Kursus som videndeling] [2.2 Videreuddannelse ny viden ind] [2.2 Eksterne oplægsholdere - viden udefra] [2.2 Inddrager viden udefra] [2.2 opdatere viden] [2.2 Reflekterer oversituationer med konsulent] [2.2 Viden fra kommunekonsulent] [2.2 Ringe for at få viden] [2.2 Specialiseret viden] [2.2 Specialistviden] [2.2 Strategiske oplæg udefra] [2.2 Åben for viden udefra] [2.2 Specifik viden inden for områder] [2.2. Eksterne videnkilder] [2.2 Eksterne holder oplæg] [2.2 Konsulent fra kommunen.

Boks 3. Læse faglitteratur

\section{Code Family: Læringsmetode: Læse faglitteratur}

\section{Koder: 16}

Quotation(s): 40

[2.2 Faglitteratur lægges frem] [2.2 Læse noget faglitteratur] [2.2 Viden deling: læse og fælles refleksion][2.2 Leder lokalisere litteratur og lægger til personale] [2.2 Læser litteratur] [2.2 Ny litteratur ind i møder] [2.2 Ops $\varnothing$ ger relevant viden] [2.2 Alle skal have samme materiale] [2.2 Læse artikel og diskutere] [2.2 Læser faglitteratur] [2.2 Læser VIDA mappe] [2.2 Tilgængeligt materiale] [2.2 Læsning er nøglen] [2.2 Læsning giver ikke mening] [2.2 opdatere viden] [2.2 X-tra timer til at læse] 
Boks 4. Medarbejderinteraktion og netværk

\section{Code Family: Læringsmetode: Medarbejderinteraktion og netværk}

\section{Medarbejderinteraktion}

Koder: 12

Quotation(s): 15

[2.2 Læring fra at gøre projekter sammen] [2.2 medarbejder dreven udvikling] [2.2 bedre læring i små grupper] [2.2 Måden man taler til hinanden på] [2.2 Pædagoger anbefaler selv litteratur] [2.2. Intern videndeling] [2.2 Deler viden fra diskussion i institution] [2.2 Bruger diskussioner] [2.2 Personale underviser hinanden] [2.2 Praksisfortælling] [2.2 Reflektere i personalegruppen] [2.2 Reflektere i situationer med viden]

\section{Netværk}

Koder: 7

Quotation(s): 13

[2.2 Institutionsledernetværk] [2.2 fredagsnetværksmøde udveksling af viden] [2.2 fusion med andre fagligheder] [2.2 netværk] [2.2 netværkssamarbejde eksternt i kommune] [2.2 Bruger netværk] [2.2 netværk] 
Boks 5. Struktureret læringsform

\section{Code Family: Læringsmetode: Organisering og lederstyring}

\section{Lederstyring og organisering \\ Koder: 39 \\ Quotation(s): 57}

[2.2 Introdag for nye ansatte] [2.2 ledelsesopgaven skal være skarp] [2.2 Leder filtrerer viden for medarbejdere][2.2 Lederen skal facilitere] [2.2 Virksomhedsplan beskriver hvordan vi arbejder med viden] [2.2 Bruger sin egen motivation til at smitte de andre] [2.2 leder deltager på studem $\phi$ der] [2.2 Leder er tovholder] [2.2 Leder lokalisere litteratur og lægger til personale] [2.2 Leder lokaliserer viden] [2.2 Leder styrer hvad skal læses - ligger det frem] [2.2 Opsøger relevant viden] [2.2 Stuegang og dialog med personale] [2.2 Tydelig og tidlig kommunikation om nyt til personalet] [2.2 Drømmer om at gøre viden deling mere strategisk][2.2 bedre læring i små grupper] [2.2 Behovsdrevet udvikling] [2.2 Evaluering i fokus: tydeliggrelse] [2.2 Hjemmearbejde f $\varnothing$ r P-m $\varnothing$ de] [2.2 Leder lokalisere litteratur og lægger til personale] [2.2 Målrettet udvikling] [2.2 Opfølgning og monitorering] [2.2 organisering og struktur] [2.2 Praktisere ny viden $=$ mere bevidste om det] [2.2 Rotationsprojektet] [2.2 Specifik viden inden for områder] [2.2 Strategiplan for udviklingen] [2.2 Strategisk kompetenceudvikling] [2.2 Struktur for videndeling FYRTÅRNE] [2.2 Struktur på U forl $\varnothing \mathrm{b}$ ] [2.2 Tilpasse mødeaktivitet efter type af viden] [2.2 viden ind v. nyansatte e.g. praktikanter] [2.2 Ind med viden fra studerende o.a.=læringsrum] [2.2 MUS samtale som instrument] [2.2 Organisere sig for at inddrage ny viden] [2.2 Organisering=handleplaner] [2.2 Organisering=statusm $\varnothing$ der] [2.2 Organisering=Årsplaner] [2.2 Strategisk kompetenceudvikling]

\section{BILAG 2: MEDARBEJDERINTERAKTION OG NETVÆERK}

\begin{tabular}{|l|c|l|c|c|}
\hline Kommune & \multicolumn{1}{|c|}{$\mathbf{Y}$} & \multicolumn{1}{|c|}{ E } & \multicolumn{1}{|c|}{$\mathbf{Z}$} & $\mathbf{X}$ \\
\hline Medarbejderinteraktion & 5 citater & 7 citater & 1 citater & 3 citater \\
\hline Netværk & 6 citater & 5 citater & 1 citater & 1 citater \\
\hline
\end{tabular}




\section{BILAG 3: FREMMENDE OG H/EMMENDE FAKTORER}

\begin{tabular}{|c|c|c|}
\hline $\begin{array}{l}\text { Pædagogiske } \\
\text { praksisser }\end{array}$ & Faktorer af betydning & $\begin{array}{l}\text { Eksempler fra VIDA } \\
\text { interview }\end{array}$ \\
\hline $\begin{array}{l}\text { Teoribaseret læringstil- } \\
\text { gang } \\
\text { (i alt } 24 \text { institutioner) }\end{array}$ & $\begin{array}{l}\text { Ydre: } \\
\text { Ressourcer } \\
\text { Uddannelse } \\
\text { Normering } \\
\text { Opgaver } \\
\text { Rammer } \\
\text { Struktur } \\
\text { Besparelser } \\
\text { Børnesammensætning } \\
\text { Meget sygdom, uro } \\
\text { Æstetikken } \\
\text { Teknik der svigter } \\
\text { Tværfagligt samarbejde } \\
\text { svært } \\
\text { Indre: } \\
\text { Refleksioner over børns } \\
\text { fremtid } \\
\text { Faglighed } \\
\text { Ælldre pædagoger } \\
\text { Personalets moral, etik, } \\
\text { adfærd } \\
\text { Forskelle på personalets } \\
\text { forskellige strategier } \\
\text { Professionens 'habitus' } \\
\text { Pædagoger for ambitiøse } \\
\text { At få personalet til at se } \\
\text { på egen praksis, at turde } \\
\text { blive set, sætte tryghed } \\
\text { på spil } \\
\text { Ikke alle i personalegrup- } \\
\text { pen man kan få med, } \\
\text { mange 'gråhårede' }\end{array}$ & $\begin{array}{l}\text { Pos forventninger: } \\
\text { Sætter en videnskabelig } \\
\text { og akademisk dagsorden } \\
\text { Bygger videre på det vi er } \\
\text { i gang med } \\
\text { En øjen-åbner } \\
\text { Vi bliver bevidst om at } \\
\text { udforske os selv } \\
\text { Skærper opmærksomhe- } \\
\text { den på læring og didaktik } \\
\text { Personalet bliver mere } \\
\text { modigt } \\
\text { Fedt at det ikke er en 'fær- } \\
\text { dig metode' } \\
\text { VIDA har givet meget } \\
\text { allerede } \\
\text { Kan hjælpe os til at grave } \\
\text { et spadestik dybere i fag- } \\
\text { ligheden } \\
\text { Kan hjælpe mig til at } \\
\text { blive en dygtigere leder, } \\
\text { giver redskaber } \\
\text { Glad for at være med } \\
\text { Fint supplement til egne } \\
\text { planer } \\
\text { Lærer ledelsesstrategier } \\
\text { At få debatten hævet op } \\
\text { over praksis } \\
\text { Sætter dialog i gang } \\
\text { Skepsis } \\
\text { Kan gøre en forskel, men } \\
\text { ikke lige i dag (ikke alle } \\
\text { i personalegruppen kan } \\
\text { man få med) }\end{array}$ \\
\hline
\end{tabular}




\begin{tabular}{|c|c|c|}
\hline $\begin{array}{l}\text { Erfaringsbaseret lærings- } \\
\text { tilgang } \\
\text { (i alt } 19 \text { institutioner) }\end{array}$ & $\begin{array}{l}\text { Ydre: } \\
\text { Besparelser } \\
\text { Faglighed } \\
\text { Uddannet personale } \\
\text { Normeringer, фkonomi } \\
\text { Bevillinger svigter } \\
\text { Tid, presset } \\
\text { Politiske trends } \\
\text { Nuancer forsvinder } \\
\text { Fysiske rammer } \\
\text { Krav oppefra } \\
\text { Børnegruppen } \\
\text { Indre: } \\
\text { Arbejdspladskulturen } \\
\text { svær at vende, vaner } \\
\text { Organisering svær } \\
\text { Personalet synes det er } \\
\text { svært } \\
\text { Personalet forklarer i } \\
\text { stedet for at handle } \\
\text { 'Jammermåtten længe } \\
\text { nok' }\end{array}$ & $\begin{array}{l}\text { Positiv } \\
\text { Det vil } \varnothing \text { ge fagligheden } \\
\text { Bevidstheden } \varnothing \text { ges } \\
\text { Ikke godt nok at gøre som } \\
\text { vi selv har lyst til, stort at } \\
\text { arbejde forskningsbaseret } \\
\text { Kvaliteten højnes } \\
\text { Godt med } \varnothing \text { get faglighed } \\
\text { Bidrager med et lærings- } \\
\text { begreb } \\
\text { Mere opmærksomme, } \\
\text { refleksion højnes } \\
\text { Vi får hjælp gennem } \\
\text { VIDSA, det er nogle rigtig } \\
\text { fede begreber } \\
\text { Falder lige ned i vores } \\
\text { kurv } \\
\text { Vi er allerede blevet mere } \\
\text { bevidste, ingen tvivl om } \\
\text { at det vil gøre en forskel } \\
\text { Godt at få redskaber til at } \\
\text { kortlægge forskelligheder } \\
\text { i personalegruppen } \\
\text { Skepsis } \\
\text { VIDA ikke nyt } \\
\text { Vigtigt at få det formidlet, } \\
\text { stor udfordring } \\
\text { Redskaber, materialer er } \\
\text { en eye-opener, ikke no- } \\
\text { get der sker 'over night' } \\
\text { (personalet synes det er } \\
\text { svært), men om } 4 \text { år er det } \\
\text { integreret } \\
\text { Jeg er ikke den store teo- } \\
\text { retiker men får ting til at } \\
\text { virke, vi laver vores egen } \\
\text { pædagogik, bruger ikke } \\
\text { andres - så vi får se med } \\
\text { VIDA }\end{array}$ \\
\hline
\end{tabular}




\begin{tabular}{|c|c|c|}
\hline $\begin{array}{l}\text { Behovsbaserede tilgang } \\
\text { (i alt } 22 \text { institutioner) }\end{array}$ & 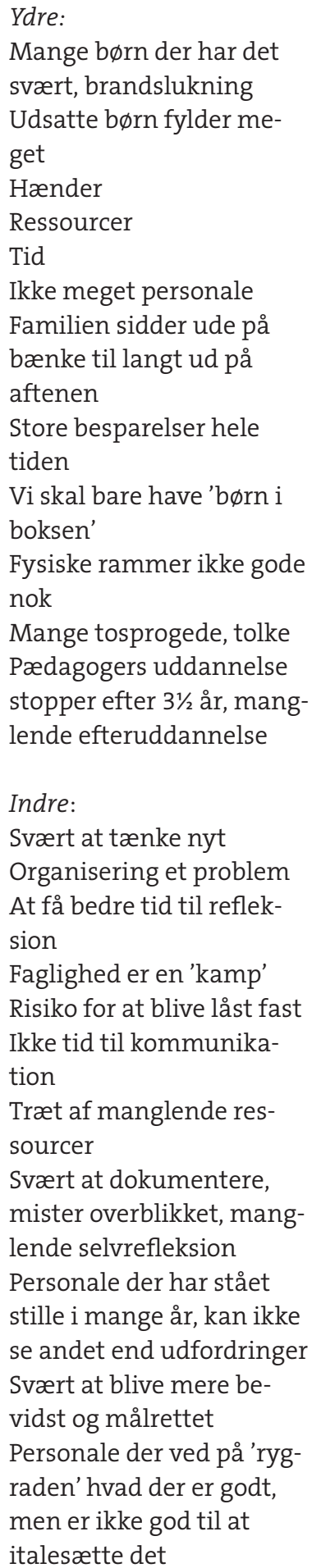 & $\begin{array}{l}\text { Positiv } \\
\text { Store forventninger til at } \\
\text { det vil kunne forandre } \\
\text { verden } \\
\text { Vi kan få hjælpe til bedre } \\
\text { at udnytte kompeten- } \\
\text { cerne } \\
\text { En } \varnothing \text { jenåbner } \\
\text { At vi kan få viden i spil } \\
\text { At vi bliver gode til at } \\
\text { reflektere } \\
\text { At det sætter gang i vores } \\
\text { faglighed } \\
\text { Med VIDA har vi forstået } \\
\text { vigtigheden af at kom- } \\
\text { munikere } \\
\text { Det ændrer vores tanke- } \\
\text { gang } \\
\text { Vi har snakket meget } \\
\text { pædagogik i forbindelse } \\
\text { med projektet } \\
\text { Det har givet rigtig meget, } \\
\text { håber jeg kan få det søsat } \\
\text { i hele institutionen } \\
\text { Vi lærer at reflektere over } \\
\text { hvorfor vi gør tingene } \\
\text { Håber VIDA kan } \emptyset g e ~ f a g-~ \\
\text { ligheden og bidrage til en } \\
\text { bedre dialog i personale- } \\
\text { gruppen } \\
\text { VIDA uddannelsen er } \\
\text { simpelt hen så god }\end{array}$ \\
\hline
\end{tabular}


VIDENSBASERET INDSATS OVER FOR UDSATTE BøRN I DAGTILBUD 


\section{REFERENCER}

Aizer, A. (2008). Peer effects and human capital accumulation: the externalities of $A D D$, NBER working paper 14354.

Ammermueller, A., \& J. Pischke (2009) Peer Effects in European Primary Schools: Evidence from the progress in International Reading Literacy Study, Journal of Labor Economics, 27(3), 315-341.

Bens, I. (2006). Facilitating to lead! Leadership strategies for a networked world. San Francisco: Jossey-Bass.

Bligh, D.A. (2000). What's the use of lectures? 6th edn. San Francisco: Jossey-Bass. Bransford, J.D., Brown, A.L., \& Cocking, R.R. (eds).(2000). How people learn: Brain, mind, experience, and school. Committee on Learning Research and Educational Practice, Commission on Behavioral and Social Sciences and Education. Washington, D.C.: National Academy Press.

Christensen, P.H. (2007). Motivation i videnarbejde. København: Hans Reitzel.

Damgaard, I. (2000). Den personlige samtale. København: Hans Reitzel.

Green, A. \& Mostafa, T. (2011). Pre-School Education and Care - A 'Win-Win' Policy?, LLAKES Research Paper 32, University of London. LLAKES Research Paper 32, University of London (www.llakes.org/llakes-research-papers).

Goldstein, H. (2010), Multilevel Statistical Models, 4. edition, Wiley.

Haworth, C, Asbury,K., Dale, P., \& Plomin, R. (2011). Added Value Measures in Education Show Genetic as Well as Environmental Influence, PLOS ONE, Vol. $6(2)$.

Heckman, J.J. (2008). Schools, Skills and Synapses. NBER Working Paper No. 14064. Economic Inquiry, Western Economic Association International, 46(3), 289-324.

Heckman, J.J., Moon, S.H., Pinto, R., Savelyev, P., \& Yavitz, A. (2010). Analyzing social experiments as implemented: a re-examination of the evidence from the High/scope Perry Preschool. Quantitative Economics, 1(1), 1-46. 
Hogan, C. (2003b). Understanding facilitation: Theory and principles. London: Kogan Page.

Hunter, D. (2009). The art of facilitation. New York: Wiley.

Høyrup, S., Pedersen, K., Rattleff, P., og Wahlgren, B. (2002). Refleksion og læring. København: Samfundslitteratur.

Jensen, B., Holm, A., Wang, C., Kousholt, D., Ravn, I., Søgaard Larsen, M., Steiner Rasmussen, O., Berliner, B., Yung Andersen, T., \& Brandi, U. (2011 a). Vidensbaseret indsats over for udsatte børn i dagtilbud -modelprogram. Statusrapport 1. Design og metode. I: VIDA-forskningsserien 2011:01, DPU, Aarhus Universitet.

Jensen, B., Brandi, U., Kousholt, D., Berliner, B., Yung Andersen, T., Hellmund, G., \& Holm, A. (2011b). Vidensbaseret indsats over for udsatte børn i dagtilbud -modelprogram. Statusrapport 2. Baseline. I: VIDA-forskningsserien 2011:03, DPU, Aarhus Universitet.

Jensen, B., Brandi, U. \& Haarh-Pedersen, J. (2011c). VIDA-projektet. Vidensbaseret indsats over for social udsatte børn i dagtilbud med forældreinddragelse. VIDA-Kvalifikationsmappen 2010-2012. Frederikshavn: Dafolo (ikke offentliggjort VIDA-undervisningsmateriale).

Jensen, B \& Haarh-Pedersen (2011). VIDA-projektet. Vidensbaseret indsats over for socialt udsatte børn i dagtilbud med forældreinddragelse. Tillæg til Kvalifikationsmappen 2010 - 2012. Dafolo (ikke offentliggjort materiale).

Jensen, B., Holm, A., \& Bremberg, S. (2011). The Effects of an Inclusive ECEC. Intervention Program on Child Strengths and Difficulties. CSER WP No. 0009. Working paper Series. Centre for Strategic Educational Research, DPU, Aarhus University.

Jensen, B., Holm, A., Allerup, P., \& Kragh, A. (2009). Effekter af indsatser for socialt udsatte børn i daginstitutioner. HPA-projektet. København: Danmarks Pædagogiske Universitetsforlag.

Jensen, B. et al. (2009). Handlekompetencer i pædagogisk arbejde med socialt udsatte børn og unge - indsats og effekt. HPA-projektet - en sammenfatning. Danmarks Pædagogiske Universitetsforlag.

Kousholt, D. (2011). Børnefællesskaber og familieliv: Børns hverdagsliv på tværs af daginstitution og hjem. København: Dansk Psykologisk Forlag.

Lavy, V., Silva,O. \& Weinhardt, F. (2012). The Good, the Bad, and the Average: Evidence on Ability Peer Effects in Schools, Journal of Labor Economics, Vol. 30, No. 2, pp. 367-414.

Manski, C. (1993). Identification of Endogenous Social Effects: The Reflection Problem, The Review of Economic Studies, Vol. 60(3), 531-542. 
March, H. (1985). Age and sex effects in multiple dimensions of preadolescent self-concept: A replication and extension. Australian Journal of Psychology, 37(2), 192-204.

Neidell, M. og J. Waldfogel (2010). Cognitive and Noncognitive Peer Effects in Early Education, The Review of Economics and Statistics, August 2010, 92(3):562-576.

Nielsen, A.A. \& Nygaard Christoffersen, M. (2009). B $\varnothing$ rnehavens betydning for b $\varnothing$ rns udvikling. En forskningsoversigt. København. Det Nationale Forskningscenter for velfærd. SFI 09:27.

OECD (2012). Starting Strong.III: Quality Toolbox for Early Childhood Education and Care. OECD: Directorate for Education.

Ravn, I., og Rokkjær, J. (2006). Elsam/Nesa skabte mere effektive møder. Rapport fra et træningsforl $\varnothing b$ med Learning Lab Denmark 2005-2006. Learning Lab Denmark, 11. september.

Ravn, I. (2007). The learning conference. Journal of European Industrial Training, 31(3), 212-222.

Ravn, I. (2011a). Facilitering: Ledelse af møder der skaber værdi og mening. Hans Reitzel.

Ravn, I. (2011b). Facilitating learning at conferences. International Journal of Learning and Change, 5(1), 84-98, 2011.

Ravn, I. (2012). What may meeting chairpersons learn from group facilitators? (submitted for conference presentation).

Schneeweiss, N. og R. Winter-Ebmer (2007), Peer effects in Austrian schools, Empirical Economics, 32:387-409.

Socialministeriet (2004). Bekendtgørelse af lov om social service. LBK nr. 708 af 29/06/2004Serviceloven, København: Socialministeriet.

Socialministeriet (2011). Dagtilbudsloven. Lov om dag-, fritids-og klubtilbud mv. til børn og unge, LBK nr 668 af 17/06/2011. https://www.retsinformation. $\mathrm{dk} /$ forms/r0710.aspx?id=137202\&exp=1

Socialstyrelsen (1979). Kollektiver: Ledelse, administration, pædagogik. Rapport om fors $\phi \mathrm{g}$ med kollektiv ledelse af daginstitutioner. Kфbenhavn.

Søgaard Larsen, M., Bang-Olsen, A., Berliner, P., Bjørnoy Sommersel, H., Grosen Pedersen, A., Holm, A. Jensen, B., Müller Kristensen, R., Ploug, N., \& Neriman Tiftikci. (2011). Programmer for 0-6 årige med forældreinvolvering i dagtilbud. En forskningskortlægning. VIDA-forskningsserien 11:02. www.dpu.dk/ vida. og Frederikshavn: Dafolo.

Søgaard Larsen, M., Berliner, P., Holm, A., Jensen, B., \&, Ploug, N. (2012). Parental involvement in effective early interventions for at risk children - a systematic review (Working Paper). 
Søgaard Larsen, M. \& B. Jensen, I. Johansson, T., Moser, N., Ploug, N., og D. Kousholt (2009). Forskningskortlægning af skandinavisk forskning i året $2009 i$ institutioner for de 0-6 årige. Clearinghouse-Forskningsserien.

Tennant, M. (1999). Is learning transferable? In D. Boud \& J. Garrick (Eds.), Understanding learning at work. London: Routledge.

Wahlgren, Bjarne (2009). Transfer mellem uddannelse og arbejde. København: Nationalt Center for Kompetenceudvikling. 


\section{PRAESENTATION AF RAPPORTENS FORFATTERE}

\section{Bente Jensen}

Lektor, ph.d., Aarhus Universitet, og projektleder for VIDA-projektet. Var projektleder på det forudgående HPA-projekt (2005-2009). Har gennem flere år deltaget i forskerteam med fokus på social ulighed, in- og eksklusionsmekanismer fra børns tidligste alder i dagtilbud. Har deltaget i bl.a Forskningsprogrammet om Social Arv (SFI). Er medlem af forskningsprogrammet 'Organisation og læring' ved Institut for Uddannelse og Pædagogik og er en del af den gruppe, der forsker i forholdet mellem læring og innovation.

\section{Ulrik Brandi}

Lektor, ph.d., ved Institut for Uddannelse og Pædagogik, Aarhus Universitet med særligt henblik på læring i organisationer og arbejdspladser og innovation. Han er medlem af forskningsprogrammet 'Organisering og læring' ved Institut for Uddannelse og Pædagogik og er her en del af den gruppe, som forsker i forholdet mellem læring og innovation.

\section{Dorte Kousholt}

Lektor, ph.d., ved Institut for Uddannelse og Pædagogik, Aarhus Universitet. Forsker i familieliv og familiearbejde med fokus på bl.a. forældresamarbejde i dag- og d $\varnothing$ gninstitutioner og fællesskaber i børns liv. Bl.a. forfatter til artikler om børns hverdagsliv på tværs af daginstitution og familie og forældreperspektiver på samarbejde mellem daginstitution og hjem.

\section{Peter Berliner}

Professor MSO, ved Institut for Uddannelse og Pædagogik, Aarhus Universitet. Forsker i sociale lærings- og udviklingsprocesser med særligt henblik på helende læring i samfund, der på grund af katastrofer eller anden nedbrydelse oplever en fragmentering af sociale strukturer og st $\varnothing$ ttesystemer. Deltager i et internationalt forskningssamarbejde om resiliens. 


\section{Ib Ravn}

Lektor, Institut for Læring, ved Institut for Uddannelse og Pædagogik, Aarhus Universitet. Deltager i forskningsprogrammet Organisation og Læring. Ph.D. fra Wharton School of Business ved University of Pennsylvania og B.Sc. fra City University, London. Har tidligere arbejdet som forlagsredaktør, forskningsadministrator og proceskonsulent.

\section{Anders Holm}

Anders Holm er professor, Aarhus Universitet. Han beskæftiger sig med evidensbaseret uddannelsesforskning med særlig vægt på social arv, og hvad der motiverer forskellige befolkningsgrupper til at uddanne sig. Denne forskning tager udgangspunkt $\mathrm{i}$ kvantitative metoder og avancerede statistiske analyser.

\section{Karen Stougaard}

Lektor, ved University College Lillebælt. Beskæftiger sig med uddannelse inden for specialpædagogik, psykologi og social inklusion. Er autoriseret psykolog og har tidligere arbejdet med terapi, konsultativ bistand, udrednings- og interventionsopgaver.

\section{Kristina Kristoffersen}

Adjunkt ved University College Nordjylland. Underviser på diplomuddannelserne indenfor det pædagogisk psykologiske felt og som underviser og proceskonsulent på skoler og dagtilbud og i diverse udviklingsprojekter. Er desuden projektleder for LP-modellen dagtilbud.

\section{Margit M. Nielsen}

Lektor ved University College Nordjylland. Underviser på pædagogiske diplomuddannelser i bla. inklusion og specialpædagogik. Arbejder med programmerne ICDP relations - og ressourceorienteret pædagogik samt LP-modellen, hvor hun deltager i opgaven med at udvikle og gennemføre modellen i dagtilbud for 0-6 årige.

\section{Mette Kristensen Rasmussen}

Adjunkt UC Syddanmark, Campus Aabenraa. Mette er uddannet cand.pæd. i generel pædagogik. Hun underviser på pædagoguddannelsen i pædagogik og i efter- og videreuddannelsen på praktikvejlederuddannelsen. 


\section{Ove Steiner Rasmussen}

Lektor i almen pædagogik og ansat ved UC Syddanmark, Campus Åbenrå. Har i mange år arbejdet med professions- og organisationsudvikling i dagtilbud og SFO. Nøgleordene er systematik, fordybelse, fokusering, opmærksomhed, læring og ned med tempoet! Udviklingspædagogikken har fokus på at forstå og udvikle barnets tanker. Det er udgangspunktet for institutionens opdragelses- og dannelsesopgave.

\section{Mette Friis-Hansen}

Mette Friis-Hansen er Cand. pæd. soc. og ansat ved Institut for Uddannelse og Pædagogik, Aarhus Universitet. Hun er forskningsassistent og tilknyttet to projekter, herunder projektet: "Vidensbaseret indsats overfor udsatte $b \varnothing \mathrm{rn}$ i dagtilbud-modelprogram" (VIDA). 


\section{VIDA}

\section{Vidensbaseret indsats over for udsatte børn i dagtilbud - modelprogram. Statusrapport 3. Midtvejsanalyser}

Statusrapporten gør status over projektet Vidensbaseret indsats over for udsatte børn i dagtilbud (VIDA) og sætter fokus på forhold vedrørende VIDA-uddannelsens første fase og lederkurser rettet imod facilitering af møder og læreprocesser i de deltagende dagtilbud. Der arbejdes i dagtilbuddene med fornyelse af den pædagogiske praksis i et perspektiv om organisatorisk læring og nye former for forældresamarbejde.

Rapporten belyser dagtilbuddenes pædagogiske praksis ved afslutningen af første uddannelsesforl $\varnothing \mathrm{b}$ (sommer 2011) og ledernes beretninger om potentialer i implementering af VIDA-programmet. Endvidere belyses dagtilbuddenes arbejde med forældreinddragelse. Endelig præsenteres mere nuancerede analyser vedrørende deltagende 3-6-årige børns karakteristika, hvad angår kognitive og non-kognitive kompetencer knyttet til deres sociale baggrund samt børnegruppens sammensætning.

Rapporten er udarbejdet som en del af VIDA-forskningsserien knyttet til projektet "Vidensbaseret indsats over for udsatte børn i dagtilbud - modelprogram", som er bestilt og finansieret af Ministeriet for B $\varnothing$ rn og Undervisning og udviklet af forskere ved Aarhus Universitet, Institut for Uddannelse og Pædagogik. Projektet skal udvikle, afprøve og dokumentere hvilke pædagogiske indsatser i dagtilbud, der kan sikre udsatte børn en bedre tilværelse. En vej til at nå dette mål går over kvalificering af professionelle til at implementere VIDA-programmet i det samlede dagtilbud samt til at evaluere og reflektere over proces og resultat.

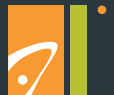

Lillebaelt

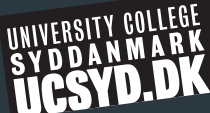

INSTITUT FOR UDDANNELSE OG PAEDAGOGIK AARHUS UNIVERSITET

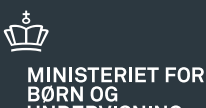

BøRN OG

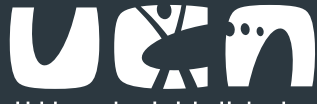

Uddannelse i virkeliaheden

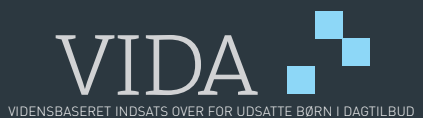

